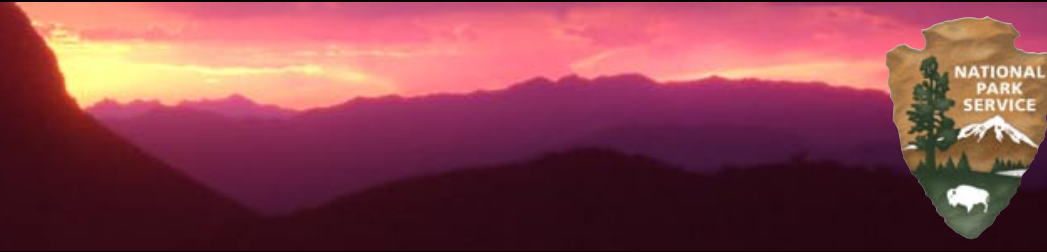

In Cooperation with the University of Arizona, School of Natural Resources

\title{
Vascular Plant and Vertebrate Inventory of Organ Pipe Cactus National Monument
}

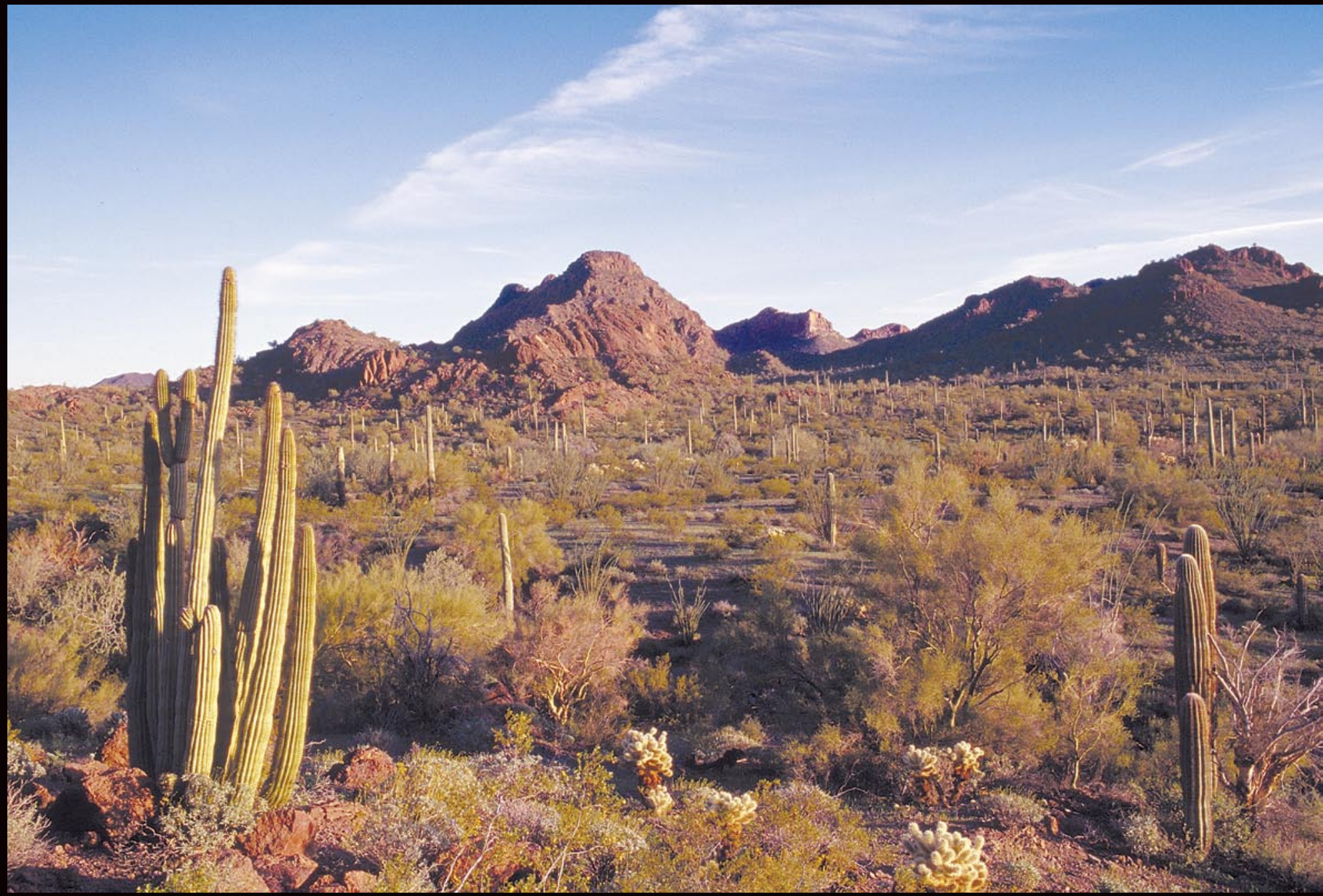

Southwest Biological Science Center

Open-File Report 2006-1076

March 2007

U.S. Department of the Interior

U.S. Geological Survey

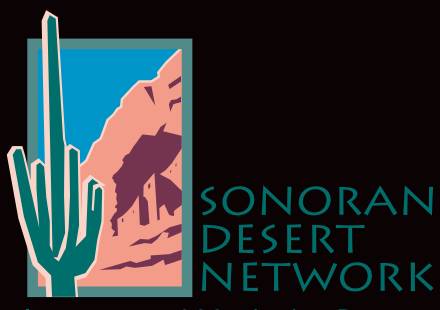

National Park Service 



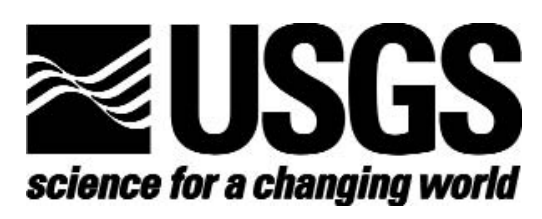

In cooperation with the University of Arizona, School of Natural Resources

\section{Plant and Vertebrate Inventory of Organ Pipe Cactus National Monument}

By Cecilia A. Schmidt, Brian F. Powell, and William L. Halvorson

Open-File Report 2006-1076

March 2007

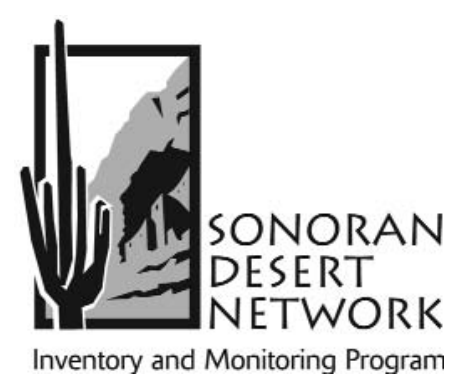

U.S. Geological Survey Southwest Biological Science Center Sonoran Desert Research Station University of Arizona

U.S. Department of the Interior

U.S. Geological Survey

National Park Service School of Natural Resources 125 Biological Sciences East Tucson, Arizona 85721 


\section{U.S. Department of the Interior \\ DIRK KEMPTHORNE, Secretary}

\section{U.S. Geological Survey}

Mark Myers, Director

U.S. Geological Survey, Reston, Virginia: 2007

For product and ordering information:

World Wide Web: http://www.usgs.gov/pubprod

Telephone: 1-888-ASK-USGS

For more information on the USGS - the federal source for science about the Earth, its natural and living resources, natural hazards, and the environment:

World Wide Web: http://www.usgs.gov

Telephone: 1-888-ASK-USGS

\section{Suggested Citation}

Schmidt, C. A., B. F. Powell, and W. L. Halvorson. 2007. Vascular Plant and Vertebrate Inventory of Organ Pipe Cactus National Monument. USGS Open-File Report 2006-1076. U.S. Geological Survey, Southwest Biological Science Center, Sonoran Desert Research Station, University of Arizona, Tucson, AZ.

Cover photo: Organ Pipe Cactus National Monument. Photograph by Brian Powell.

Any use of trade, product, or firm names is for descriptive purposes only and does not imply endorsement by the U.S. Government. 


\section{Authors}

Cecilia A. Schmidt and Brian F. Powell

School of Natural Resources

125 Biological Sciences East, Building 43

The University of Arizona

Tucson, AZ 85721

William L. Halvorson

USGS SBSC Sonoran Desert Research Station

125 Biological Sciences East, Building 43

The University of Arizona

Tucson, AZ 85721

\section{U.S. Geological Survey SBSC Sonoran Desert Research Station Personnel}

Charles van Riper III, Station Leader

William L. Halvorson, Research Ecologist

Cecil R. Schwalbe, Ecologist

Michael R. Kunzmann, Ecologist (Emeritus)

Kathryn Thomas, Ecologist

Pamela Nagler, Physical Scientist

Phil Rosen, Ecologist

\section{Program and Expertise Areas of USGS and UA Personnel}

Administration \& Outreach

Cori Dolan

Jennifer Meador

Wendy Parrish

Emily Sherbrooke

Charles van Riper III

Avian Ecology

Claire Crow

Glenn Johnson

Chris O'Brien

Brian Powell

Charles van Riper III

Data Management

Brent Sigafus

Ecology of Amphibians \& Reptiles

Kevin Baker

Cristina Jones

Dave Prival

Phil Rosen

Cecil Schwalbe

Brent Sigafus
Fire Management

Dennis Suhre

Cori Dolan

Bill Halvorson

Invasive Species Research

Patricia Guertin

Jim Malusa

Phil Rosen

Cecil Schwalbe

Brent Sigafus

Dennis Suhre

Kathryn Thomas

Inventory \& Monitoring

Patricia Guertin

Bill Halvorson

Pamela Nagler

Brian Powell

Cecilia Schmidt

Vegetation Mapping \& Ecology

Patricia Guertin

Bill Halvorson

Jim Malusa

Kathryn Thomas 


\section{Table of Contents}

Acknowledgements .......................................................................................................................................................

Executive Summary ..................................................................................................................................................

Chapter 1: Introduction and Overview of Ecological Research and Monitoring at

Organ Pipe Cactus National Monument ....................................................................................................1

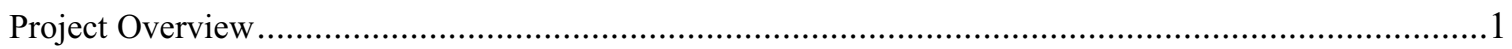

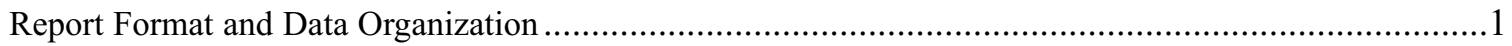

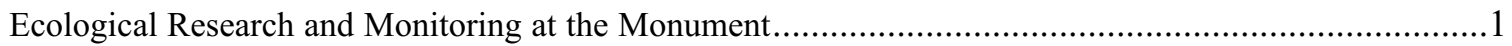

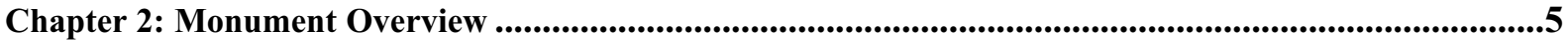

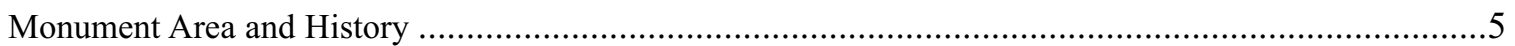

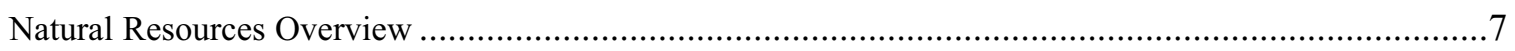

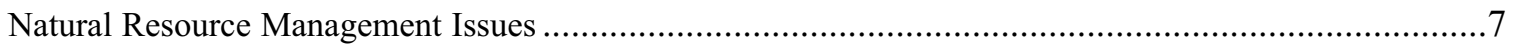

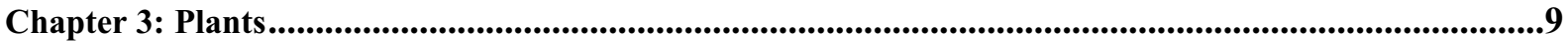

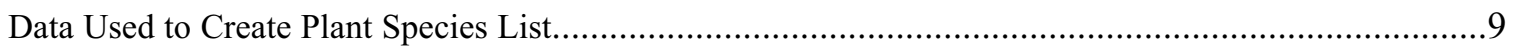

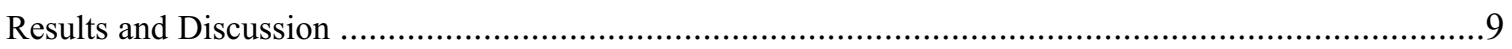

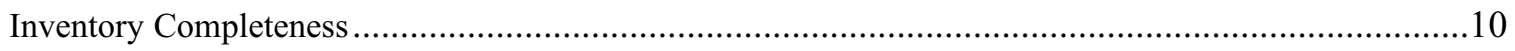

Chapter 4: Amphibians and Reptiles .............................................................................................................11

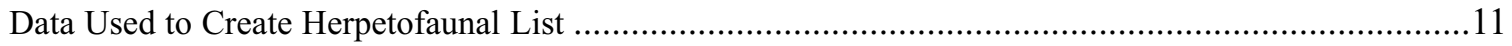

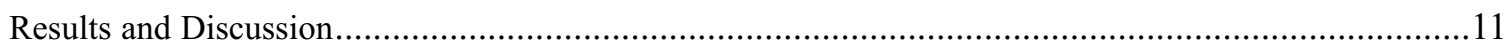

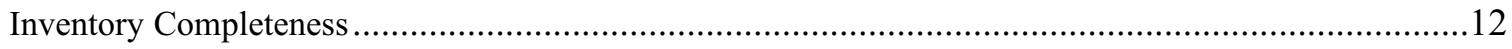

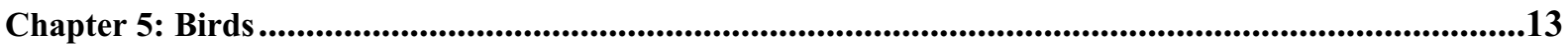

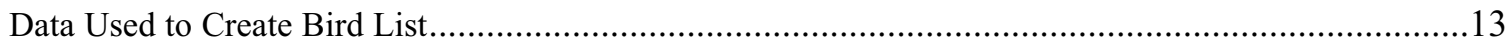

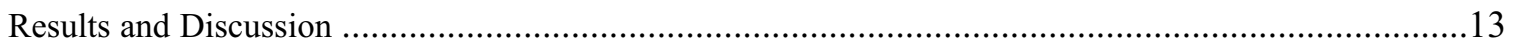

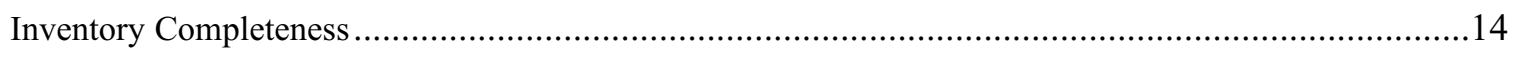

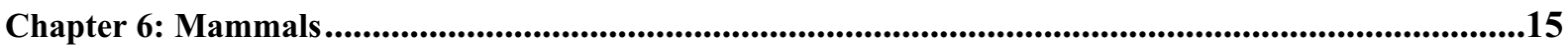

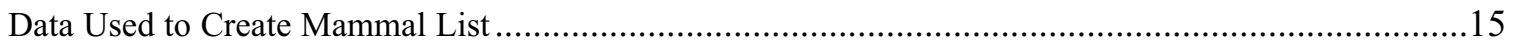

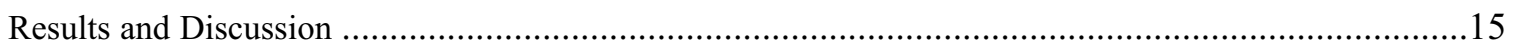

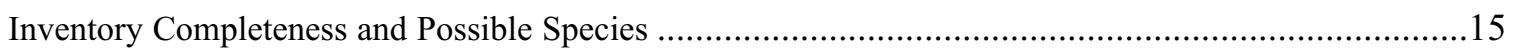

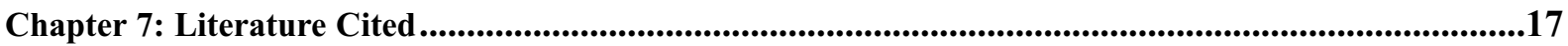




\section{List of Tables}

Table 1. Summary results of vascular plant and vertebrate inventories at Organ Pipe Cactus NM..................ix

Table 1.1. Museums that were queried (in 1998) for vertebrate voucher specimens with "Arizona" and "Organ Pipe Cactus National Monument" in the collection location.......................................2

Table 1.2. Components of the Organ Pipe Cactus National Monument Ecological Monitoring

Program (EMP).

Table 2.1. Average monthly climate data for Organ Pipe Cactus National Monument, 1948-2004. 7

\section{List of Figures}

Figure 2.1. Diagram of major ecological provinces of the southwestern United States and northwestern Mexico.

Figure 2.2. Location of Organ Pipe Cactus NM in relation to other parks in the Sonoran Desert Network of parks.

Figure 2.3. Map of Organ Pipe Cactus NM showing topography and neighboring land ownership. .6

\section{List of Appendices}

Appendix A. Plant species that have been observed or collected at Organ Pipe Cactus NM based on the list by Rutman (2005):

Appendix B. Amphibian and reptile species recorded at Organ Pipe Cactus NM based on list by Rosen and Lowe (1996) and voucher specimens ( Appendix F).

Appendix C. Bird species recorded at Organ Pipe Cactus NM based on lists by Groschupf et al. (1988; Gros), Tibbitts and Dickson (2005; T\&D), and Benson et al. (2001; BE).

Appendix D. Mammal species recorded at Organ Pipe Cactus NM based on list by Cockrum and Petryszyn (1986; C\&P), the Organ Pipe Cactus National Monument Ecological Monitoring Program (NPS 1998a and b; EMP), and voucher specimens (Appendix F).

Appendix E. Amphibian, reptile, and mammal species that may occur at Organ Pipe Cactus NM based on Rosen and Lowe (1996) and Cockrum and Petryszyn (1986).

Appendix F. Known vertebrate voucher specimens from Organ Pipe Cactus NM 


\section{Acknowledgements}

Thanks to Organ Pipe Cactus NM Superintendent Kathy Billings, Chief of Resources Mary Kralovec and all the staff at Organ Pipe Cactus National Monument for their support of our program. This project resulted from the collaboration of many people at the National Park Service, and was facilitated by the Desert Southwest Cooperative Ecosystem Studies Unit (CESU). Andy Hubbard and Larry Norris (NPS) provided administrative support for the project. Additional administrative support was provided by Cecily Westphal of the School of Natural Resources at the University of Arizona.

This report summarizes numerous research projects over the last 75 years. More recently, a number of people have been instrumental in collecting data in the monument and helping us gather data for this report including: Dennis Casper, Charles Connor, Peter Holm, Ami Pate, Sue Rutman, and Tim Tibbitts. Richard Felger and Sue Rutman have been stalwart keepers and revisers of the plant list and we are grateful for their diligence and years of hard work. Philip Rosen and Charles Lowe deserve much of the credit for the amphibian and reptile list. Debbie Angell, Pamela Anning, and Ryan Reese assisted with data entry and database design for this project. Theresa Mau-Crimmins allowed us to use figures 2.1-2.3. We received helpful reviews of an earlier draft of the report from: Charles Connor, Peter Holm, Andy Hubbard, Mary Kralovec, Larry Laing, Theresa Mau-Crimmons, Larry Norris, Sue Rutman, and Tim Tibbitts. All mistakes or omissions are the responsibility of the authors. 


\section{Executive Summary}

We summarized inventory and monitoring efforts for plants and vertebrates at Organ Pipe Cactus National Monument (NM) in Arizona. We used data from previous research to compile complete species lists for the monument and to assess inventory completeness.

There have been 1,031 species of plants and vertebrates observed at the monument (Table 1). Most of the species on the list are documented by voucher specimens. There are 59 non-native species established in the monument: one mammal, three birds, and 55 non-native plants. Most non-native plant species were first recorded along roads.

In each taxon-specific chapter, we highlight areas that contribute disproportionately to species richness or that have unique species for the monument. Of particular importance are Quitobaquito Springs and Pond, which are responsible for the monument having one of the highest number of bird species in the Sonoran Desert Network of parks. Quitobaquito also contains the only fish in the monument, the endangered Quitobaquito pupfish (Cyprinodon eremus). Other important resources for the plants and vertebrates include the xeroriparian washes (e.g., Alamo Canyon) and the Ajo Mountains. Based on the review of past studies, we believe the inventories of vascular plants and vertebrates are nearly complete and that the monument has one of the most complete inventories of any unit in the Sonoran Desert Network.

Table 1. Summary results of vascular plant and vertebrate inventories at Organ Pipe Cactus NM.

\begin{tabular}{lcc}
\hline Taxonomic group & $\begin{array}{c}\text { Number of } \\
\text { species recorded }\end{array}$ & $\begin{array}{c}\text { Number of } \\
\text { non-native species }\end{array}$ \\
\hline Plants & 642 & 55 \\
\hline Amphibians and Reptiles & 49 & 0 \\
\hline Birds & 285 & 3 \\
\hline Fish & 1 & 0 \\
\hline Mammals & 54 & 1 \\
\hline Total & 1,031 & 59 \\
\hline
\end{tabular}




\section{Chapter 1: Introduction and Overview of Ecological Research and Monitoring at Organ Pipe Cactus National Monument}

\section{Project Overview}

This report is the most recent attempt to summarize research at Organ Pipe Cactus NM with the goal of producing an up-to-date species list for plants and vertebrates. In contrast to our work in other parks in the Sonoran Desert Network (e.g., Powell et al. 2005a), we relied solely on the field work done by others to produce the species lists for Organ Pipe Cactus NM. Species inventories have both direct and indirect value for management of the monument. Species lists are not only useful in resource interpretation and facilitating visitor appreciation of natural resources, but are also critical for making management decisions. Knowledge of which species are present, particularly sensitive species, and where they occur provides for informed planning and decision-making.

\section{Report Format and Data Organization}

This report is intended to be useful for internal planning and outreach, as well as education. We report only common names unless we reference a species that is not listed later in an appendix; in this case we present both common and scientific names. For each taxonomic group we include an appendix of all species that we recorded in the monument (Appendices A-D), and species that were likely present historically or that we suspect are currently present and may be recorded with additional survey effort (except for plants and birds; Appendix E). Species lists are in phylogenetic sequence and include taxonomic order, family, genus, species, subspecies or variety (if applicable) and common name. Scientific and common names used throughout this document are current according to accepted authorities for each taxonomic group: Stebbins (2003) for amphibians and reptiles; American Ornithologist Union (AOU 1998, 2003) for birds; and Baker et al. (2003) for mammals. See Chapter 3 for list of sources used to create the plant list. Units of measurement are presented in accordance with the International System of Units.

\section{Species Conservation Designations}

We indicate species conservation designations by the following agencies: U.S. Fish and Wildlife Service (responsible for administering the Endangered Species Act), Bureau of Land Management, U.S. Forest Service (Region 3), Arizona Game and Fish Department, and Partners in Flight (a partnership of dozens of federal, state and local governments, non-governmental organizations, and private industry).

\section{Voucher specimens}

Voucher specimens are the most indisputable form of evidence of species occurrence. We searched for existing vouchers from Organ Pipe Cactus NM in records from 34 natural history museums (Table 1.1; see Appendix F for results).

\section{Ecological Research and Monitoring at the Monument}

Few natural areas in southern Arizona have received as much ecological research as Organ Pipe Cactus NM. Bennett et al. (1990; and contributors therein) provide an excellent review of research related to cultural and natural resources of the monument and surrounding areas prior to 1981, including abstracts from approximately 250 articles, reports, and notes (the vast majority related to natural resources). We make no attempt to summarize Bennett et al. (1990) and refer the reader there for more information. Yet, much has happened in the intervening years, most importantly with the formation of the Ecological Monitoring Program (EMP).

At the beginning of each taxon-specific chapter, we give a brief introduction to the relevant research and species lists. In this section, we give an overview of fish and invertebrate research and review the ongoing EMP program.

\section{Quitobaquito Pupfish}

The Quitobaquito pupfish (Cyprinodon eremus) is the only species of fish at the monument and it occurs at only a single site there (Quitobaquito Springs and Pond) in addition to only a few sites 
Table 1.1. Museums that were queried (in 1998) for vertebrate voucher specimens with "Arizona" and "Organ Pipe Cactus National Monument" in the collection location. Collections in bold-faced type had specimens from Organ Pipe Cactus NM.

\begin{tabular}{ll}
\hline Brigham Young University & North Carolina State Museum of Natural Sciences \\
\hline California Academy of Science & Oklahoma Museum of Natural History, Norman \\
\hline Chicago Academy of Sciences & Peabody Museum, Yale University \\
\hline Cincinnati Museum of Natural History \& Science & Saguaro National Park \\
\hline Cornell Vertebrate Collections, Cornell University & Strecker Museum, Baylor University, Waco \\
\hline Fort Worth Museum of Science and History & Texas Cooperative Wildlife Collection \\
\hline George Mason University (Fairfax, VA) & Tulane Museum of Natural History \\
\hline Illinois Natural History Survey & U.S. National Museum \\
\hline Marjorie Barrick Museum, University of Nevada-Las Vegas & University of Arizona \\
\hline Michigan State University Museum (East Lansing) & University of Texas, Arlington \\
\hline Milwaukee Public Museum & University of Texas, El Paso \\
\hline Museum of Comparative Zoology, Harvard University & University of Illinois, Champaign-Urbana \\
\hline Museum of Texas Tech University & University of Colorado Museum \\
\hline Museum of Vertebrate Zoology, University of California, Berkeley & University of Michigan \\
\hline Museum of Life Sciences, Louisiana State University, Shreveport & Walnut Canyon National Monument, Arizona \\
\hline $\begin{array}{l}\text { Museum of Natural History, University of Kansas } \\
\text { Natural History Museum of Los Angeles County }\end{array}$ & Western Archaeological and Conservation Center, Tucson \\
\hline
\end{tabular}

outside of the monument (see Hendrickson and Romero 1989). Listed as endangered in 1986 under the Endangered Species Act, the Quitobaquito pupfish is one of several species of pupfish that were once found throughout the Gila River drainage, lower Colorado River and Delta, and the Imperial Valley in California (Miller 1990). Most of these populations are now extinct, presumably because of habitat destruction (Pearson and Connor 2000).

Monument personnel monitor population size at Quitobaquito Springs and Pond annually as part of the EMP (NPS 1998a, 1998b, Tibbitts 1999a, Pearson and Connor 2000). The pupfish appears to be doing well at Quitobaquito; in the last 25 years the population has never dipped below 1,800 individuals (Pearson and Connor 2000); it is currently thought to consist of approximately 8,000 to 10,000 individuals (Douglas et al. 2001). Sampling methods used to estimate population sizes are becoming more accurate (Douglas et al. 2001). A concern to the long-term persistence of the Quitobaquito pupfish is the potential introduction of non-native fish and other vertebrates, invertebrates, and plants (Pearson and Connor 2000).

\section{Invertebrates}

Similar to plants and vertebrates, invertebrates at the monument have been studied, though an inventory for this group is not complete. Bennett et al. (1990) cites 24 studies or notes about invertebrates from the monument. Many of these (and later) studies have focused on the aquatic invertebrates of Quitobaquito (e.g., Kingsley et al. 1987, Larsen and Olson 1997). Kingsley (1998) provided additional summaries of invertebrate collections and studies and he attempted a monument-wide inventory from 1987 to 1990 and found 1,024 species. Kingsley (1995) recommended not using invertebrates in the EMP program due to the rarity of a majority of the species found.

\section{Ecological Monitoring at the Monument}

The designation of the monument as a United Nations Biosphere Reserve in 1976 provided important early initiative to scientists interested in studying the Sonoran Desert. Biosphere reserves are designated because they are thought to represent the most outstanding examples of select ecosystems. It was thought that Organ Pipe Cactus National Monument's isolation and geographic location near the center of the Sonoran Desert provided an 
excellent "laboratory" for research and education. One of the first initiatives after the monument's designation as a Biosphere Reserve was the compilation of all known information on the natural and cultural history of the monument. As noted earlier, the report by Bennett et al. (1990) is an invaluable reference for this information prior to 1981 .

In 1986, monument staff gathered regional experts to help create the first inventory and monitoring program in the region. Modeled after the Channel Islands' Inventory \& Monitoring Initiative, the monument's Sensitive Ecosystems Program (SEP) was designed to determine: (1) the condition of the monument's ecosystems, (2) alternatives available for ecosystem management, and (3) the effectiveness of implemented action programs. Originally titled the "Sensitive Habitats Projects" (in 1984), the SEP program included a broad range of natural resource studies at the monument, specifically baseline inventories to include plants, songbirds, and nocturnal rodents (Bennett and Kunzman 1987). The program was expanded in 1991 to implement some of the recommended long-term monitoring protocols
(Table 1.2). Finally, in 1994, the title of the program changed to the Ecological Monitoring Program (EMP) to "reflect a change from the historic focus on 'sensitive' monument areas to a broader look at the ecosystem's many components" (NBS 1995). Prior to the initiation of the NPS Inventory and Monitoring Program (NPS 1992; of which the Sonoran Desert Network is one program), the Organ Pipe Cactus NM EMP was one of the most extensive ecological research and inventory and monitoring programs in the National Park Service. Because of early interest in the monument by ecologists, the monument had fairly complete species lists of plants and vertebrates, well ahead of other park units in southern Arizona.

According to Rowlands (1999), data from the EMP has guided management of natural resources at the monument by providing basic biological inventories and distribution data for species of concern (e.g., buffelgrass and the cactus ferruginous pygmy-owl). He suggested that the data provide a comprehensive summary of the monument's importance in maintaining biodiversity and ecological function in the Sonoran Desert.

Further, the program has been recognized as an

Table 1.2. Components of the Organ Pipe Cactus National Monument Ecological Monitoring Program (EMP). Although a component of the EMP, natural history studies are observational and are used to describe ecosystem components and are useful for interpretation. Table from Hubbard et al. (2003).

\begin{tabular}{|c|c|c|c|c|}
\hline \multirow[b]{2}{*}{ Category } & \multirow[b]{2}{*}{ Component } & \multicolumn{3}{|c|}{ Type of study } \\
\hline & & Monitoring & Inventory & Natural history \\
\hline \multirow[t]{5}{*}{ Physical environment } & Atmospheric deposition & $\mathrm{X}$ & & \\
\hline & Water quality & $X$ & & \\
\hline & Air quality-visibility & $X$ & & \\
\hline & Climate (precipitation, humidity, temperature) & $\mathrm{X}$ & & \\
\hline & Well depths & $X$ & & \\
\hline \multirow[t]{6}{*}{ Vertebrates } & Nectar-feeding (Leptonycteris) bats & $X$ & & \\
\hline & All other bats & & $X$ & $X$ \\
\hline & Birds & $X$ & $X$ & $X$ \\
\hline & Lizards & $\mathrm{X}$ & & $x$ \\
\hline & Quitobaquito desert pupfish & $X$ & & $X$ \\
\hline & Nocturnal rodents & $X$ & & $X$ \\
\hline \multirow[t]{7}{*}{ Vascular plants } & Acuña cactus & & $X$ & $x$ \\
\hline & Organ pipe cactus growth rates & & $x$ & $x$ \\
\hline & Senita cactus growth rates & & $X$ & $X$ \\
\hline & Gearstem cactus flowering phenology & & $x$ & $x$ \\
\hline & Desert caper & & $\mathrm{X}$ & $X$ \\
\hline & Grazing recovery & & $X$ & $\mathrm{X}$ \\
\hline & Vegetation structure and diversity & & $X$ & $X$ \\
\hline Human impacts & Surrounding land use trends & & $X$ & \\
\hline
\end{tabular}


important early effort in comprehensive ecological monitoring in the Sonoran Desert and as a valuable "prototype" program from which others may learn. Unfortunately, the program has experienced many of the pitfalls that are common among ecological monitoring programs (Noon 2003). Hubbard et al. (2003) identified those problems as: (1) lack of clear parameter identification and objectives, (2) unclear reason for choosing indicators, (3) problems with the spatial sampling design, and (4) lack of comprehensive data analyses. We believe that the program needs a thorough review (based on comprehensive data analysis), which is essential for the long-term efficacy of the program (e.g., McEachern 2000).

Despite some of the program's challenges, it remains the longest-running ecological monitoring program in the region for most of the parameters being measured. Therefore, it has value for detecting trends in these parameters, and for informing other monitoring programs in the region. In particular, it will be valuable for informing monitoring decisions for the Sonoran Desert Network Inventory and Monitoring Program. In addition, park personnel are resuming annual reporting of their findings which was suspended in 1996 (Peter Holm, pers. comm.).

\section{Endangered Species Monitoring}

The monument has an active monitoring program for four endangered species. The Quitobaquito pupfish is restricted to Quitobaquito Springs and pond. The southern (lesser) long-nosed bat forages throughout the monument where saguaro and organ pipe cactus are present, and the largest known maternity roost in the U.S. is within the monument. The cactus ferruginous pygmy-owl occurs in relatively dense and diverse Sonoran Desertscrub associations, chiefly in the eastern and northern portions of the monument. The Sonoran pronghorn occurs primarily west of Highway 85. The monument carries out monitoring and management of these species in cooperation with the U.S. Fish and Wildlife Service, Arizona Game and Fish Department, and others. 


\section{Chapter 2: Monument Overview}

\section{Monument Area and History}

Organ Pipe Cactus National Monument (NM) is located near the heart of the Sonoran Desert in southwestern Arizona, adjacent to Mexico (Fig. 2.1). At $133,830 \mathrm{ha}$, it is the largest park unit in the Sonoran Desert Network (Fig. 2.2). The monument was established in 1937 to preserve the largest portion of desert in the United States with the park's namesake, the organ pipe cactus. The monument was designated as a United States Biosphere Reserve in 1976 by the United Nations Educational, Scientific and Cultural Organization (UNESCO). This designation signifies that the monument contains an outstanding, internationally significant ecosystem. The UNESCO designation prompted the NPS to interpret the management objectives for the monument as preserving the monument as a "representative example of the natural and cultural resources of the Sonoran Desert" and "to serve as a natural laboratory for understanding and managing Sonoran Desert ecosystems" (NPS 1994a). Current annual visitation to the monument is approximately 270,000 (NPS 2005).
Although large in size, the monument is dwarfed by the major land management units surrounding it: Cabeza Prieta National Wildlife Refuge to the west and north, the Tohono O'odham Indian Reservation to the east, and Bureau of Land Management land to the north (Fig. 2.3). In Mexico, El Pinacate y Gran Desierto de Altar (also a designated UNESCO Biosphere Reserve) borders the monument.

Archaeological evidence suggests that humans occupied the monument as far back as 12,000 years ago (Rankin 1991). Quitobaquito Springs has been an active site for settlement in recent history, and it was an important source of water for Spanish explorers and migrants attempting to cross the Sonoran Desert (Bennett and Kunzman 1989). Today, there are a number of sites at the monument that are sacred to the Tohono O'odham. Livestock grazing was the livelihood for a number of families who lived in the area, but was discontinued in 1976 (NPS 1997). Prior to the creation of the monument there were numerous active mining claims.

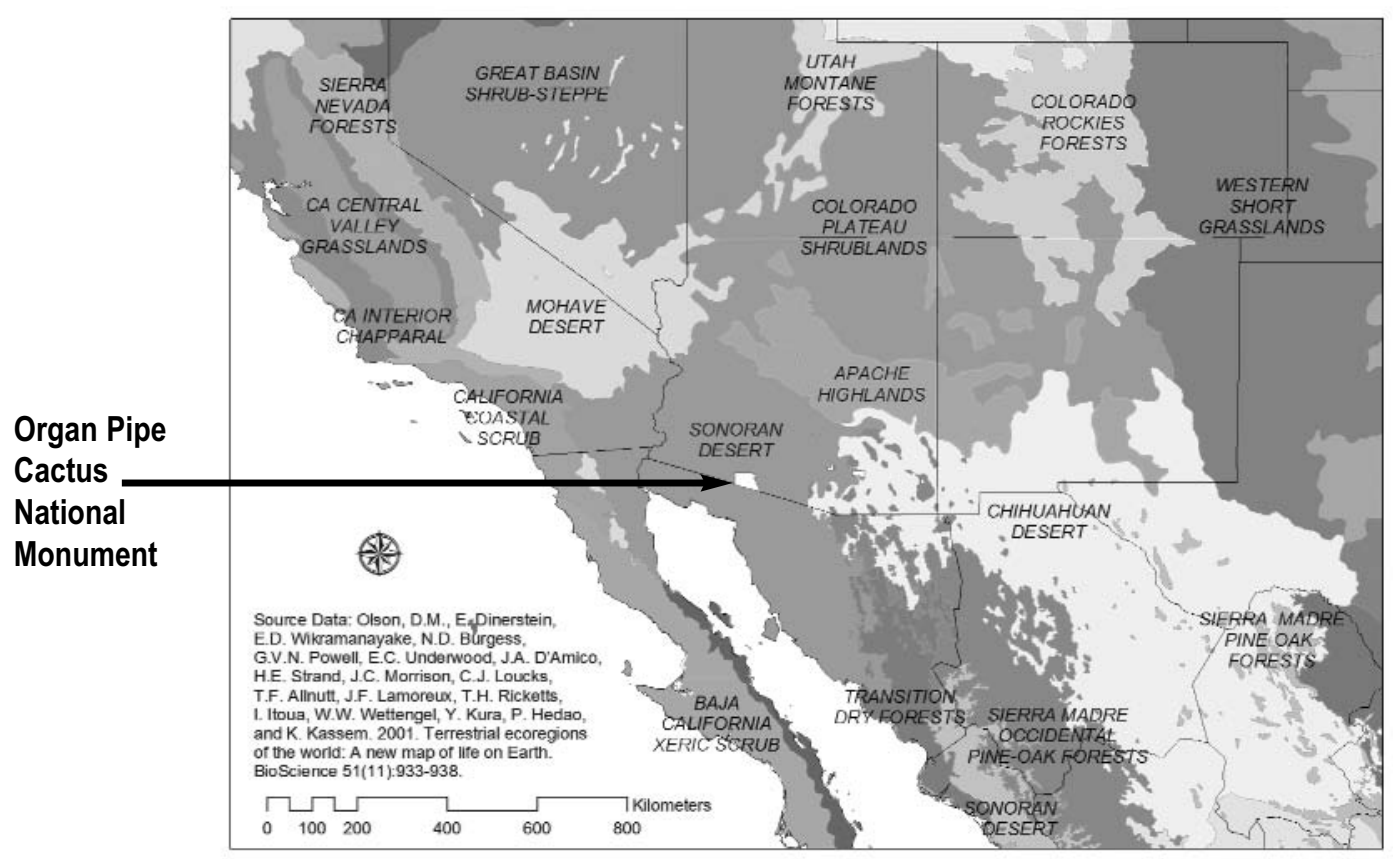

Figure 2.1. Diagram of major ecological provinces of the southwestern United States and northwestern Mexico. 


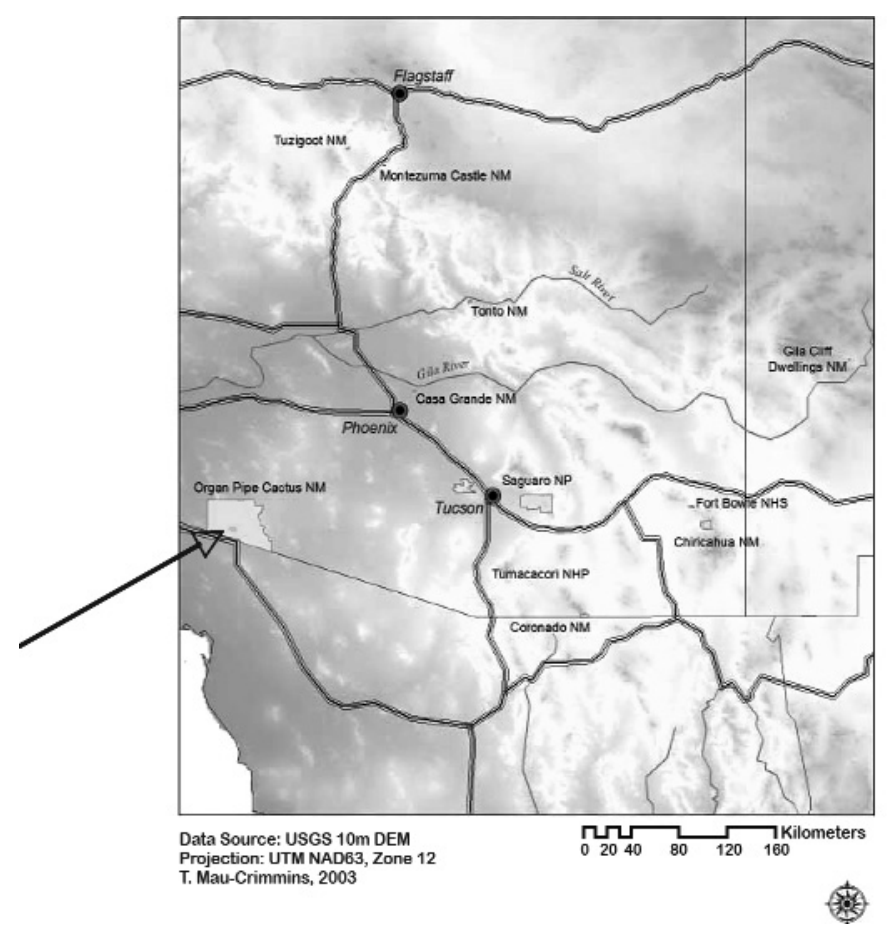

Figure 2.2. Location of Organ Pipe Cactus NM in relation to other parks in the Sonoran Desert Network of parks.

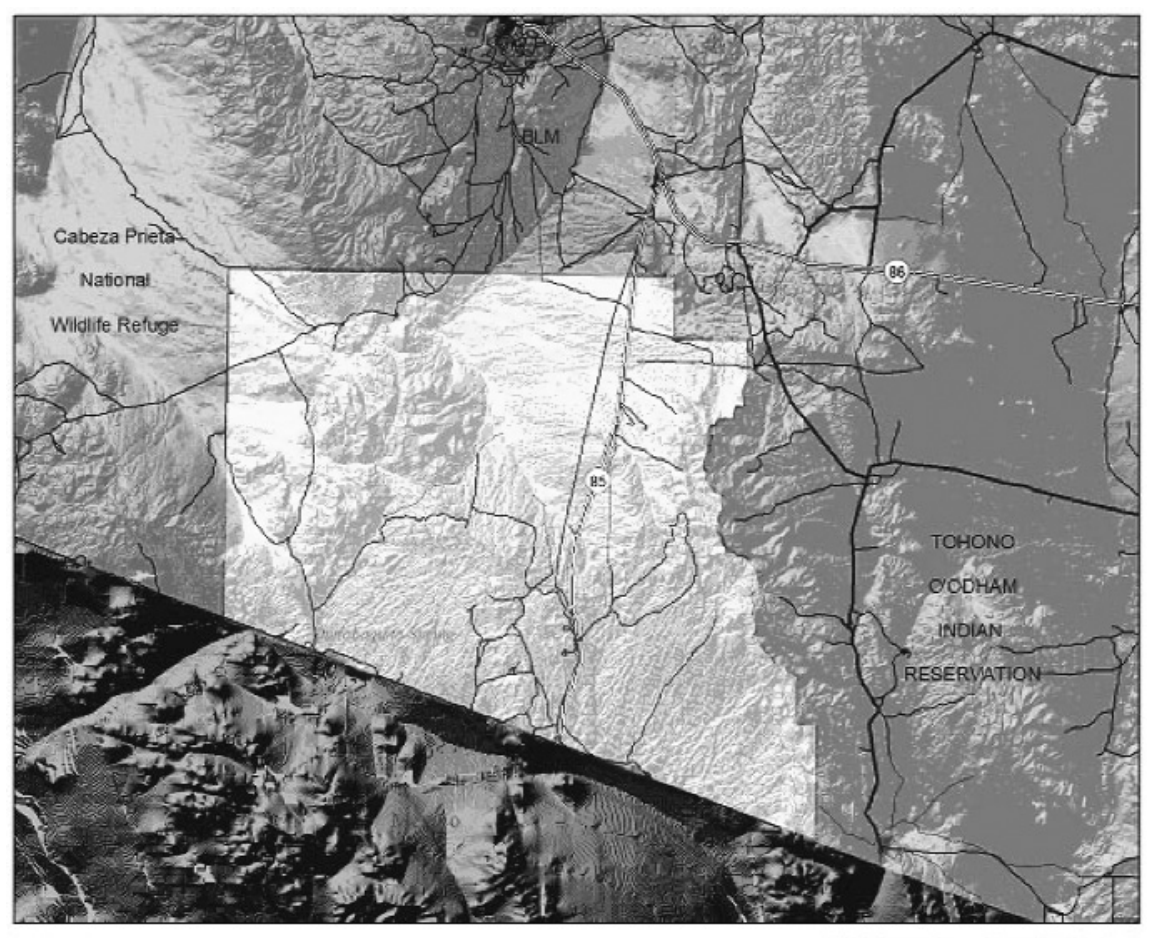

Data Source: GAP Stewardship, USGS $10 \mathrm{~m}$ DEM Propection: UTM NAD83, Zone 12
T. Mau-Crimmins. 2003

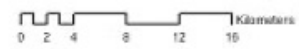

Figure 2.3. Map of Organ Pipe Cactus NM showing topography and neighboring land ownership. 
Table 2.1. Average monthly climate data for Organ Pipe Cactus National Monument, 1948-2004. (Data from WRCC 2005).

\begin{tabular}{|c|c|c|c|c|c|c|c|c|c|c|c|c|c|}
\hline \multirow[b]{2}{*}{ Characteristic } & \multicolumn{12}{|c|}{ Month } & \multirow[b]{2}{*}{ Annua } \\
\hline & Jan & Feb & Mar & Apr & May & Jun & Jul & Aug & Sep & Oct & Nov & Dec & \\
\hline Maximum temperature $\left({ }^{\circ} \mathrm{C}\right)$ & 20.2 & 22.3 & 24.9 & 29.1 & 33.3 & 38.1 & 39.6 & 38.8 & 36.9 & 31.6 & 24.8 & 20.4 & 30.0 \\
\hline Minimum temperature $\left({ }^{\circ} \mathrm{C}\right)$ & 3.8 & 5.1 & 6.8 & 9.7 & 13.6 & 18.2 & 23.2 & 22.6 & 19.5 & 13.4 & 7.2 & 3.9 & 12.2 \\
\hline Precipitation $(\mathrm{cm})$ & 2.1 & 1.8 & 2.1 & 0.7 & 0.3 & 0.3 & 3.5 & 4.9 & 2.4 & 1.9 & 1.5 & 2.9 & 2.0 \\
\hline
\end{tabular}

\section{Natural Resources Overview}

\section{Physiography, Geology and Soils}

Organ Pipe Cactus NM is located in the Basin and Range Geologic Province and its topography varies from deep alluvial valleys to steep, rugged mountain ranges. Elevation at the monument is as low as $305 \mathrm{~m}$ and extends to $1,465 \mathrm{~m}$ at the eastern boundary of the monument in the Ajo Mountains, the monument's most prominent geologic feature. Geology of the mountains is the result of volcanic flows during the Cretaceous, Tertiary, and PlioPleistocene periods. The valleys of the monument are formed of alluvial material originating in the mountains and transported down via streams and sheet-flows (Warren et al. 1981). Soils at the monument are all considered aridosols (for a complete soil survey, see Chamberlin 1972).

\section{Hydrology}

There are no perennial rivers or streams within the monument, though there are 11 springs, four with perennial flow. The most prominent spring, Quitobaquito, feeds a large human-made pond, the second largest natural oasis in the Sonoran Desert. Quitobaquito Spring has been the subject of considerable cultural and natural resource research, the latter being reviewed in Chapter 1 . Two of the other perennial springs and five of the intermittent springs occur near the Quitobaquito area. The other perennially flowing spring (Dripping Spring) is located in the Puerto Blanco Mountains. There are 60 tinajas (natural depressions in bedrock that hold water) throughout the monument and they are the most widespread source of seasonal water.

\section{Climate}

Organ Pipe Cactus NM experiences an annual bimodal pattern of precipitation which is characterized by heavy summer (monsoon) storms brought about by moisture coming from the Gulfs of Mexico and California, and less intense frontal systems coming from the Pacific Ocean in the winter. On average, approximately one-half of the annual precipitation falls from July through September (Table 2.1; WRCC 2005). The area's hot season occurs from May through September; maximum temperatures in July can exceed $40^{\circ} \mathrm{C}$. Winter temperatures rarely dip below freezing. The average annual precipitation total for the monument is $24.3 \mathrm{~cm}$ (Table 2.1).

\section{Vegetation}

According to Warren et al. (1981), the monument has six plant communities (i.e., biomes):

- Great Basin conifer woodland containing oneseed juniper-Arizona rosewood mixed shrub association;

- Madrean evergreen forest and woodland containing Ajo Mountain scrub oak-mixed shrub association;

- Sonoran riparian woodland containing honey mesquite riparian woodland association;

- Interior chaparral containing rock gooseberry-common hoptree mixed scrub association;

- Sonoran desertscrub containing 23 associations dominated by creosote bush, burrobush, ragweed, ocotillo, palo verde, jojoba, ironwood, acacia, organ pipe cactus, and salt bush;

- Sonoran interior marshland containing southern cattail-chairmaker's bulrush association and inland saltgrass-rush association.

\section{Natural Resource Management Issues}

\section{Border Crossings}

Ten years ago, the trespass of drug smugglers and undocumented immigrants (border crossers) across the U.S./Mexico border was not considered an important natural resource management issue (NPS 1994a). Today, this issue is one of the greater 
challenges to the ecological integrity of the monument. It is estimated that 500 border crossers enter the U.S. through the monument each day and approximately 700,000 pounds of drugs are brought through the monument each year (NPS 2003a). Border crossers can pose a serious threat to visitors, employees, and personal property at the monument. They also create a network of trails, leave trash, and destroy soils and vegetation. Finally, there is concern that excessive use of the major springs and water sources has led to water contamination (Sprouse et al. 2002). Park personnel are currently mapping trails and monitoring trash deposition by undocumented immigrants (NPS 2003a).

The movement of illegal vehicles crossing into the monument and subsequent border patrol vehicle pursuits has caused severe damage to fragile desert resources. Responding to this threat, the NPS constructed a vehicle barrier across most of the monument's border with Mexico (NPS 2003b). The barrier will likely prevent some animal movement, but the anticipated drop in offroad vehicle traffic and associated impacts are thought to generally improve soil stability and habitat for plants and animals (NPS 2003b).

\section{Adjacent Land Use}

There is intensive agricultural development and urbanization associated with the neighboring town of Sonoyta, Mexico (Brown 1991). Sonoyta's population is currently about 20,000 and is expected to increase. In the late 1980 s, groundwater for irrigating crops in the Sonoyta Valley was being pumped out of the aquifer at 2.5 times the rate of recharge (Barnett and Sharrow 1992). The aquifer used for irrigation near Sonoyta appears to be shared by the southern portion of the monument (but not Quitobaquito Springs; Carruth 1996), and the subsequent lowering of the water table poses a potential threat to the monument's natural resources. In recent years, this issue may have been less severe because of a reduction of agriculture in the area (Ami Pate, pers. comm. to Andy Hubbard). There is also concern about the overexploitation of ironwood trees (for cooking fuel, charcoal, and wood carving) along the Mexican boundary and how this collecting impacts the populations within the monument (Suzan et al. 1997, 1999).

\section{Vertebrate Mortality along Arizona Highway Route 85}

Arizona Highway Route 85 runs north/south and dissects the monument (Fig. 2.3). Roads are a common source of vertebrate mortality (Rosen and Lowe 1994); they act as barriers to the dispersal of small mammals, thereby creating subpopulations (Oxley et al. 1974, Adams and Geis 1983); deter, disturb and alter movement patterns of songbirds and medium and large mammals (Forman and Alexander 1998, Trombulak and Frissell 2000); and pollute soil and water via runoff. Roads may also attract many vertebrates, ultimately leading to them being killed by vehicles. Herbaceous plant species thriving along roadsides from runoff attract granivorus birds and small mammals (Oxley et al 1974, Adams and Geis 1983, Forman and Alexander 1998, Trombulak and Frissell 2000) and road surfaces provide warmth to ectothermic reptiles and amphibians (Rosen and Lowe 1994, Rosen and Lowe 1996).

\section{Animal Poaching and Collection}

Organ Pipe Cactus NM has several species of plants and vertebrates that are of interest to illegal collectors and poachers. Many plants, such as some cacti, are of value for landscaping purposes and many woody plant species are scavenged by border crossers for fire and shelter (NPS 2003a).

According to a study by Rosen and Lowe (1996) many species of reptiles, such as the rosy boa, Gila monster, chuckwalla, sidewinder, tiger rattlesnake, and desert tortoise found in the monument are collected for personal collections or for the pet trade. Rosen and Lowe (1996) found signs of illegal collecting at Alamo Canyon and Eagle Pass in the monument.

\section{Aircraft Noise}

Low-flying military aircraft from Luke and Davis Monthan Air Force Bases, law enforcement aircraft from the U.S. Border Patrol, and private aircraft often pass over the monument (NPS 1994b). Both vibrations and noise generated by these aircraft affect the natural quiet of the monument and may also affect wildlife in the area (NPS 1994b). Aircraft overflights can produce changes in the physiology and behavior of some wildlife species (Luz and Smith 1976, Weisenberger et al. 1996). 


\section{Chapter 3: Plants}

The monument's flora is the most complete of any large natural area in the desert southwest and is the result of many studies. The first known species list for the monument was created by McDougall (1945) and was based on his collections and those by A. A. Nichols from 1939 (Rutman 2005). Their list included approximately 300 species. Other early collections were made by Ora Clark, a science teacher in Ajo during the late 1930s and early 1940s. Specimens from these collections still remain at the monument and/or at the University of Arizona Herbarium. There were three subsequent, unpublished floras for the monument (reviewed in Pinkava et al. 1992) but Bowers (1980) produced the first annotated flora. She reported 518 species. Other additions to the flora included: Pinkava et al. (1992; 52 new species) and Felger et al. (1992; species list and ethnobotany at the Quitobaquito area). Principle works on the non-native plants of the monument include Felger (1990) who reviewed plant specimens from four herbaria and his own field observations and Halvorson and Guertin (2003) who provided location information for 17 species of non-native plants. Ruffner and Associates (1995) identified 44 species of plants that were in need of monitoring because of "sensitivity to disturbance" or because they were deemed to be indicators of change.

There have been a number of vegetation studies in the monument. Steenberg and Warren (1977) constructed exclosures at four sites to determine the impacts of grazing on plant community structure and composition. These exclosures were resurveyed by Warren and Anderson (1995). Warren et al. (1981) classified and mapped dominant (perennial) vegetation at the monument. Bowers (1990) reviewed past studies from the region, provided a historical context for vegetation changes, and used repeat photography to illustrate some important changes. Brown and Warren (1986) plotted the location and calculated density of riparian vegetation in and around Quitobaquito Springs and Pond. Parker (1991) established vegetation and environmental relationships at 100 sites throughout the monument. Lowe et al. (1995) designed the vegetation monitoring protocol for the EMP.
Finally, Sue Rutman and Richard Felger are writing a book-length annotated flora for the monument (Sue Rutman, pers. comm.)

\section{Data Used To Create Plant Species List}

The flora for the monument (Appendix A) is based entirely on the list by Rutman (2005). That list is specimen-based and was assembled by compiling a list of specimens in herbaria at the monument, Arizona State University (ASU), and the University of Arizona (UA). All specimens were reviewed by experts, most notably Richard Felger and Sue Rutman. Alva Day verified the gilia (Gilia sp.) specimens, Andrew Salywon reviewed difficult species in the Brassicaceae family, and John and Charlotte Reeder verified many of the grass specimens in the monument's herbarium (Sue Rutman, pers. comm.). Some specimens were reviewed by Thomas H. Kearney. Excluded from the monument's flora are species that were waifs (their appearance was rare and transitory) and for which no reproducing populations were established.

Unlike the other species lists in this report and other flora created by our program (e.g., Powell et al. 2005b), we do not attempt to compile historical data from sources other than the Rutman (2005) species list. Rutman (2005) primarily used Flora of North America (FNA 1993) as a taxonomic references for her list, but also used W3Tropicos (a web-based resource, MGB no date), USDA (a web-based resource, USDA no date) and other resources.

\section{Results and Discussion}

There have been 642 species of plants found at the monument (Appendix A), of which 55 (9\%) are non-native. This plant list was the result of dozens of collectors over approximately 75 years and represents one of the most complete floras of the region.

Compared to others in Arizona, the monument's flora is not particularly species rich (Bowers 1980). For example, Powell et al. (2005b; and citations therein) found almost the same number of species (638) at Fort Bowie National 
Historic Site in southeastern Arizona, an area $<0.5 \%$ the size of Organ Pipe Cactus NM. Bowers (1980) provides similar comparisons to other floras in southern Arizona. However, within the monument there are areas of high species richness, most notably Quitobaquito Springs and Pond and the Ajo Mountains. Bowers (1980) found 163 species occur in the Ajo Mountains, which comprise about $10 \%$ of the area of the monument. This high species richness is primarily due to topographic relief, soil-texture gradients, and temperature and rainfall (Bowers 1980, Parker 1991). In addition, a number of species reach the western-most limit of their geographic ranges in the Ajo Mountains, including some with distinctly Madrean affinities (Bowers 1980).

The number of non-native plant species recorded in the monument $(n=55,9 \%$ of all species) is low, although slightly higher than Saguaro National Park, Rincon Mountain District (approx. 7\%, Powell et al. 2006), which has the lowest percentage of non-native species in the Sonoran Desert Network. Non-native plants are an important management concern because they alter ecosystem function and processes (Naeem et al.
1996, D'Antonio and Vitousek 1992), reduce abundance of native species, and cause potentially permanent changes in diversity and species composition (Bock et al. 1986, D'Antonio and Vitousek 1992, OTA 1993). However, some species have stronger impacts on the ecological community than others. In assessing the potential threat posed by non-native species, it is important to consider the spatial extent of species, particularly those species that have been identified as "invasive" or of management concern. Felger (1990) found 14 species, including red brome and buffelgrass, to be "thoroughly" invasive and an additional 10 species - including smooth barley, crimson fountaingrass, Sahara mustard, and common sowthistle - that have become established on disturbed sites.

\section{Inventory Completeness}

The plant inventory for Organ Pipe Cactus NM is considered complete. However, the monument is large and there are undoubtedly established species that have not been found and new species (especially non-native), that will become established. 


\section{Chapter 4: Amphibians and Reptiles}

There have been a number of studies of amphibians and reptiles at Organ Pipe Cactus NM. Lowe (1990) provided an excellent summary of early herpetofauna studies and collections by Gloyd (1937), Huey (1942), Hensley (1950), and Lowe and Supernaugh (1953). Lowe (1990) also provided a species list based on these and other collections. Gloyd (1937) noted the distribution of reptiles and amphibians in southern Arizona, including parts of the monument. Huey (1942) conducted an inventory of the entire monument, and Hensley (1950) collected specimens incidentally and while driving the monument's roads. Lunsford and Lapidus (1977) created an annotated species list for the monument but John Cross (1977; assistant curator of herpetology collection at the UA) and others (Lowe 1990) have questioned the accuracy of that list. More recently, Rosen and Lowe (1996) conducted an inventory and established a long-term monitoring program. Rosen and Lowe (1995) wrote the monitoring protocol for lizards (summarized in NPS 1998a, 1998b, Connor and Rosen 1996). Rosen and Lowe (1994, 1996) conducted a study on highway mortality of snakes. Lowe and Rosen (1991) and later Rosen and Lowe (1996) created the most upto-date species list, the latter being the most definitive annotated species list for the monument. Rosen (2000) used data from the EMP and his own data to investigate community patterns for lizards and snakes. From 1995 to 1997, Wirt et al. (1999) conducted a monument-wide survey of desert tortoise. In 2005 Phil Rosen (unpubl. data) studied desert tortoise near Highway 85 and Matt Goode (unpubl. data) studied tiger rattlesnakes in the Ajo Mountains.

\section{Data Used to Create Herpetofaunal List}

We base our amphibian and reptile species list (Appendix B) entirely on the thorough list created by Rosen and Lowe (1996) and museum specimens listed in Appendix F. The list by Rosen and Lowe (1996) was created using many of the previously mentioned lists, studies, and collections, in addition to over 600 field days of their own research. Most of the species on the list are backed by voucher specimens located at the monument and the UA Amphibian and Reptile Collection (Appendix F).

\section{Results and Discussion}

There are 49 species of amphibians and reptiles that are known to occur at the monument: five toads, two turtles, 16 lizards, and 26 snakes (Appendix B). There were no non-native species found to breed at the monument.

The high diversity of herpetofauna at the monument is related to its size and variety of biotic communities. Reptiles are well represented at the monument, particularly lizards and snakes. Rosen and Lowe (1996) assert that dominant physical features of the monument's geology and soils separate the lizards and snakes into three communities: (1) rock piles, (2) bajadas, and (3) valley-bottom fills. Two "true" desert species inhabit only rock piles: common chuckwalla and speckled rattlesnake. By contrast, six species (including: desert horned lizard, western shovelnosed snake, and sidewinder) inhabit the valleybottom fills (containing fine-textured soils) where the vegetation community is lower Colorado Valley Sonoran Desertscrub. Finally, the bajadas contain some species associated with Arizona Upland Sonoran Desertscrub: tree lizard, regal horned lizard, and Sonoran shovel-nosed snake (Rosen and Lowe 1996). Another important community within the monument is xeroriparian desertscrub along washes, which hosts a number of species such as the western coralsnake and common kingsnake. Rosen and Lowe (1996) noted that washes became particularly important during droughts when species from adjacent areas use the washes more than in times of normal rainfall.

Rosen and Lowe (1995) established lizard transects at 13 sites throughout the monument as part of the EMP. They used distance sampling, a detectability-adjusted method that allows for unbiased estimates of density. Data from this project have been summarized (Connor and Rosen 1996, Rosen 2000) but a more thorough analysis of the data holds great promise to determine population-level changes in the monument. 
Rosen and Lowe (1996) created a list of species that they considered threatened because of (1) range-wide or local population decline, (2) potential for poaching, and/or (3) susceptibility to mortality on Arizona Highway Route 85. The list included the desert tortoise (a federal Species of Concern and an Arizona state Wildlife Species of Concern) and tiger rattlesnake, species that are targeted by collectors. Both the rosy boa (a federal Species of Concern and a Sensitive Species according to BLM) and the Sonoran shovel-nosed snake (a Sensitive Species according to the USFS) are also targeted by collectors and are often killed on roadways. The Sonoran mud turtle is probably undergoing a population decline and it is restricted only to Quitobaquito Pond. The canyon spotted whiptail, a federal Species of Concern, has its largest known population in the Ajo Mountains, which are only partially encompassed by the monument. The following species have restricted distributions, isolated populations, population centers off the monument, or are uncommon: Sonoran green toad, longtailed brush lizard, desert horned lizard, black-necked garter snake, southwestern black-headed snake, speckled rattlesnake, Sonoran whipsnake, and western shovel-nosed snake. The one additional species not listed by Rosen and Lowe (1996) that is federally listed as a Species of Concern is the common chuckwalla. Rosen and Lowe (1996) foresaw no immediate threat to this species.

\section{Inventory Completeness}

The species list, created by Rosen and Lowe (1996), covers specimens collected from the monument over the last six decades (Appendix B). Although this is most likely a complete list, Rosen and Lowe (1996) believe several additional species are possible in the monument.

If found in the monument, the northern casque-headed frog would be in dry washes and the Great Plains narrow-mouthed toad would be near springs or ephemeral pools (Stebbins 2003). If present, both species would be on the northernmost extent of their range in Arizona (Stebbins 2003).

Two additional species of lizards may be found in the monument: desert night lizard and Madrean alligator lizard. The desert night lizard occurs only in isolated populations in Arizona and is usually associated with yucca, which occurs in the Ajo Mountains. The Madrean alligator lizard is very unlikely, but if found at the monument, it would also be in the Ajo Mountains.

The monument has likely experienced loss of species in the last few decades. Two native species, the Mexican spadefoot (Spea multiplicata) and yellow mud turtle (Kinosternon flavescens), were previously documented in the monument but are believed to no longer be present (Rosen and Lowe 1996).

Four non-native species: tiger salamander (Ambystoma tigrinum), American bullfrog (Rana catesbeiana), painted turtle (Chrysemys picta), and pond slider (Trachemys scripta) have also been documented at the monument but no longer occur there. 


\section{Chapter 5: Birds}

The bird fauna of the monument has been extensively surveyed over the past century. Mearns (1907) was the first to report on the birds of the monument; he spent a month in 1894 near Sonoyta, Mexico and Quitobaquito Springs. Huey (1942) conducted approximately 90 days of general surveys over the entire monument for all vertebrates, especially mammals and birds. Hensley (1954) recorded bird species and nests around natural permanent water sources and mountain canyons, and conducted line-transect surveys in the intermountain regions of the monument. Hensley (1959) and Phillips and Pulich (1948) studied common nesting birds of the monument. Tallman (1970), an ornithology professor from Northern State College, spent approximately two months netting and observing birds at Quitobaquito and Williams springs. Johnson et al. (1983) studied breeding birds on two plots bordering Quitobaquito Springs. Parker (1986) similarly studied bird community structure, nest-sites, and foraging of common species at one site in the monument, in an area that was dominated by creosote bush and triangle burr ragweed. Halterman et al. (1999) studied the impacts of brown-headed cowbirds on nesting birds at the monument and established eight transects in xeroriparian areas. Volunteers and monument staff conducted Christmas Bird Counts at the monument from 1966 to 1984 (NAS 2005) and two Breeding Bird Survey Routes, which were surveyed irregularly from 1990 to 2003 (Sauer et al. 2005). Benson et al. (2001) reviewed the use of the Mapping Avian Productivity and Survivorship (MAPS) program (mist netting) in Growler Wash and Alamo Canyon in 1997 and 1998. Johnson (1995) designed the bird-monitoring portion of the EMP, but that protocol was abandoned in 1995. In 1997 a new protocol was developed, which was modified a few times up until 1999 (e.g., NPS 1998a, 1998b). The new protocol was used from 1999 to 2004 (Tibbitts 2003). Tibbitts (2003) provides a synthesis of the changes to the bird monitoring protocol since 1995.

Steenbergh and Hoy (1963) created the first species list for the monument; it summarized observations made by researchers and the general public from 1939 to 1963. Subsequent lists included: Cunningham (1969, 1971), Wilt (1976; the first annotated list), and Brown et al. (1985). The most comprehensive annotated list was by Groschupf et al. (1988) and later revised by Tibbitts and Dickson (2005).

\section{Data Used to Create Bird List}

The bird list for the monument is based on Groschupf et al. (1988) and Tibbitts and Dickson (2005). We also include summaries by Benson et al. (2001). Taken together, these lists represent one of the most thoroughly documented bird species lists of any in the region. Like the lists for plants and herpetofauna, the bird list is an outstanding example of one built on past efforts with periodic updates.

\section{Results and Discussion}

There have been 285 species of birds recorded at the monument (Appendix C). Of these, three are non-native species and 73 require open water and/or marshland (found at Quitobaquito Pond): 21 species of ducks and geese (Anatidae), four species of grebe (Podicipedidae), seven species of heron and egret (Ardeidae), five species of rail (Rallidae), 19 species of "shorebirds" (Charadriidae, Recurvirostridae, and Scolopacidae), nine species of gulls (Laridae), and eight other species.

Based on this list, Organ Pipe Cactus NM has the highest bird diversity of any unit in the Sonoran Desert Network. This diversity results from three main factors. First, the monument has had extensive surveys and observations over the past century, which has enabled the monument to have a near complete species list. The second factor is that many species have their northernmost distribution at the monument (i.e. crested caracara). The third factor determining the diversity of birds at the monument is the variety of biotic communities within the monument itself: from mixed Sonoran desertscrub to the juniper-oak woodland/mixed mountain scrub to marsh and open water. The diversity of major vegetation communities and the variety and gradient of topographic features are major determinants of bird 
diversity in the southwest and elsewhere

(Rosenberg et al. 1991).

Quitobaquito provides an oasis of open

water and marsh in an area otherwise devoid of surface water. This important resource attracts birds requiring open water and also hosts many migrants en route to more northern or southern wintering or summering areas. Several species that use this open water and marsh are federally listed as Endangered or Species of Concern including the wood stork, brown pelican and white-faced ibis. Although extremely rare at the monument, they have been found at Quitobaquito Pond.

Another important resource for birds is the xeroriparian areas along washes such as Alamo Canyon and Growler Wash. Hardy et al. (2004) surveyed ecologically similar areas north of the monument and found that most of the spring passage migrant species preferentially selected dry washes, and many species used them exclusively. Also, many of the species that breed at the monument prefer the xeroriparian washes compared to upland sites, presumably because washes provide cooler microsites and protection from predators (Parker 1986).

\section{Inventory Completeness}

The bird list is one of most complete lists of its kind in the region. In the 17 years since the excellent work by Groschupf et al. (1988), only 11 species have been added to the list (Tibbitts and Dickson 2005). This indicates that the bird species list is nearly complete. However, because birds are highly mobile animals, it is difficult to compile a truly complete list of birds, especially for Organ Pipe Cactus NM, which is well known for species that seldom enter the U.S. from Mexico. Also, it is likely that even more birds requiring open water will be found at Quitobaquito Pond because of its proximity to the Gulf of California. 


\section{Chapter 6: Mammals}

Mearns (1907) was the first collector at the monument. He and others collected vertebrates at Quitobaquito and others areas around Sonoyta, Mexico in 1894. Huey (1942) was the first to report on the mammals from throughout the monument. From the 1930s through the 1950s, a number of researchers collected voucher specimens from the monument (NPS 1994a). Subsequent research was focused on single-species habitat assessment and population estimation: desert bighorn sheep (Coss 1964, Carrico 1969, Douglas 1975), feral burro (Hungerford 1976), white-tailed deer (Henry and Sowls 1980), and western whitethroated woodrat (Olsen 1970).

Steenbergh and Warren (1977) quantified vegetation characteristics and trapped small mammals in grazed and ungrazed areas of the monument to establish the effects of livestock grazing. Warren and Anderson (1995) resampled vegetation at these sites, but to our knowledge, the rodent trapping has never been repeated. Other rodent trapping efforts included establishment of trapping grids as part of the EMP program (Petryszyn 1995a; results reported in NPS 1998a, 1998b, and Petterson 1999) and associated programs (Rosen 2000). Petryszyn and Russ (1996) also used data from the EMP program. Trapping currently takes place annually at 16 EMP sites.

Bats are also well surveyed at the monument. Cockrum (1981) trapped bats in 1979 and 1980 and reviewed past information to create a species list of bats for the monument. Petryszyn and Cockrum (1990) trapped at Quitobaquito Pond in 1981 and 1982 and created a species list of other mammals they found there. Petryszyn (1995b) prepared the bat monitoring protocol for the EMP and results were reported in annual reports (NPS 1998a, 1998b and Pate and Petterson 1999). More recently, Petryszyn et al. (1998), Pate et al. (1999), and Tibbitts et al. (2002) have monitored and studied foraging, surface water use and roosting areas of bats at the monument. Tibbitts (1999b) reported on the roost-site investigations of the endangered southern long-nosed bat.

Species lists for the monument were made by Huey (1942) and later by Cockrum (1984 and 1990). The most complete annotated list for the monument was by Cockrum and Petryszyn (1986).

\section{Data Used to Create Mammal List}

The list of the monument's mammals (Appendix D) is based on Cockrum and Petryszyn (1986), with additions based on results from the EMP studies and species collected: NPS (1998a, 1998b) and sections in Pate (1999).

\section{Results and Discussion}

The current list of mammals for Organ Pipe Cactus NM consists of 54 species: 14 bats, 20 small, terrestrial mammals (principally rodents) and 20 medium to large mammals (Appendix D). Also included in this list is one non-native species, the feral dog. Quitobaquito plays an important role in the high mammal diversity at the monument by providing the largest source of perennial water in the region. Quitobaquito is an important resource for bats that use open water to hunt for insects and is the only site in the monument were the desert shrew is located (Cockrum and Petryszyn 1986). Night blooming cacti are another important resource, including organ pipe cactus, which provide nectar for the endangered southern (lesser) long-nosed bat.

Two large mammals that are found at the monument are uncommon in Arizona: the Sonoran pronghorn and desert bighorn sheep. The pronghorn is believed to be an occasional visitor to the monument and the desert bighorn sheep is found in very small numbers in the Diablo, Puerto Blanco, and Ajo mountains. Both species may occasionally be found at Quitobaquito.

\section{Inventory Completeness and Possible Species}

Based on the list of species and the many years of mammal surveys, most of the mammal species that occur at the monument have been recorded. There is one species, the feral burro (Equus asinus), that occurred at the monument in the recent past but is no longer present. There are several species that Cockrum and Petryszyn (1986) thought may occur in the monument:

BATS

Mexican long-tongued bat. Found in the very southern part of Arizona and south into Mexico, 
these bats prefer higher elevations in oak and pine but may be found in the higher elevations of Alamo Canyon.

Yuma myotis. This bat requires permanent water for insect prey, usually large bodies of water such as the Lower Colorado River. However, this species may be found at Quitobaquito Springs.

Fringed myotis. Usually found from chaparral to pine forests at elevations above $1,524 \mathrm{~m}$ (Hoffmeister 1986), this species may occasionally be found at the upper elevations of the Ajo mountains.

Eastern small-footed myotis. This species is usually found in oak and pinyon-juniper habitats, but may be found in the Ajo Mountains.

Eastern red bat. This bat would only be found in the winter at the monument in areas with tall trees.

Southern yellow bat. Similar to the eastern red bat, this species would be found in areas with trees.

\section{SMall Mammals}

Western and fulvous harvest mouse. Both species are normally associated with grasslands but may be found near Quitobaquito.
Deer mouse. This species would be found near intermittent streambeds or near other riparian areas. Canyon mouse. Found in rocky canyons, and volcanic areas.

House mouse. This species is associated with humans and will almost certainly be found at the monument in the future, most likely around the housing and administration offices.

Medium to Large Mammals

Black bear. Normally associated with woodlands, this species ranges throughout Arizona and may be found passing through the monument, most likely through the Ajo Mountains.

White-nosed coati. This species occurs in oak woodlands and along riparian areas and is most likely present in the Ajo Mountains.

Hooded skunk. This species is uncommon in southwestern Arizona, but its occurrence is a possibility.

Jaguar and jaguarundi. Both of these species are extremely rare in the region and occur to the south. A jaguar was collected from the Ajo Mountains in the 1910s (Hoffmeister 1986). 


\section{Chapter 7: Literature Cited}

Adams, L. W., and A. D. Geis. 1983. Effects of roads on small mammals. The Journal of Applied Ecology 20:403-415.

American Ornithologists' Union (AOU). 1998. Checklist of North American birds, seventh edition. American Ornithologists' Union and Allen Press Inc., Lawrence, KS.

American Ornithologists' Union (AOU). 2003. Forty-second supplement to the American Ornithologists' Union checklist of North American birds. Auk 117:847-858.

Baker, R. J., L. C. Bradley, R. D. Bradley, J. W. Dragoo, M. D. Engstrom, R. S. Hoffmann, C. A. Jones, F. Reid, D. W. Rice, and C. Jones. 2003. Revised checklist of North American mammals north of Mexico, 2003. Occasional Papers of the Museum of Texas Tech University 229:1-23.

Barnett, J. J., and D. Sharrow. 1992. Water resources management plan for Organ Pipe Cactus National Monument. U.S. Department of the Interior, National Park Service, Western Region, Denver, CO.

Bennett, P. S., and M. R. Kunzmann. 1987. Organ Pipe Cactus National Monument, Biosphere Reserve, Sensitive Ecosystems Program. Special Report No. 7. Cooperative National Park Studies Unit, University of Arizona, Tucson, AZ.

Bennett, P. S., and M. R. Kunzmann. 1989. A history of the Quitobaquito resource management area, Organ Pipe Cactus National Monument, Arizona. Technical Report No. 26. Cooperative National Park Resources Studies Unit, University of Arizona, Tucson, AZ.

Bennett, P. S., R. R. Johnson, and M. M. McCarthy. 1990. Assessment of scientific information and activities at Organ Pipe Cactus National Monument, Biosphere Reserve. Special Report No. 10. Cooperative National Park Resources Studies Unit, University of Arizona, Tucson, AZ.
Benson, L. A., B. Alberti, C. Gordon, A. Whalon, and T. Wood. 2001. Summary report of the southern Arizona/Sonora MAPS project for 1997-2000. Unpublished report by the National Park Service, Southern Arizona Office, Phoenix, AZ.

Bock, C. E., J. H. Bock, K. L. Jepson, and J. C. Ortega. 1986. Ecological effects of planting African lovegrasses in Arizona. National Geographic Research 2:456-463.

Bowers, J. E. 1980. Flora of Organ Pipe Cactus National Monument. Journal of the ArizonaNevada Academy of Science 15:1-11, 33-47.

Bowers, J. E. 1990. Vegetation change at Organ Pipe Cactus National Monument. Pp. 85-132. In P. S Bennett, R. R. Johnson, and M. M. McCarthy, editors. Assessment of scientific information and activities at Organ Pipe Cactus National Monument, Biosphere Reserve. Special Report No. 10. Cooperative National Park Resources Studies Unit, University of Arizona, Tucson, AZ.

Brown, B. 1991. Land use trends surrounding Organ Pipe Cactus National Monument. Technical Report No. 39. Cooperative National Park Resources Studies Unit, University of Arizona, Tucson, AZ.

Brown, B. T., R. R. Johnson, and K. Groschupf. 1985. A checklist of birds of Organ Pipe Cactus National Monument. Southwest Parks and Monuments Association, Tucson, AZ.

Brown, B. T., and P. L. Warren. 1986. A descriptive analysis of woody riparian vegetation at Quitobaquito Springs oasis, Organ Pipe Cactus National Monument, Arizona. Technical Report No. 19. Cooperative National Park Resources Studies Unit, University of Arizona, Tucson, AZ.

Carrico, J. W. 1969. Bighorn status at Organ Pipe Cactus National Monument. Desert Bighorn Council Transactions 8:64-67.

Carruth, R. L. 1996. Hydrogeology of the Quitobaquito Springs and La Abra Plain Area, 
Organ Pipe Cactus National Monument, Arizona, and Sonora, Mexico. Unpublished report by the United States Geological Survey, Tucson, AZ.

Chamberlin, E. 1972. Soil survey: A special report; Organ Pipe Cactus National Monument, Pima County, Arizona. U.S. Department of Agriculture, Soil Conservation Service, Phoenix, AZ.

Cockrum, E. L. 1981. Bat populations and habitats at the Organ Pipe Cactus National Monument. Technical Report No. 7. Cooperative National Park Resources Studies Unit, University of Arizona, Tucson, AZ.

Cockrum, E. L., editor. 1984. Reference manual: mammals of the Organ Pipe Cactus National Monument. Unpublished report to Organ Pipe Cactus National Monument, Ajo, AZ.

Cockrum, E. L. 1990. Some comments concerning recent mammals of Organ Pipe Cactus National Monument. Pp. 49-55. In P. S. Bennett, R. R. Johnson, and M. M. McCarthy, editors. Assessment of scientific information and activities at Organ Pipe Cactus National Monument, Biosphere Reserve. Special Report No. 10. Cooperative National Park Resources Studies Unit, University of Arizona, Tucson, AZ.

Cockrum, E. L., and Y. Petryszyn. 1986. Mammals of the Organ Pipe Cactus National Monument. Special Report No. 5. Cooperative National Park Resources Studies Unit, University of Arizona, Tucson, AZ.

Connor, C., and P. C. Rosen. 1996. Pp. 53-86. In A. Pate, editor. Organ Pipe Cactus National Monument Ecological Monitoring Program, annual report 1996. Organ Pipe Cactus National Monument, Ajo, AZ.

Coss, H. T. 1964. Status of the bighorn sheep in Organ Pipe Cactus National Monument. Desert Bighorn Council Transactions 8:117-121.

Cross, J. 1977. Unpublished note to Terry Peters, Organ Pipe Cactus National Monument Resource Management Specialist.
Cunningham, W. 1969. Bird checklist for Organ Pipe Cactus National Monument, Arizona. Unpublished list to Organ Pipe Cactus National Monument, Ajo, AZ.

Cunningham, W. 1971. Bird checklist for Organ Pipe Cactus National Monument, Arizona. Unpublished list to Organ Pipe Cactus National Monument, Ajo, AZ.

D’Antonio, C. M., and P. M. Vitousek. 1992. Biological invasions by exotic grasses, the grass fire cycle, and global change. Annual Review of Ecology and Systematics 23:63-87.

Douglas, C. L. 1975. A preliminary census of desert bighorn sheep in Organ Pipe Cactus National Monument. Contribution No. 8. Cooperative National Park Resources Studies Unit, University of Nevada, Las Vegas, NV.

Douglas, M. R., M. E. Douglas, and P. C. Brunner. 2001. Population estimates, movements, and size structure of the endangered Quitobaquito pupfish, Cyprinodon macularius eremus. Southwestern Naturalist 46:141-150.

Felger, R. S. 1990. Non-native plants of Organ Pipe Cactus National Monument, Arizona. Technical Report No. 31. Cooperative National Park Resources Studies Unit, University of Arizona, Tucson, AZ.

Felger, R. S., P. L. Warren, L. S. Anderson, and G. P. Nabhan. 1992. Vascular plants of a desert oasis: Flora and ethnobotany of Quitobaquito, Organ Pipe Cactus National Monument, Arizona. Proceedings of the San Diego Society of Natural History 8:1-39.

Flora of North America Editorial Committee. 1993. Flora of North America: North of Mexico. Oxford University Press, New York, NY.

Forman, R. T. T., and L. E. Alexander. 1998. Roads and their major effects. Annual Review of Ecology and Systematics 29:207-231.

Gloyd, H. K. 1937. A herpetological consideration of faunal areas in southern Arizona. Bulletin of the Chicago Academy of Sciences 5:79-136.

Groschupf, K. D., B. T. Brown, and R. R. Johnson. 1988. An annotated checklist of the birds of 
Organ Pipe Cactus National Monument, Arizona. Southwest Parks and Monuments Association, Tucson, AZ.

Halterman, M. D., S. Allen, and S. A. Laymon. 1999. Assessing the impact of brown-headed cowbird parasitism in eight National Parks. Studies in Avian Biology 18:153-159

Halvorson, W. L., and P. Guertin. 2003. USGS Weeds in the west project: status of introduced plants in southern Arizona parks. USGS, SBSC Sonoran Desert Research Station, University of Arizona, Tucson, AZ.

Hardy, P. C., D. J. Griffin, A. J. Kuenzi, and M. L. Morrison. 2004. Occurrence and habitat use of passage of Neotropical migrants in the Sonoran Desert. Western North American Naturalist 64:59-71.

Hendrickson, D. A., and A. V. Romero. 1989. Conservation status of Desert Pupfish, Cyprinodon macularius, in Mexico and Arizona. Copeia 1989:478-483.

Henry, R. S., and L. K. Sowls. 1980. White-tailed deer of the Organ Pipe Cactus National Monument, Arizona. Technical Report No. 6. Cooperative National Park Resources Studies Unit, University of Arizona, Tucson, AZ.

Hensley, M. M. 1950. Results of a herpetological reconnaissance in extreme southwestern Arizona and adjacent Sonora, with a description of a new subspecies of the Sonoran whipsnake, Masticophis bilineatus. Transactions of the Kansas Academy of Science 53:270-288.

Hensley, M. M. 1954. Ecological relationships of the breeding bird population of the desert biome in Arizona. Ecological Monographs 24:185-208.

Hensley, M. M. 1959. Notes on the nesting of selected species of birds of the Sonoran Desert. The Wilson Bulletin 71:86-92.

Heritage Data Management System (HDMS). 2004. Arizona Game and Fish Department. Accessed 5 March from: http://www.gf.state.az.us/w_c/edits/ hdms_species_lists.html.
Hoffmeister, D. F. 1986. Mammals of Arizona. The University of Arizona Press, Tucson, AZ.

Hubbard, J. A., T. M. Mau-Crimmins, B. F. Powell, E. W. Albrecht, N. Chambers, and L. Carder. 2003. National Park Service Sonoran Desert Network monitoring plan: Phase II. Sonoran Desert Network, Tucson, AZ.

Huey, L. M. 1942. A vertebrate faunal survey of the Organ Pipe Cactus National Monument, Arizona. Transactions of the San Diego Society of Natural History 32:353-376.

Hungerford, R. 1976. An evaluation of feral burros at Organ Pipe Cactus National Monument. Unpublished report by National Park Resources Studies Unit, University of Arizona, Tucson, AZ.

Johnson. R. R. 1995. Special-status avian species monitoring protocol for the Ecological Monitoring Program in Organ Pipe Cactus National Monument, Arizona. In Organ Pipe Cactus National Monument ecological monitoring program monitoring protocol manual. Special Report 11. Cooperative Park Studies Unit, University of Arizona, Tucson, AZ.

Johnson, R. R., B. T. Brown, and S. Goldwasser. 1983. Avian use of Quitobaquito Springs Oasis, Organ Pipe Cactus National Monument, Arizona. Technical Report No. 13. Cooperative National Park Resources Studies Unit, University of Arizona, Tucson, AZ.

Kingsley, K. J. 1995. Invertebrate monitoring protocol for the Ecological Monitoring Program in Organ Pipe Cactus National Monument, Arizona. In Organ Pipe Cactus National Monument Ecological Monitoring Program monitoring protocol manual. Report No. 11. Cooperative Park Studies Unit Special, University of Arizona, Tucson, AZ.

Kingsley, K. J. 1998. Invertebrates of Organ Pipe Cactus National Monument, Arizona. Technical Report No. 60. Cooperative National Park Resources Studies Unit, University of Arizona, Tucson, AZ. 
Kingsley, K. J., R. A. Bailowitz, and R. L. Smith. 1987. A preliminary investigation of the arthropod fauna of Quitobaquito Springs area, Organ Pipe Cactus National Monument, Arizona. Technical Report No. 23. Cooperative National Park Resources Studies Unit, University of Arizona, Tucson, AZ.

Larsen, E., and C. Olson. 1997. Aquatic Coleoptera and Hemiptera of Organ Pipe Cactus National Monument, Arizona. Entomological News 108:34-42.

Latta, M. J., C. J. Beardmore, and T. E. Corman. 1999. Arizona Partners in Flight conservation plan. Technical Report 142. Nongame and Endangered Wildlife Program, Arizona Game and Fish Department, Phoenix, AZ.

Lowe, C. H. 1990. A 50-year summary for the herpetofauna of Organ Pipe Cactus National Monument, Arizona (1932-1982). Pp. 63-73. In P. S. Bennett, R. R. Johnson, and M. M. McCarthy, editors. Assessment of scientific information and activities at Organ Pipe Cactus National Monument, Biosphere Reserve. Special Report No. 10. Cooperative National Park Resources Studies Unit, University of Arizona, Tucson, AZ.

Lowe, C. H., and P. C. Rosen. 1991. Checklist of the amphibians and reptiles at Organ Pipe Cactus National Monument. Southwest Parks and Monuments Association, Tucson, AZ.

Lowe, C. H., and W. R. Supernaugh. 1953. Checklist for the amphibians and reptiles at Organ Pipe Cactus National Monument. Organ Pipe Cactus National Monument, Ajo, AZ.

Lowe, C. H., E. B. Wirt, and P. C. Rosen. 1995. Vegetation structure and diversity in natural communities monitoring protocol for the Ecological Monitoring Program in Organ Pipe Cactus National Monument, Arizona. In Organ Pipe Cactus National Monument Ecological Monitoring Program monitoring protocol manual. Special Report 11. Cooperative Park Studies Unit, University of Arizona, Tucson, AZ.
Lunsford, H. F., and R. Lapidus. 1977. Reptiles and amphibians of Organ Pipe Cactus National Monument. Unpublished report to Organ Pipe Cactus National Monument, Ajo, AZ.

Luz, G. A., and J. B. Smith. 1976. Reactions of pronghorn antelope to helicopter overflight. Journal of Acoustical Society of America 59:1514-1515.

McDougall, W. B. 1945. Checklist of the known plants of Organ Pipe Cactus National Monument. Unpublished list to Organ Pipe Cactus National Monument, Ajo, AZ.

McEachern, K. 2000. Channel Islands National Park landbird monitoring program review, April 18-19, 2000. Unpublished report. Accessed on 5 October 2005 from: http://www.werc.usgs.gov/chis/ChannelIslands NPLandbirdProgramReview.pdf.

Mearns, E. A. 1907. Mammals of the Mexican boundary of the United States. A descriptive catalogue of the species of mammals occurring in that region; with a general summary of the natural history, and a list of trees. United States National Museum Bulletin 56. Washington, DC.

Miller, R. R. 1990. Status of the classification of the Quitobaquito pupfish. Pp. 75-81. In P. S. Bennett, R. R. Johnson, and M. M. McCarthy, editors. Assessment of scientific information and activities at Organ Pipe Cactus National Monument, Biosphere Reserve. Special Report No. 10. Cooperative National Park Resources Studies Unit, University of Arizona, Tucson, AZ.

Missouri Botanical Gardens (MBG). No date. W3 Trpicos website. http://mobot.mobot.org/ W3T/Search/vast.html.

Naeem, S., L. J. Thompson, T. H. Jones, J. H. Lawton, S. P. Lawler, and R. M. Woodfin. 1996. Changing community composition and elevated CO2. Pp. 93-100. In C. Korner, and F. A. Bazzaz, editors. Carbon dioxide, populations, and communities. Academic Press, San Diego, CA. 
National Audubon Society. 2005. Christmas bird count. Accessed on August 24, 2005 from: http://www.audubon.org/bird/cbc/index.html.

National Biological Service (NBS). 1995. Organ Pipe Cactus National Monument ecological monitoring program monitoring protocol manual. Special Report 11. Cooperative Park Studies Unit, University of Arizona, Tucson, AZ.

National Park Service (NPS). 1992. NPS-75: Natural resources inventory and monitoring guidelines. U.S. Dept. of Interior, Washington, D.C.

National Park Service (NPS). 1994a. Natural and cultural resources management plan for Organ Pipe Cactus National Monument. Organ Pipe Cactus National Monument, Ajo, AZ.

National Park Service (NPS). 1994b. Report on effects of aircraft overflights on the National Park system. Report to Congress. Prepared pursuant to Public Law 100-91, The National Parks Overflights Act of 1987.

National Park Service (NPS). 1997. General management plan, development concept plan, and environmental impact statement. Organ Pipe Cactus National Monument, Ajo, AZ.

National Park Service (NPS). 1998a. Organ Pipe Cactus National Monument Ecological Monitoring Program Annual Report 1994. Organ Pipe Cactus National Monument, Ajo, AZ.

National Park Service (NPS). 1998b. Organ Pipe Cactus National Monument Ecological Monitoring Program Annual Report 1995. Organ Pipe Cactus National Monument, Ajo, AZ.

National Park Service (NPS). 2003a. Resource issues in southern U.S. border parks from drug trafficking and undocumented alien activity. U.S. Department of the Interior, Southern Arizona Office, Phoenix, AZ.

National Park Service (NPS). 2003b. Proposed vehicle barrier environmental assessment. Organ Pipe Cactus National Monument/ Coronado National Memorial. U.S. Department of the Interior, Washington, D.C.
National Park Service (NPS). 2005. NPS visitation database reports. Accessed on 11 August 2004 from: http://www2.nature.nps. gov/NPstats/npstats.cfm.

Noon, B. R. 2003. Conceptual issues in monitoring ecological resources. In D. E. Busch and J. C. Trexler, editors. Monitoring ecosystems: Interdisciplinary approaches for evaluating ecoregional initiatives. Island Press, Washington, D.C.

Office of Technology Assessment (OTA). 1993. Harmful non-indigenous species in the United States. OTA-F-565, U.S. Government Printing Office, Washington, D.C.

Olsen, R. W. 1970. Secondary habitat selection in the white-throated woodrat (Neotoma albigula). Ph.D. Dissertation from the University of Wisconsin, Madison, WI.

Oxley, D. J., M. B. Fenton, and G. R. Carmody. 1974. The effects of roads on populations of small mammals. The Journal of Applied Ecology 11:51-59.

Parker, K. C. 1986. Partitioning and foraging space and nest sites in a desert shrubland bird community. The American Midland Naturalist 115:255-267.

Parker, K. C. 1991. Topography, substrate, and vegetation patterns in the northern Sonoran Desert. Journal of Biogeography 18:151-163.

Pate, A., editor. 1999. Organ Pipe Cactus National Monument Ecological Monitoring Program, annual report 1996. National Park Service, Ajo, AZ.

Pate, A., and J. Petterson. 1999. Bats. In A. Pate, editor. Organ Pipe Cactus National Monument Ecological Monitoring Program, annual report 1996. National Park Service, Ajo, AZ.

Pate, A. C., Y. Petryszyn, and J. Petterson. 1999. Monitoring use of surface water by bats at Organ Pipe Cactus National Monument. In L. Benson and B. Gebow, editors. A century of parks in southern Arizona: second conference on research and resource management in southern Arizona National Parks, extended abstracts. National Park Service, Southern 
Arizona Office and USGS Sonoran Desert Field Station, University of Arizona, Tucson, AZ.

Pearson, G., and C. W. Connor. 2000. The Quitobaquito desert pupfish, an endangered species within Organ Pipe Cactus National Monument: Historical significance and management challenges. Natural Resources Journal 40:379-410.

Petterson, J. 1999. Nocturnal rodents. In A. Pate, editor. Organ Pipe Cactus National Monument Ecological Monitoring Program, annual report 1996. National Park Service, Ajo, AZ. Petryszyn, Y. 1995a. Small nocturnal mammals monitoring protocol for the Ecological Monitoring Program in Organ Pipe Cactus National Monument, Arizona. In Organ Pipe Cactus National Monument Ecological Monitoring Program monitoring protocol manual. Special Report 11. Cooperative Park Studies Unit, University of Arizona, Tucson, AZ.

Petryszyn, Y. 1995a. Small nocturnal mammals monitoring protocol for the Ecological Monitoring Program in Organ Pipe Cactus National Monument, Arizona. In Organ Pipe Cactus National Monument Ecological Monitoring Program monitoring protocol manual. Special Report 11. Cooperative Park Studies Unit, University of Arizona, Tucson, AZ.

Petryszyn, Y. 1995b. Bat monitoring protocol for the Ecological Monitoring Program in Organ Pipe Cactus National Monument, Arizona. In Organ Pipe Cactus National Monument Ecological Monitoring Program monitoring protocol manual. Special Report 11. Cooperative Park Studies Unit, University of Arizona, Tucson, AZ.

Petryszyn, Y., and E. L. Cockrum. 1990. Mammals of the Quitobaquito Management Area, Organ Pipe Cactus National Monument, Arizona. Technical Report No. 36. Cooperative National Park Resources Studies Unit, University of Arizona, Tucson, AZ.
Petryszyn, Y., and S. Russ. 1996. Nocturnal rodent population densities and distribution at Organ Pipe Cactus National Monument, Arizona. Technical Report No. 52.

Cooperative National Park Resources Studies Unit. University of Arizona, Tucson, AZ.

Petryszyn, Y., S. Russ, and A. C. Pate. 1998. Bat monitoring at Quitobaquito Pond, Organ Pipe Cactus National Monument, Arizona. In T. J. Tibbitts and G. J. Maender, editors. First conference on research management in southern Arizona national park areas: Extended abstracts. Cooperative National Park Resources Studies Unit, University of Arizona, Tucson, AZ.

Phillips, A. R., and W. M. Pulich. 1948. Nesting birds of the Ajo Mountains region, Arizona. The Condor 50:271-272.

Pinkava, D. J., M. A. Baker, R. A. Johnson, N. Thrushell, G. A. Ruffner, R. S. Felger, and R. K. VanDevender. 1992. Additions, notes, and chromosome numbers for flora of vascular plants of Organ Pipe Cactus National Monument, Arizona. Journal of the ArizonaNevada Academy of Science 24:13-18.

Powell, B. F., E. W. Albrecht, W. L. Halvorson, C. A. Schmidt, P. Anning, and K. Docherty. 2005a. Vascular plant and vertebrate inventory of Tumacácori National Historical Park. USGS Open-File Report 2005-1142. U.S. Geological Survey, Southwest Biological Science Center, Sonoran Desert Research Station, University of Arizona, Tucson, AZ.

Powell, B. F., C. A. Schmidt, W. L. Halvorson, and P. Anning. 2005b. Vascular plant, bird, and mammal inventory of Fort Bowie National Historic Site. Final report to the National Park Service, Sonoran Desert Inventory and Monitoring Program, Tucson, AZ.

Powell, B. F., C. A. Schmidt, and W. L. Halvorson. 2006. Vascular plant and vertebrate inventory of Saguaro National Park, Rincon Mountain District. USGS OFR 2006-1075. USGS, Southwest Biological Science Center, Sonoran Desert Research Station, University of Arizona, Tucson, AZ. 
Rankin, A. G. 1991. Archaeological survey in Organ Pipe Cactus National Monument: 1991 progress report. Unpublished report to Organ Pipe Cactus National Monument by the Western Archaeological and Conservation Center, National Park Service, Tucson, AZ.

Rappole, J. H. 1995. The ecology of migrant birds: a neotropical perspective. Smithsonian Institution Press, Washington, D.C.

Rosen, P. C. 2000. A monitoring study of vertebrate community ecology in the northern Sonoran Desert, Arizona. PhD. Dissertation. Department of Ecology and Evolutionary Biology, University of Arizona, Tucson, AZ.

Rosen, P. C., and C. H. Lowe. 1994. Highway mortality of snakes in the Sonoran Desert of southern Arizona. Biological Conservation 68:143-148.

Rosen, P. C., and C. H. Lowe. 1995. Lizard monitoring protocol for the Ecological Monitoring Program in Organ Pipe Cactus National Monument. In Organ Pipe Cactus National Monument Ecological Monitoring Program monitoring protocol manual. Special Report 11. Cooperative Park Studies Unit, University of Arizona, Tucson, AZ.

Rosen, P. C., and C. H. Lowe. 1996. Ecology of the amphibians and reptiles at Organ Pipe Cactus National Monument, Arizona. Technical Report No. 53. Cooperative Park Resources Studies Unit, University of Arizona, Tucson, AZ.

Rosenberg, K. V., R. D. Ohmart, W. C. Hunter, and B. W. Anderson. 1991. Birds of the lower Colorado River Valley. University of Arizona Press, Tucson, AZ.

Rowlands, P. 1999. Introduction to ecological monitoring. In A. Pate, editor. Organ Pipe Cactus National Monument Ecological Monitoring Program, annual report 1996. Organ Pipe Cactus National Monument, Ajo, AZ.

Ruffner Associates. 1995. Special-status plants monitoring protocol for the Ecological Monitoring Program in Organ Pipe Cactus
National Monument, Arizona. In Organ Pipe Cactus National Monument Ecological Monitoring Program monitoring protocol manual. Special Report 11. Cooperative Park Studies Unit, University of Arizona, Tucson, AZ.

Rutman, S. 2005. A checklist of vascular plants of Organ Pipe Cactus National Monument. Unpublished report.

Sauer, J. R., J. E. Hines, and J. Fallon. 2005. The North American Breeding Bird Survey, results and analysis 1966-2004. Version 2005.2. Patuxtant Wildlife Research Center, Laurel MD. Accessed on 10 October 2005 from: http://www.mbr-pwrc.usgs.gov/bbs/bbs.html.

Sprouse, T., R. Emanuel, and B. Tellman. 2002. Surface water quality monitoring overview and assessment. Unpublished report to the Sonoran Desert Network Inventory and Monitoring Program, National Park Service, Tucson, AZ.

Stebbins, R. C. 2003. A field guide to western reptiles and amphibians. Third edition. Houghton Mifflin, New York, NY.

Steenbergh, W. F., and W. E. Hoy. 1963. Checklist of birds of Organ Pipe Cactus National Monument. Unpublished report to Organ Pipe Cactus National Monument, Ajo, AZ.

Steenbergh, W. F., and P. L. Warren. 1977. Preliminary ecological investigation of natural community status at Organ Pipe Cactus National Monument. Technical Report No. 3. Cooperative Park Resources Studies Unit, University of Arizona, Tucson, AZ.

Suzan, H., G. Malda, D. T. Patten, and G. P. Nabhan. 1997. Exploitation and conservation of ironwood (Olneya tesota) in the Sonoran Desert. Ecological Applications 7:948-957.

Suzan, H., G. Malda, D. T. Patten, and G. P. Nabhan. 1999. Effects of exploitation and park boundaries on legume trees in the Sonoran Desert. Conservation Biology 13:1497-1501. 
Tallman, D. A. 1970. The birds of Quitobaquito and Williams' springs, Arizona: A list of birds observed in spring 1970. Unpublished report to Organ Pipe Cactus National Monument, Ajo, AZ.

Tibbitts, T. A. 1999a. Lesser long-nosed bat. In A. Pate, editor. Organ Pipe Cactus National Monument Ecological Monitoring Program, annual report 1996. Organ Pipe Cactus National Monument, Ajo, AZ.

Tibbitts, T. A. 1999b. Desert pupfish. In A. Pate, editor. Organ Pipe Cactus National Monument Ecological Monitoring Program, annual report 1996. Organ Pipe Cactus National Monument, Ajo, AZ.

Tibbitts, T. A. 2003. Avian monitoring 1997-2003. Unpublished report to Organ Pipe Cactus National Monument, Ajo, AZ.

Tibbitts, T. A., and L. L. Dickson. 2005. An update to: "An annotated checklist of the birds of Organ Pipe Cactus National Monument." Unpublished annotated species list for Organ Pipe Cactus National Monument, Ajo, AZ.

Tibbitts, T., A. Pate, Y. Petryszyn, and B. Barns. 2002. Determining foraging and roosting areas for Underwood's mastiff bat (Eumops underwoodi) using radiotelemetry, at Organ Pipe Cactus National Monument, Arizona. Final summary report to Organ Pipe Cactus National Monument, Ajo, AZ.

Trombulak, S. C., and C. A. Frissell. 2000. Review of ecological effects of roads on terrestrial and aquatic communities. Conservation Biology 14:18-30.

United States Department of Agriculture (USDA). No date. The PLANTS Database, Version 3.5 (http://plants.usda.gov). National Plant Data Center, Natural Resources Conservation Service, Baton Rouge, LA.
United States Fish and Wildlife Service (USFWS). 2002. Birds of conservation concern 2002. Division of Bird Management, Arlington, VA.

Warren, P. L., and L. S. Anderson. 1995. Natural community grazing-recovery monitoring protocol for the Ecological Monitoring Program in Organ Pipe Cactus National Monument, Arizona. In Organ Pipe Cactus National Monument Ecological Monitoring Program monitoring protocol manual. Special Report 11. Cooperative Park Studies Unit, University of Arizona, Tucson, AZ.

Warren, P. L., B. K. Mortenson, B. D. Treadwell, J. E. Bowers, and K. L. Reichhardt. 1981. Vegetation of Organ Pipe Cactus National Monument. Technical Report No. 8. Cooperative National Park Resources Studies Unit, University of Arizona, Tucson, AZ.

Weisenberger, M. E., P. R. Krausman, M. C. Wallace, D. W. DeYoung, and O. E. Maughan. 1996. Effects of simulated jet aircraft noise on heart rate and behavior of desert ungulates. Journal of Wildlife Management 60:52-61.

Western Regional Climate Center (WRCC). 2005. Arizona climate summaries from Organ Pipe Cactus National Monument, Arizona.

Accessed on 4 June 2005 from: http://www.wrcc.dri.edu/summary/ climsmnm.html

Wilt, R. A. 1976. Birds of Organ Pipe Cactus National Monument. Popular Series No. 18. Southwest Parks and Monuments Association, Globe, AZ.

Wirt, E. B., P. A. Holm, and R. H. Robichaux. 1999. Survey and monitoring of the desert tortoise, Gopherus agassizii, at Organ Pipe Cactus National Monument. Final Report to National Park Service, Organ Pipe Cactus National Monument. 
Appendix A. Plant species that have been observed or collected at Organ Pipe Cactus NM based on the list by Rutman (2005). Species in bold-faced type are non-native.

\begin{tabular}{|c|c|c|}
\hline Family & Scientific name & Common name \\
\hline \multirow[t]{7}{*}{ Acanthaceae } & Anisacanthus thurberi (Torrey) A. Gray & Thurber's desert honeysuckle \\
\hline & Carlowrightia arizonica A. Gray & Arizona wrightwort \\
\hline & Dicliptera resupinata (Vahl) de Jussieu & Arizona foldwing \\
\hline & Justicia californica (Bentham) D.N. Gibson & beloperone \\
\hline & Justicia candicans (Nees) L.D. Benson & Arizona water-willow \\
\hline & Justicia longii Hilsenbeck & longflower tubetongue \\
\hline & Ruellia nudiflora (Engelmann \& A. Gray) Urban & violet wild petunia \\
\hline \multirow[t]{4}{*}{ Agavaceae } & Agave *ajoenesis W.C. Hodgson & \\
\hline & Agave deserti Engelmann ssp. simplex Gentry & desert agave \\
\hline & Agave schottii Engelmann & Schott's century plant \\
\hline & Yucca baccata Torrey & banana yucca \\
\hline \multirow[t]{3}{*}{ Aizoaceae } & Mesembryanthemum crystallinum Linnaeus & common iceplant \\
\hline & Mesembryanthemum nodiflorum Linnaeus & slenderleaf iceplant \\
\hline & Trianthema portulacastrum Linnaeus & desert horsepurslane \\
\hline \multirow[t]{6}{*}{ Amaranthaceae } & Amaranthus albus Linnaeus & prostrate pigweed \\
\hline & Amaranthus fimbriatus (Torrey) Bentham ex S. Watson & fringed amaranth \\
\hline & Amaranthus palmeri S. Watson & carelessweed \\
\hline & Amaranthus $x$ tucsonensis Henrickson & \\
\hline & Gomphrena sonorae Torrey & Sonoran globe amaranth \\
\hline & Tidestromia lanuginosa (Nuttall) Standley & woolly tidestromia \\
\hline Anacardiaceae & Rhus aromatica Aiton var. trilobata (Nuttall) A. Gray ex S. Watson & skunkbush sumac \\
\hline \multirow[t]{5}{*}{ Apiaceae } & Bowlesia incana Ruiz \& Pavon & hoary bowlesia \\
\hline & Daucus pusillus Michaux & American wild carrot \\
\hline & Lomatium nevadensis (S. Watson) Coulter \& Rose & Nevada biscuitroot \\
\hline & Spermolepis echinata (Nuttall) Heller & bristly scaleseed \\
\hline & Yabea microcarpa (Hooker \& Arnott) Koso-Poljanski & false carrot \\
\hline Apocynaceae & Haplophyton crooksii L.D. Benson & cockroachplant \\
\hline Aristolochiaceae & Aristolochia watsonii Wooton \& Standley & Watson's dutchman's pipe \\
\hline \multirow[t]{7}{*}{ Asclepiadaceae } & Asclepias linaria Cavanilles & pineneedle milkweed \\
\hline & Asclepias nyctaginifolia A. Gray & Mojave milkweed \\
\hline & Asclepias subulata Decaisne & rush milkweed \\
\hline & Funastrum cynanchoides (Decaisne) Schlechter ssp. hartwegii (Vail) Krings & Hartweg's twinevine \\
\hline & Matelea cordifolia (A. Gray) Woodson & Sonoran milkvine \\
\hline & Matelea parvifolia (Torrey) Woodson & spearleaf \\
\hline & Metastelma arizonicum A. Gray & Arizona swallow-wort \\
\hline \multirow[t]{15}{*}{ Asteraceae } & Acamptopappus sphaerocephalus (Harvey \& A. Gray) A. Gray & pygmyflower rockjasmine \\
\hline & Acourtia nana (A. Gray) Reveal \& R.M. King & dwarf desertpeony \\
\hline & Acourtia wrightii (A. Gray) Reveal \& R.M. King & brownfoot \\
\hline & Adenophyllum porophylloides (A. Gray) Strother & San Felipe dogweed \\
\hline & Ambrosia ambrosioides (Cavanilles) W.W. Payne & ambrosia leaf burr ragweed \\
\hline & Ambrosia confertiflora de Candolle & weakleaf burr ragweed \\
\hline & Ambrosia cordifolia (A. Gray) W.W. Payne & Tucson burr ragweed \\
\hline & Ambrosia deltoidea (Torrey) W.W. Payne & triangle burr ragweed \\
\hline & Ambrosia dumosa (A. Gray) W.W. Payne & burrobush \\
\hline & Artemisia dracunculoides Pursh & tarragon \\
\hline & Artemisia ludoviciana Nuttall ssp. albula (Wooton) D.D. Keck & white sagebrush \\
\hline & Baccharis brachyphylla A. Gray & shortleaf baccharis \\
\hline & Baccharis salicifolia (Ruiz \& Pavon) Persoon & mule's fat \\
\hline & Baccharis sarothroides A. Gray & desertbroom \\
\hline & Baileya multiradiata Harvey \& A. Gray & desert marigold \\
\hline
\end{tabular}




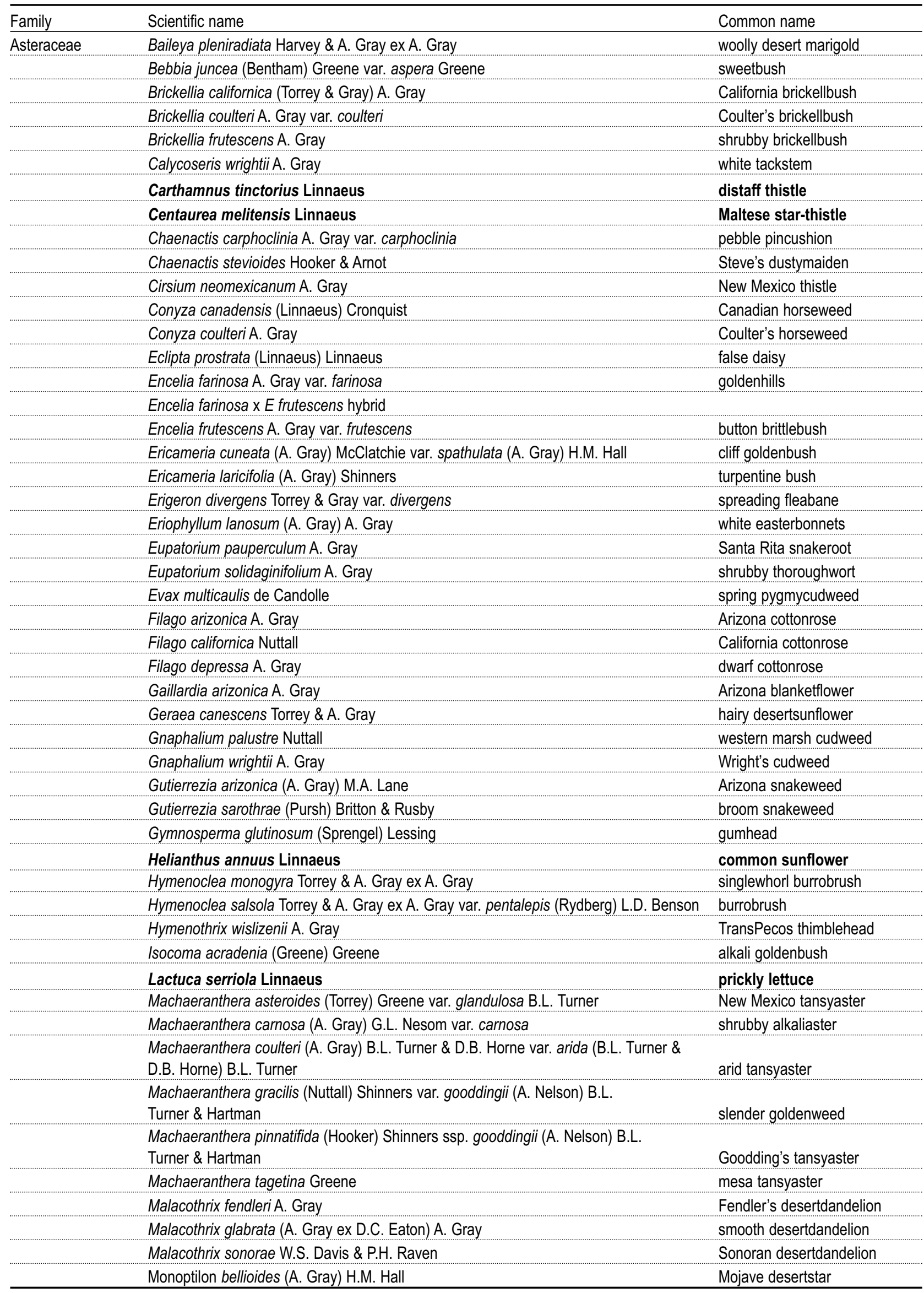




\begin{tabular}{|c|c|c|}
\hline Family & Scientific name & Common name \\
\hline \multirow[t]{33}{*}{ Asteraceae } & Packera quercetorum (Greene) C. Jeffrey & Oak Creek ragwort \\
\hline & Palafoxia arida B.L. Turner \& M.I. Morris var. arida & desert palafox \\
\hline & Parthenice mollis A. Gray & annual monsterwort \\
\hline & Pectis linifolia Linnaeus & romero macho \\
\hline & Pectis papposa Harvey \& A. Gray var. papposa & manybristle cinchweed \\
\hline & Perityle ajoensis T.K. Todsen & Ajo rockdaisy \\
\hline & Perityle emoryi Torrey & Emory's rockdaisy \\
\hline & Pleurocoronis laphamioides (Rose) R.M. King \& H. Robinson & \\
\hline & Pluchea odorata (Linnaeus) Cassini var. odorata & sweetscent \\
\hline & Pluchea sericea (Nuttall) Coville & arrowweed \\
\hline & Porophyllum gracile Bentham & slender poreleaf \\
\hline & Prenanthella exigua (A. Gray) Rydberg & brightwhite \\
\hline & Psilostrophe cooperi (A. Gray) Greene & whitestem paperflower \\
\hline & Rafinesquia californica Nuttall & California plumseed \\
\hline & Rafinesquia neomexicana A. Gray & New Mexico plumseed \\
\hline & Senecio flaccidus Lessing var. monoensis (Greene) B.L. Turner \& T.M. Barkley & Mono ragwort \\
\hline & Senecio lemmonii A. Gray & Lemmon's ragwort \\
\hline & Senecio mohavensis A. Gray & Mojave ragwort \\
\hline & Senecio quercetorum Greene & \\
\hline & Sonchus asper (Linnaeus) Hill & spiny sowthistle \\
\hline & Sonchus oleraceus Linnaeus & common sowthistle \\
\hline & Stephanomeria exigua Nuttall ssp. exigua & small wirelettuce \\
\hline & Stephanomeria pauciflora (Torrey) Nelson var. pauciflora & brownplume wirelettuce \\
\hline & Stylocline gnaphalioides Nuttall & mountain neststraw \\
\hline & Stylocline micropoides A. Gray & woollyhead neststraw \\
\hline & Thymophylla concinna (A. Gray) Strother & Sonoran pricklyleaf \\
\hline & Thymophylla pentachaeta (de Candolle) Small var. belenidium (de Candolle) Strother & fiveneedle pricklyleaf \\
\hline & Townsendia annua Beaman & annual Townsend daisy \\
\hline & Trichoptilium incisum (A. Gray) A. Gray & yellowdome \\
\hline & Trixis californica Kellogg var. californica & American threefold \\
\hline & Uropappus lindleyi (de Candolle) Nuttall & Lindley's silverpuffs \\
\hline & Viguiera parishii Greene & Parish's goldeneye \\
\hline & Zinnia acerosa (de Candolle) A. Gray & desert zinnia \\
\hline \multirow[t]{2}{*}{ Berberidaceae } & Berberis haematocarpa Wooton & red barberry \\
\hline & Berberis harrisoniana Kearney \& Peebles & Harrison's barberry \\
\hline Bignoniaceae & Chilopsis linearis (Cavanilles) Sweet ssp. arcuata (Fosberg) Henrickson & desert willow \\
\hline \multirow[t]{15}{*}{ Boraginaceae } & Amsinckia intermedia Fischer \& C.A. Meyer var. echinata (A. Gray) Wiggins & common fiddleneck \\
\hline & Amsinckia tessellata A. Gray & bristly fiddleneck \\
\hline & Cryptantha angustifolia (Torrey) Greene & Panamint cryptantha \\
\hline & Cryptantha barbigera (A. Gray) Greene & bearded cryptantha \\
\hline & Cryptantha maritima (Greene) Greene & Guadalupe cryptantha \\
\hline & Cryptantha pterocarya (Torrey) Greene var. cycloptera (Greene) J.F. Macbride & wingnut cryptantha \\
\hline & Harpogonella palmeri A Gray & Palmer's grapplinghook \\
\hline & Heliotropium curassavicum Linnaeus & salt heliotrope \\
\hline & Lappula occidentalis (S. Watson) Greene & flatspine stickseed \\
\hline & Pectocarya heterocarpa (I.M. Johnson) I. M. Johnson & chuckwalla combseed \\
\hline & Pectocarya platycarpa Munz \& I.M. Johnston & broadfruit combseed \\
\hline & Pectocarya recurvata I.M. Johnston & curvenut combseed \\
\hline & Plagiobothrys arizonicus (A. Gray) Greene & Arizona popcornflower \\
\hline & Plagiobothrys jonesii A. Gray & Mojave popcornflower \\
\hline & Tiquilia canescens (de Candolle) A.T. Richardson & woody crinklemat \\
\hline Brassicaceae & Boechera perennans (S. Watson) W.A. Weber & perennial rockcress \\
\hline
\end{tabular}




\begin{tabular}{|c|c|c|}
\hline Family & Scientific name & Common name \\
\hline \multirow[t]{20}{*}{ Brassicaceae } & Brassica nigra (Linnaeus) W.D.J. Koch & black mustard \\
\hline & Brassica tournefortii Gouan & Asian mustard \\
\hline & Caulanthus lasiophyllus (Hooker \& Arnott) Payson & California mustard \\
\hline & Descurainia pinnata (Walter) Britton & western tansymustard \\
\hline & Draba cuneifolia Nuttall ex Torrey \& A. Gray & wedgeleaf draba \\
\hline & \multicolumn{2}{|l|}{ Eruca sericea Bentham } \\
\hline & Erysimum capitatum (Douglas ex Hooker) Greene & sanddune wallflower \\
\hline & Lepidium densiflorum Schrader & common pepperweed \\
\hline & Lepidium lasiocarpum Nuttall & shaggyfruit pepperweed \\
\hline & Lepidium thurberi Wooton & Thurber's pepperweed \\
\hline & Lesquerella tenella A. Nelson & Moapa bladderpod \\
\hline & Lyrocarpa coulteri Hooker \& Harvey var. coulteri & Coulter's lyrepod \\
\hline & Rorippa microphylla (Boenn. ex Reichenb.) Hyl. ex A.\& D. Löve & onerow yellowcress \\
\hline & Schoenocrambe linearifolia (A. Gray) Rollins & slimleaf plainsmustard \\
\hline & Sisymbrium irio Linnaeus & London rocket \\
\hline & Sisymbrium orientale Linnaeus & Indian hedgemustard \\
\hline & Streptanthella longirostris (S. Watson) Rydberg & longbeak streptanthella \\
\hline & Streptanthus carinatus A. Gray & lyreleaf jewelflower \\
\hline & Thelypodium wrightii A. Gray ssp. wrightii & Wright's thelypody \\
\hline & Thysanocarpus curvipes Hooker & sand fringepod \\
\hline Burseraceae & Bursera microphylla A. Gray & elephant tree \\
\hline \multirow[t]{28}{*}{ Cactaceae } & Carnegia gigantea (Engelmann) Britton \& Rose & saguaro \\
\hline & $\begin{array}{l}\text { Cylindropuntia acanthocarpa (Engelmann \& J.M. Bigelow) F.M. Knuth var. } \\
\text { coloradensis (L.D. Benson) Pinkava }\end{array}$ & Colorado buckhorn cholla \\
\hline & $\begin{array}{l}\text { Cylindropuntia acanthocarpa (Engelmann \& J.M. Bigelow) Knuth var. major } \\
\text { (Engelmann \& J.M. Bigelow) Pinkava }\end{array}$ & buckhorn cholla \\
\hline & Cylindropuntia arbuscula (Engelmann) F. M. Knuth & Arizona pencil cholla \\
\hline & Cylindropuntia bigelovii (Engelmann) F. M. Knuth var. bigelovii & teddybear cholla \\
\hline & Cylindropuntia fulgida (Engelmann) F.M. Knuth var. fulgida & jumping cholla \\
\hline & $\begin{array}{l}\text { Cylindropuntia fulgida (Engelmann) F.M. Knuth var. mamillata (Schott ex Engelmann) } \\
\text { J.M. Coulter }\end{array}$ & jumping cholla \\
\hline & Cylindropuntia leptocaulis (de Candolle) F.M. Knuth & Christmas cactus \\
\hline & Cylindropuntia ramosissima (Engelmann) F.M. Knuth & branched pencil cholla \\
\hline & Cylindropuntia spinosior (Engelmann) F.M. Knuth & walkingstick cactus \\
\hline & Cylindropuntia versicolor (Engelmann ex J.M. Coulter) F.M. Knuth & staghorn cholla \\
\hline & Echinocereus engelmannii (Parry ex Englemann) Lemaire var. acicularis L.D. Benson & Engelmann's hedgehog cactus \\
\hline & Echinocereus nicholii (L.D. Benson) B.D. Parfitt & Nichol's hedgehog cactus \\
\hline & Echinocereus santaritensis W. Blum \& Rutow & Mojave mound cactus \\
\hline & $\begin{array}{l}\text { Echinocereus erectocentrus (J.M. Coulter) Britton \& Rose var. acunensis } \\
\text { (W.T. Marshall) Bravo }\end{array}$ & redspine fishhook cactus \\
\hline & Ferocactus cylindraceus (Engelmann) Orcutt & California barrel cactus \\
\hline & Ferocactus emoryi (Engelmann) Orcutt & Emory's barrel cactus \\
\hline & Ferocactus wislizeni (Englemann) Britton \& Rose & candy barrelcactus \\
\hline & Grusonia kunzei (Rose) Pinkava & devil's cholla \\
\hline & Grusonia parishii (Orcutt) Pinkava & matted cholla \\
\hline & Mammillaria grahamii Engelmann & Graham's nipple cactus \\
\hline & Mammillaria tetrancistra Engelmann & common fishhook cactus \\
\hline & Mammillaria thornberi Orcutt & Thornber's nipple cactus \\
\hline & Opuntia chlorotica Engelmann \& J.M. Bigelow & dollarjoint pricklypear \\
\hline & Opuntia engelmannii Salm-Dyck var. engelmannii & cactus apple \\
\hline & Opuntia engelmannii Salm-Dyck var. flavispina (L.D. Benson) Pinkava \& Parfitt & cactus apple \\
\hline & Opuntia engelmannii Salm-Dyck var. linguiformis (Griffiths) B.D. Parfitt \& Pinkava & cactus apple \\
\hline & Opuntia phaeacantha Englemann & tulip pricklypear \\
\hline
\end{tabular}




\begin{tabular}{|c|c|c|}
\hline Family & Scientific name & Common name \\
\hline \multirow[t]{5}{*}{ Cactaceae } & Pachycereus schottii (Engelmann) D.R. Hunt & senita cactus \\
\hline & Peniocereus greggii (Engelmann) Britton \& Rose var. transmontanus (Engelmann) & \\
\hline & Backeberg & nightblooming cereus \\
\hline & Peniocereus striatus (Brandegee) F. Buxbaum & gearstem cactus \\
\hline & Stenocereus thurberi (Engelmann) Buxbaum & organpipe cactus \\
\hline \multirow[t]{2}{*}{ Campanulaceae } & Nemacladus glanduliferus Jepson & glandular threadplant \\
\hline & Triodanis biflora (Ruiz \& Pavon) Greene & clasping Venus' looking-glass \\
\hline \multirow[t]{4}{*}{ Capparaceae } & Capparis atamisquea Kuntze & vomitbush \\
\hline & Polanisia dodecandra (Linnaeus) de Candolle ssp. trachysperma (Torrey \& A. Gray) & \\
\hline & H.H. Iltis & sandyseed clammyweed \\
\hline & Wislizenia refracta Engelmann ssp. refracta & spectacle fruit \\
\hline \multirow[t]{5}{*}{ Caryophyllaceae } & Achyronychia cooperi Torrey \& A. Gray & onyxflower \\
\hline & Cerastium texanum Britton & Texas chickweed \\
\hline & Herniaria hirsuta Linnaeus var. cinerea (de Candolle) Loret \& Barrandon & hairy rupturewort \\
\hline & Loeflingia squarrosa Nuttall & spreading pygmyleaf \\
\hline & Silene antirrhina Linnaeus & sleepy silene \\
\hline \multirow[t]{12}{*}{ Chenopodiaceae } & Atriplex canescens (Pursh) Nuttall var. canescens & fourwing saltbush \\
\hline & Atriplex elegans (Moquin-Tandon) D. Dietrich & wheelscale saltbush \\
\hline & Atriplex lentiformis (Torrey) S. Watson & big saltbush \\
\hline & Atriplex linearis S. Watson & thinleaf fourwing saltbush \\
\hline & Atriplex pacifica A. Nelson & Davidson's saltbush \\
\hline & Atriplex polycarpa (Torrey) S. Watson & cattle saltbush \\
\hline & Chenopodium murale Linnaeus & nettleleaf goosefoot \\
\hline & Chenopodium watsonii A. Nelson & Watson's goosefoot \\
\hline & Monolepis nuttalliana (Schultes) Greene & Nuttall's povertyweed \\
\hline & Nitrophylla occidentalis (Moquin-Tandon) S. Watson & boraxweed \\
\hline & Salsola tragus Linnaeus & prickly Russian thistle \\
\hline & Suaeda nigra (Rafinesque) J.F. Macbride & Mojave seablite \\
\hline Commelinaceae & Commelina erecta Linnaeus & whitemouth dayflower \\
\hline \multirow[t]{9}{*}{ Convulvulaceae } & Cuscuta californica Hooker \& Arnott & chaparral dodder \\
\hline & Cuscuta salina Engelmann & saltmarsh dodder \\
\hline & Cuscuta tuberculata Kunth & tubercle dodder \\
\hline & Cuscuta umbellata Kunth & flatglobe dodder \\
\hline & Evolvulus alsinoides Linnaeus var. angustifolia Torrey & slender dwarf morning-glory \\
\hline & Ipomoea costellata Torrey & crestrib morning-glory \\
\hline & Ipomoea cristulata Hallier & Transpecos morning-glory \\
\hline & Ipomoea hederacea Jacquin & ivyleaf morning-glory \\
\hline & Jacquemontia pringlei A. Gray & Pringle's clustervine \\
\hline \multirow[t]{3}{*}{ Crassulaceae } & Crassula connata (Ruiz \& Pavon) Berger & sand pygmyweed \\
\hline & Dudleya arizonica Rose & chalk dudleya \\
\hline & Graptopetalum rusbyi (Greene) Rose & $\begin{array}{l}\text { San Francisco River } \\
\text { leatherpetal }\end{array}$ \\
\hline Crossosomataceae & Crossosoma bigelovii S. Watson & ragged rockflower \\
\hline \multirow[t]{5}{*}{ Cucurbitaceae } & Brandegea bigelovii (S. Watson) Cogniaux & desert starvine \\
\hline & Cucurbita digitata A. Gray & fingerleaf gourd \\
\hline & Echinopepon wrightii (A. Gray) Watson & wild balsam apple \\
\hline & Marah gilensis (Greene) Greene & Gila manroot \\
\hline & Tumamoca macdougalii Rose & Tumamoc globeberry \\
\hline Cupressaceae & Juniperus coahuilensis (Martinez) Gaussen ex R.P. Adams & redberry juniper \\
\hline \multirow[t]{3}{*}{ Cyperaceae } & Cyperus laevigatus Linnaeus & smooth flatsedge \\
\hline & Cyperus mutisii (Kunth) Andersson & Mutis' flatsedge \\
\hline & Cyperus odoratus Linnaeus & fragrant flatsedge \\
\hline
\end{tabular}




\begin{tabular}{|c|c|c|}
\hline Family & Scientific name & Common name \\
\hline \multirow[t]{4}{*}{ Cyperaceae } & Cyperus squarrosus Linnaeus & bearded flatsedge \\
\hline & Eleocharis geniculata (Linnaeus) Roemer \& Schultes & Canada spikesedge \\
\hline & Eleocharis rostellata (Torrey) Torrey & beaked spikerush \\
\hline & Scirpus americanus Persoon & \\
\hline Ephedraceae & Ephedra aspera Engelmann ex S. Watson & rough jointfir \\
\hline \multirow[t]{25}{*}{ Euphorbiaceae } & Acalypha californica Bentham & California copperleaf \\
\hline & Croton sonorae Torrey & Sonoran croton \\
\hline & Ditaxis adenophora (A. Gray) Pax \& K. Hoffmann & desert silverbush \\
\hline & Ditaxis lanceolata (Bentham) Pax \& K. Hoffmann & narrowleaf silverbush \\
\hline & Ditaxis neomexicana (Muller Argoviensis) A. Heller & New Mexico silverbush \\
\hline & Euphorbia abramsiana Wheeler & Abrams' sandmat \\
\hline & Euphorbia albomarginata Torrey \& A. Gray & whitemargin sandmat \\
\hline & Euphorbia arizonica Engelmann & Arizona sandmat \\
\hline & Euphorbia capitellata Engelmann & head sandmat \\
\hline & Euphorbia eriantha Bentham & beetle spurge \\
\hline & Euphorbia florida Engelmann & Chiricahua Mountain sandmat \\
\hline & Euphorbia heterophylla Linnaeus & Mexican fireplant \\
\hline & Euphorbia hyssopifolia Linnaeus & hyssopleaf sandmat \\
\hline & Euphorbia melanadenia Torrey & squaw sandmat \\
\hline & Euphorbia micromera Boissier & Sonoran sandmat \\
\hline & Euphorbia pediculifera Engelmann var. pediculifera & Carrizo Mountain sandmat \\
\hline & Euphorbia polycarpa Bentham & smallseed sandmat \\
\hline & Euphorbia prostrata Aiton & prostrate sandmat \\
\hline & Euphorbia setiloba (Engelmann ex Torrey) Millspaugh & Yuma sandmat \\
\hline & Jatropha cardiophylla (Torrey) Muller Argoviensis & sangre de cristo \\
\hline & Jatropha cinerea (Ortega) Muller Argoviensis & Arizona nettlespurge \\
\hline & Jatropha cuneata Wiggins \& Rollins & physicnut \\
\hline & Sebastiana bilocularis S. Watson & arrow poision plant \\
\hline & Stillingia linearifolia S. Watson & queen's-root \\
\hline & Tragia nepetifolia Cavanilles & catnip noseburn \\
\hline \multirow[t]{22}{*}{ Fabaceae } & Acacia angustissima (Miller) Kuntze var. suffrutescens (Rose) Isely & prairie acacia \\
\hline & Acacia constricta Bentham & whitethorn acacia \\
\hline & Acacia greggii A. Gray & catclaw acacia \\
\hline & Astragalus didymocarpus Hooker \& Arnott var. dispermus (A. Gray) M.E. Jones & dwarf white milkvetch \\
\hline & Astragalus lentiginosus var. australis Barneby & freckled milkvetch \\
\hline & Astragalus lentiginosus var. yuccanus M.E. Jones & yucca milkvetch \\
\hline & Astragalus nuttallianus de Candolle var. imperfectus (Rydberg) Barneby & turkeypeas \\
\hline & Astragalus nuttallianus de Candolle var. austrinus (Small) R.C. Barneby & smallflowered milkvetch \\
\hline & Calliandra eriophylla Bentham var. eriophylla & fairyduster \\
\hline & Coursetia microphylla A. Grya & rosary babybonnets \\
\hline & Dalea mollis Bentham & hairy prairie clover \\
\hline & Dalea pogonathera A. Gray var. pogonathera & bearded prairie clover \\
\hline & Dalea pringlei A. Gray var. pringlei & Pringle's prairie clover \\
\hline & Desmodium procumbens (Miller) A.S. Hitchcock var. procumbens & western trailing ticktrefoil \\
\hline & Galactia wrightii A. Gray & Wright's milkpea \\
\hline & Lotus humistratus Greene & foothill deervetch \\
\hline & Lotus rigidus (Bentham) Greene & shrubby deervetch \\
\hline & Lotus salsuginosus Greene var. brevivexillus Ottley & coastal bird's-foot trefoil \\
\hline & Lotus strigosus (Nuttall) Greene var. tomentellus (Greene) Isely & strigose bird's-foot trefoil \\
\hline & Lupinus arizonicus (S. Watson) S. Watson & Arizona lupine \\
\hline & Lupinus concinnus Agardh & scarlet lupine \\
\hline & Lupinus sparsiflorus Bentham & Mojave lupine \\
\hline
\end{tabular}




\begin{tabular}{|c|c|c|}
\hline Family & Scientific name & Common name \\
\hline \multirow[t]{20}{*}{ Fabaceae } & Marina parryi (Torrey \& A. Gray ex A. Gray) Barneby & Parry's false prairie-clover \\
\hline & Medicago polymorpha Linnaeus & burclover \\
\hline & Melilotus indicus (Linnaeus) Allioni & annual yellow sweetclover \\
\hline & Mimosa distachya Cavanilles var. laxiflora (Bentham) Barneby & Arizona mimosa \\
\hline & Nissolia schottii (Torrey) A. Gray & Schott's yellowhood \\
\hline & Olneya tesota A. Gray & desert ironwood \\
\hline & Parkinsonia aculeata Linnaeus & Jerusalem thorn \\
\hline & Parkinsonia florida (Bentham ex A. Gray) S. Watson & blue paloverde \\
\hline & Parkinsonia microphylla Torrey & yellow paloverde \\
\hline & Phaseolus acutifolius A. Gray ssp. acutifolius & tepary bean \\
\hline & Phaseolus filiformis Bentham & slimjim bean \\
\hline & Prosopis glandulosa Torrey var. torreyana (L.D. Benson) M.C. Johnston & western honey mesquite \\
\hline & Prosopis pubescens Bentham & screwbean mesquite \\
\hline & Prosopis velutina Wooton & velvet mesquite \\
\hline & Psorothamnus spinosus (A. Gray) Barneby & smoketree \\
\hline & Rhynchosia senna Gillies ex Hooker \& Arnott var. texana (Torrey \& A. Gray) M.C. Johnston & Texas snoutbean \\
\hline & Senna covesii (A. Gray) Barneby \& Irwin & Coves' cassia \\
\hline & Tephrosia vicioides Schlechtendal & \\
\hline & Trifolium wormskioldii Lehmann var. arizonicum (Greene) Barneby & spinytooth clover \\
\hline & Vicia ludoviciana Nuttall var. Iudoviciana & Louisiana vetch \\
\hline Fagaceae & Quercus turbinella Greene & Sonoran scrub oak \\
\hline Fouqieriaceae & Fouquieria splendens Engelmann ssp. splendens & ocotillo \\
\hline \multirow[t]{2}{*}{ Gentianaceae } & Centaurium calycosum (Buckley) Fernald & Arizona centaury \\
\hline & Eustoma exaltatum (Linnaeus) G. don forma albiflorum Benke & catchfly prairie gentian \\
\hline \multirow[t]{3}{*}{ Geraniaceae } & Erodium cicutarium (Linnaeus) L'Heritier ex Aiton & redstem stork's bill \\
\hline & Erodium texanum A. Gray & Texas stork's bill \\
\hline & Geranium carolinianum Linnaeus & Carolina geranium \\
\hline \multirow[t]{11}{*}{ Hydrophyllaceae } & Eucrypta chrysanthemifolia (Bentham) Greene var. bipinnatifida (Torrey) Constance & spotted hideseed \\
\hline & Eucrypta micrantha (Torrey) A. Heller & dainty desert hideseed \\
\hline & Nama hispidum A. Gray & bristly nama \\
\hline & Phacelia affinis A. Gray & limestone phacelia \\
\hline & Phacelia ambigua M.E. Jones & purplestem phacelia \\
\hline & Phacelia caerulea Green & skyblue phacelia \\
\hline & Phacelia distans Bentham & distant phacelia \\
\hline & Phacelia neglecta M.E. Jones & alkali phacelia \\
\hline & Phacelia pedicellata A. Gray & pedicellate phacelia \\
\hline & Phacelia ramosissima Douglas ex Lehmann & branching phacelia \\
\hline & Pholistoma auritum (Lindley) Lilja var. arizonicum (M.E. Jones) Constance & Arizona fiestaflower \\
\hline Iridaceae & Sisyrinchium demissum Greene & stiff blue-eyed grass \\
\hline \multirow[t]{3}{*}{ Juncaceae } & Juncus articus Willdenow var. mexicanus (Willdenow ex Roemer \& Schultes) Balslev & Mexican rush \\
\hline & Juncus bufonius Linnaeus & toad rush \\
\hline & Juncus cooperi Engelmann & Cooper's rush \\
\hline \multirow[t]{2}{*}{ Krameriaceae } & Krameria erecta Willdenow ex Schultes & littleleaf ratany \\
\hline & Krameria grayi Rose \& Painter & white ratany \\
\hline \multirow[t]{8}{*}{ Lamiaceae } & Hedeoma nanum (Torrey) Briquet var. macrocalyx W.S. Stewart & dwarf false pennyroyal \\
\hline & Hyptis emoryi Torrey & desert lavender \\
\hline & Monardella arizonica Epling & Arizona monardella \\
\hline & Salazaria mexicana Torrey & Mexican bladdersage \\
\hline & Salvia columbariae Bentham & chia \\
\hline & Salvia pinguifolia (Fernald) Wooton \& Standley & rock sage \\
\hline & Teucrium cubense Jacquin ssp. depressum (Small) McClintock \& Epling & small coastal germander \\
\hline & 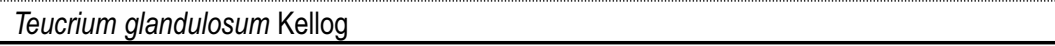 & common germander \\
\hline
\end{tabular}




\begin{tabular}{|c|c|c|}
\hline Family & Scientific name & Common name \\
\hline \multirow[t]{5}{*}{ Liliaceae } & Allium macropetalum Rydberg & largeflower onion \\
\hline & Calochortus kennedyi Porter & desert mariposa lily \\
\hline & Dichelostemma capitatum (Bentham) Wood ssp. pauciflorum (Torrey) Keator & bluedicks \\
\hline & Hesperocallis undulata A. Gray & desert lily \\
\hline & Zephyranthes longifolia Hemsley & copper zephyrlily \\
\hline Linaceae & Linum perenne Linnaeus ssp. lewisii (Pursh) Hulten & prairie flax \\
\hline \multirow[t]{7}{*}{ Loasaceae } & Eucnide rupestris (Baillon) H.J. Thomson \& W.R. Ernst & rock nettle \\
\hline & Mentzelia affinis Greene & yellowcomet \\
\hline & Mentzelia involucrata Watson & whitebract blazingstar \\
\hline & Mentzelia isolata H.S. Gentry & isolated blazingstar \\
\hline & Mentzelia multiflora (Nuttall) A. Gray & Adonis blazingstar \\
\hline & Petalonyx linearis Greene & narrowleaf sandpaper plant \\
\hline & Petalonyx thurberi Gray var. thurberi & Thurber's sandpaper plant \\
\hline Malpighiaceae & Janusia gracilis A. Gray & slender janusia \\
\hline \multirow[t]{20}{*}{ Malvaceae } & Abutilon abutiloides (Jacquin) Garcke ex Britton \& Wilson & shrubby indian mallow \\
\hline & Abutilon incanum (Link) Sweet & pelotazo \\
\hline & Abutilon malacum S. Watson & yellow Indian mallow \\
\hline & Abutilon palmeri A. Gray & Palmer's Indian mallow \\
\hline & Anoda pentaschista A. Gray & field anoda \\
\hline & Eremalche exilis (A. Gray) Greene & white mallow \\
\hline & Herrisantia crispa (Linnaeus) Brizicky & bladdermallow \\
\hline & Hibiscus biseptus S. Watson & Arizona rosemallow \\
\hline & Hibiscus coulteri Harvey & desert rosemallow \\
\hline & Hibiscus denudatus Bentham var. denudatus & paleface \\
\hline & Horsfordia alata (S. Watson) A. Gray & pink velvetmallow \\
\hline & Horsfordia newberryi (S. Watson) A. Gray & Newberry's velvetmallow \\
\hline & Malva parviflora Linnaeus & cheeseweed mallow \\
\hline & Malvastrum bicuspidatum (S. Watson) Rose ssp. bicuspidatum & shrubby false mallow \\
\hline & Rhynchosida physocalyx (A. Gray) Fryxell & buffpetal \\
\hline & Sida abutifolia Miller & spreading fanpetals \\
\hline & Sphaeralcea ambigua A. Gray ssp. ambigua & apricot globemallow \\
\hline & Sphaeralcea coulteri (S. Watson) A. Gray & Coulter's globemallow \\
\hline & Sphaeralcea emoryi Torrey & Emory's globemallow \\
\hline & Sphaeralcea laxa Wooton \& Standley & caliche globemallow \\
\hline \multirow[t]{2}{*}{ Martyniaceae } & Proboscidea altheaefolia (Bentham) Decaisne & desert unicorn-plant \\
\hline & Proboscidea parviflora (Wooton) Wooton \& Standley ssp. parviflora & doubleclaw \\
\hline Molluginaceae & Mollugo cerviana Seringe & threadstem carpetweed \\
\hline \multirow[t]{2}{*}{ Moraceae } & Ficus carica Linnaeus & edible fig \\
\hline & Morus microphylla Buckley & Texas mulberry \\
\hline Najadaceae & Najas marina Linnaeus & spiny naiad \\
\hline Nolinaceae & Nolina microcarpa S. Watson & sacahuista \\
\hline \multirow[t]{11}{*}{ Nyctaginaceae } & Allionia incarnata Linnaeus & trailing windmills \\
\hline & Boerhavia coccinea Miller & scarlet spiderling \\
\hline & Boerhavia erecta Linnaeus & erect spiderling \\
\hline & Boerhavia intermedia Linnaeus & fivewing spiderling \\
\hline & Boerhavia megaptera Standley & Tucson Mountain spiderling \\
\hline & Boerhavia pterocarpa S. Watson & Apache Pass spiderling \\
\hline & Boerhavia spicata Choisy & creeping spiderling \\
\hline & Boerhavia wrightii A. Gray & largebract spiderling \\
\hline & Commicarpus scandens (Linnaeus) Standley & climbing wartclub \\
\hline & Mirabilis laevis (Bentham) Curran var. villosa (Kellogg) Spellenberg & wishbone-bush \\
\hline & Mirabilis multiflora (Torrey) A. Gray & Colorado four o'clock \\
\hline
\end{tabular}




\begin{tabular}{|c|c|c|}
\hline Family & Scientific name & Common name \\
\hline \multirow[t]{2}{*}{ Oleaceae } & Foresteria phillyreoides (Bentham) Torrey & desert olive \\
\hline & Menodora scabra A. Gray & rough menodora \\
\hline \multirow[t]{11}{*}{ Onagraceae } & Camissonia boothii (Douglas) P.H. Raven ssp. condensatus (Munz) P.H. Raven & shredding suncup \\
\hline & Camissonia californica (Torrey \& A. Gray) P.H. Raven & California suncup \\
\hline & Camissonia chamaenerioides (A. Gray) P.H. Raven & longcapsule suncup \\
\hline & Camissonia claviformis (Torrey \& Fremont) P.H. Raven ssp. aurantiaca (Watson) Raven & browneyes \\
\hline & Camissonia claviformis (Torrey \& Fremont) P.H. Raven ssp. peeblesii (Munz) P.H. Raven & Peebles' browneyes \\
\hline & Camissonia claviformis (Torrey \& Fremont) P.H. Raven ssp. rubescens (P.H. Raven) P.H. Raven & browneyes \\
\hline & Camissonia claviformis (Torrey \& Fremont) P.H. Raven ssp. rubescens (P.H. Raven) P.H. Raven & browneyes \\
\hline & Epilobium canum (Greene) P.H. Raven ssp. latifolium (Hooker) P.H. Raven & hummingbird trumpet \\
\hline & Gaura parvifolia Hooker & velvetweed \\
\hline & Oenothera arizonica (Munz) W.L. Wagner & California evening-primrose \\
\hline & Oenothera primiveris A. Gray & desert evening-primrose \\
\hline \multirow[t]{2}{*}{ Orobanchaceae } & Orobanche cooperi (A. Gray) A. Heller & desert broomrape \\
\hline & Orobanche fasciculata Nuttall & clustered broomrape \\
\hline Oxalidaceae & Oxalis albicans Kunth & radishroot woodsorrel \\
\hline \multirow[t]{4}{*}{ Papaveraceae } & Argemone gracilenta Greene & Sonoran pricklypoppy \\
\hline & Argemone ochroleuca Sweet & \\
\hline & Eschscholtzia californica Chamisso ssp. mexicana (Greene) C. Clark & California poppy \\
\hline & Eschscholzia minutiflora S. Watson & pygmy poppy \\
\hline \multirow[t]{2}{*}{ Phytolaccacceae } & Plantago patagonica Jacquin & woolly plantain \\
\hline & Rivina humilis Linnaeus & rougeplant \\
\hline Plantaginaceae & Plantago ovata Forsskal & desert Indianwheat \\
\hline Plumbaginaceae & Plumbago zeylanica Linnaeus & wild leadwort \\
\hline \multirow[t]{27}{*}{ Poaceae } & Aristida adscensionis Linnaeus & sixweeks threeawn \\
\hline & Aristida californica Thurberi var. glabrata Vasey & Santa Rita threeawn \\
\hline & Aristida parishii Hitchcock & Parish's threeawn \\
\hline & Aristida purpurea Nuttall var. nealleyi (Vasey) Allred & blue threeawn \\
\hline & Aristida purpurea Nuttall var. purpurea & purple threeawn \\
\hline & Aristida ternipes Cavanilles var. gentilis (Henrard) Allred & spidergrass \\
\hline & Aristida ternipes Cavanilles var. ternipes & spidergrass \\
\hline & Avena fatua Linnaeus & wild oat \\
\hline & Bothriochloa barbinodis (Lagasca) Herter & cane bluestem \\
\hline & Bouteloua aristidoides (Kunth) Grisebach & needle grama \\
\hline & Bouteloua barbata (Lagasca) Herter & sixweeks grama \\
\hline & Bouteloua curtipendula (Michaux) Torrey & sideoats grama \\
\hline & Bouteloua repens (Humboldt, Bonpland \& Kunth) Scribner \& Merrill & slender grama \\
\hline & Bouteloua rothrockii Vasey & Rothrock's grama \\
\hline & Bouteloua trifida Thurber ex S. Watson & red grama \\
\hline & Brachiaria arizonica (Scribner \& Merrill) S.T. Blake & Arizona signalgrass \\
\hline & Bromus carinatus Hooker \& Arnott & California brome \\
\hline & Bromus rubens Linnaeus & red brome \\
\hline & Cenchrus echinatus Linnaeus & southern sandbur \\
\hline & Chloris virgata Swartz & feather fingergrass \\
\hline & Cottea pappophoroides Kunth & cotta grass \\
\hline & Cynodon dactylon (Linnaeus) Persoon var. dactylon & Bermudagrass \\
\hline & Dactyloctenium aegyptium (Linnaeus) Willdenow & Egyptian grass \\
\hline & Dasyochloa pulchella (Kunth) Willdenow ex Rydberg & low woollygrass \\
\hline & Digitaria californica (Bentham) Henrard & Arizona cottontop \\
\hline & Distichlis spicata (Linnaeus) Greene & inland saltgrass \\
\hline & Echinochloa colonum (Linnaeus) Link & jungle rice \\
\hline
\end{tabular}




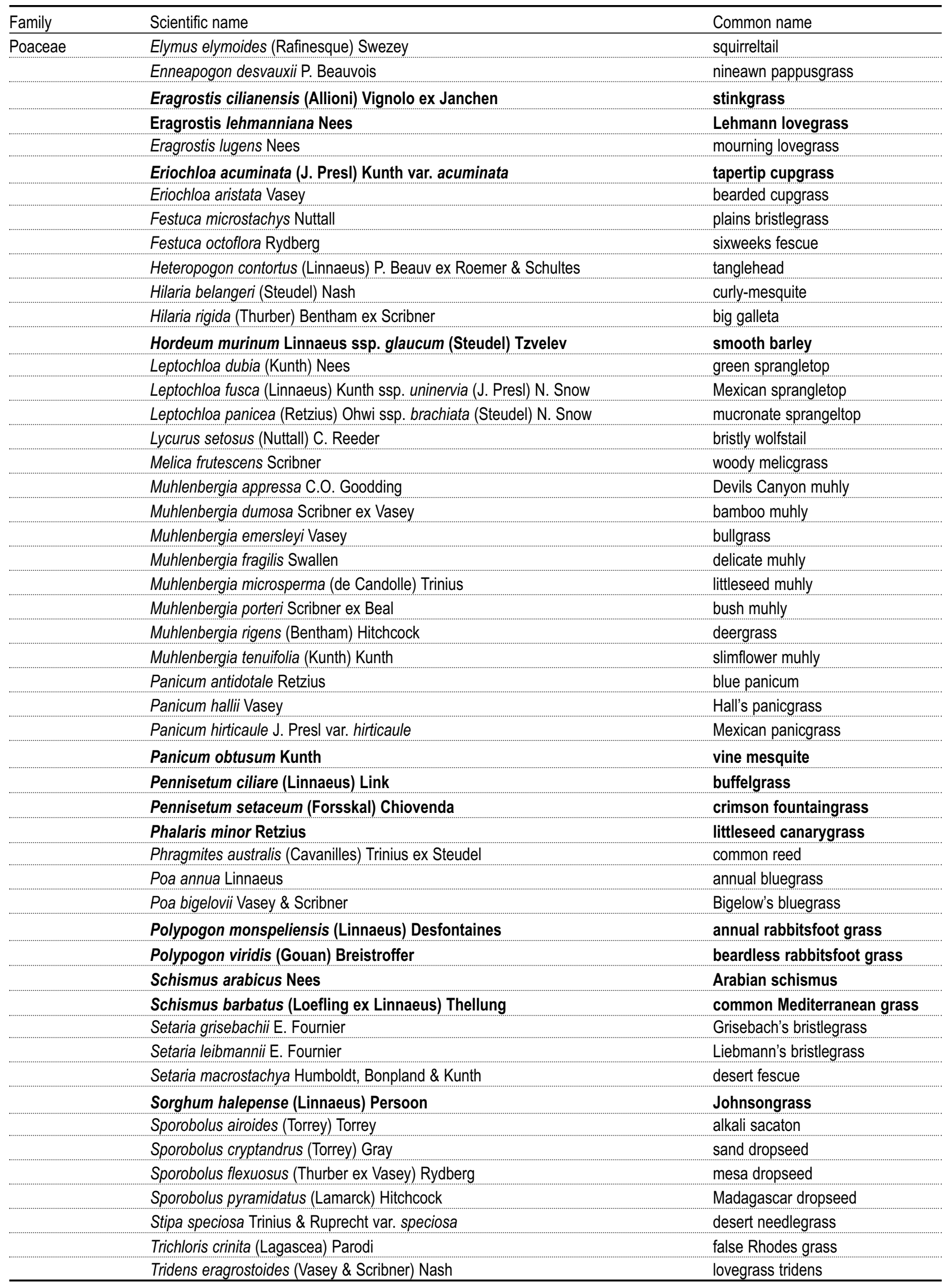




\begin{tabular}{|c|c|c|}
\hline Family & Scientific name & Common name \\
\hline \multirow[t]{2}{*}{ Poaceae } & Tridens muticus (Torrey) A. Gray var. muticus & slim tridens \\
\hline & Triticum aestivum $\mathrm{L}$. & common wheat \\
\hline \multirow[t]{10}{*}{ Polemoniaceae } & Eriastrum diffusum (A. Gray) Mason & miniature woollystar \\
\hline & Eriastrum eremicum (Jepson) H. Mason & desert woollystar \\
\hline & Gilia flavocincta A Nelson ssp. australis (A.D. \& V.E. Grant) A.G. Day \& V.E. Grant & lesser yellowthroat gilia \\
\hline & Gilia stellata Heller & star gilia \\
\hline & Ipomopsis multiflora (Nuttall) V. Grant & manyflowered ipomopsis \\
\hline & Langloisia setosissima (Torrey \& A. Gray) Greene & Great Basin langloisia \\
\hline & Linanthus aureus (Nuttall) Greene & golden linanthus \\
\hline & Linanthus bigelovii (A. Gray) Greene & Bigelow's linanthus \\
\hline & Linanthus demissus (A. Gray) Greene & desertsnow \\
\hline & Phlox tenuifolia E. Nelson & Santa Catalina Mountain phlox \\
\hline \multirow[t]{14}{*}{ Polygalaceae } & Polygala macradenia A. Gray & glandleaf milkwort \\
\hline & Chorizanthe brevicornu Torrey & brittle spineflower \\
\hline & Chorizanthe currugata (Torrey) Torrey \& A. Gray & wrinkled spineflower \\
\hline & Chorizanthe rigida (Torrey) Torrey \& A. Gray & devil's spineflower \\
\hline & Eriogonum abertianum Torrey & Abert's buckwheat \\
\hline & Eriogonum deflexum Torrey & flatcrown buckwheat \\
\hline & Eriogonum fasciculatum Bentham var. polifolium (Bentham) Torrey \& A. Gray & Eastern Mojave buckwheat \\
\hline & Eriogonum inflatum Torrey \& Fremont & desert trumpet \\
\hline & Eriogonum thomasii Torrey & Thomas' buckwheat \\
\hline & Eriogonum trichopes Torrey & little deserttrumpet \\
\hline & Eriogonum wrightii Torrey ex Bentham var. nodosum (Small) Reveal & bastardsage \\
\hline & Polygonum argyrocoleon Steudel ex Kunze & silversheath knotweed \\
\hline & Pterostegia drymarioides Fischer \& Meyer & woodland pterostegia \\
\hline & Rumex hymenosepala Torrey & canaigre dock \\
\hline \multirow[t]{9}{*}{ Portulacaceae } & Calandrinia ciliata (Ruiz \& Pavon) de Candolle & fringed redmaids \\
\hline & Cistanthe monandra (Nutall) Hershkovitz & common pussypaws \\
\hline & $\begin{array}{l}\text { Claytonia perfoliata (Donn ex Willdenow) ssp. mexicana (Rydberg) John M Miller } \\
\text { \& K.L. Chambers }\end{array}$ & miner's lettuce \\
\hline & Phemeranthus aurantiacus (Englemann) Kiger & orange fameflower \\
\hline & Portulaca halimoides Linnaeus & silkcotton purslane \\
\hline & Portulaca oleraceae Linnaeus & little hogweed \\
\hline & Portulaca suffrutescens Engelmann & shrubby purslane \\
\hline & Portulaca umbraticola Kunth ssp. lanceolata J.F. Matthews \& Ketron & wingpod purslane \\
\hline & Talinum paniculatum (Jacquin) Gaertner & jewels of Opar \\
\hline Potamogetonaceae & Stuckenia pectinatus (Linnaeus) Borner & sago pondweed \\
\hline \multirow[t]{2}{*}{ Primulaceae } & Anagallis arvensis $\mathrm{L}$. & scarlet pimpernel \\
\hline & Androsace occidentalis Pursh & western rockjasmine \\
\hline \multirow[t]{13}{*}{ Pteridaceae } & Argyrochosma limitanae (Maxon) Windham ssp. limitanae & southwestern false cloakfern \\
\hline & Astrolepis cochisensis (Goodding) D.M. Bentham \& Windham ssp. cochisensis & Cochise scaly cloakfern \\
\hline & Astrolepis sinuata (Lagasca ex Swartz) D.M. Benham \& Windham ssp. sinuata & wavy scaly cloakfern \\
\hline & Bommeria hispida (Kuhn) L. Underwood & copper fern \\
\hline & Cheilanthes lindheimeri Hooker & fairyswords \\
\hline & Cheilanthes parryi (D.C. Eaton) Domin & Parry's lipfern \\
\hline & Cheilanthes villosa Davenport ex Maxon & villous lipfern \\
\hline & Cheilanthes wrightii Hooker & Wright's lipfern \\
\hline & Cheilanthes yavapensis T. Reeves ex Windham & graceful lipfern \\
\hline & Notholaena californica D.C. Eaton ssp. californica & California cloak fern \\
\hline & Notholaena standleyi Maxon & star cloak fern \\
\hline & Pellaea truncata Goodding & spiny cliffbrake \\
\hline & Pentagramma triangularis (Kaulfuss) Yatskievych, Windham \& Wollenweber & goldback fern \\
\hline
\end{tabular}




\begin{tabular}{|c|c|c|}
\hline Family & Scientific name & Common name \\
\hline Punicaceae & Punica granatum Linnaeus & pomegranate \\
\hline \multirow[t]{5}{*}{ Ranunculaceae } & Anemone tuberosa Rydberg & tuber anemone \\
\hline & Clematis drummondii Torrey \& A. Gray & Drummond's clematis \\
\hline & Delphinium scaposum Greene & tall mountain larkspur \\
\hline & Myosurus cupulatus S. Watson & Arizona mousetail \\
\hline & Myosurus minimus Linnaeus & tiny mousetail \\
\hline Resedaceae & Oligomeris linifolia (Vahl) Macbride & lineleaf whitepuff \\
\hline \multirow[t]{4}{*}{ Rhamnaceae } & Ziziphus obtusifolia (Hooker ex Torrey \& Gray) Gray & lotebush \\
\hline & Condalia globosa I.M. Johnston var. pubescens I.M. Johnston & bitter snakewood \\
\hline & Rhamnus betulifolia Greene & beechleaf frangula \\
\hline & Rhamnus ilicifolia Kellogg & hollyleaf redberry \\
\hline Rosaceae & Vauquelinia californica (Torrey) Sargent ssp. sonorensis W.J. Hess \& Henrickson & Sonora rosewood \\
\hline \multirow[t]{3}{*}{ Rubiaceae } & Galium aparine $\mathrm{L}$. & stickywilly \\
\hline & Galium microphyllum A. Gray & bracted bedstraw \\
\hline & Galium stellatum Kellog var. eremicum Hilend \& Howell & starry bedstraw \\
\hline Ruppiaceae & Ruppia cirrhosa (Petagna) Grande & spiral ditchgrass \\
\hline Rutaceae & Ptelea trifoliata Linnaeus & common hoptree \\
\hline \multirow[t]{2}{*}{ Salicaceae } & Populus fremontii S. Watson ssp. fremontii & Fremont cottonwood \\
\hline & Salix gooddingii C.R. Ball & Goodding's willow \\
\hline \multirow[t]{2}{*}{ Sapindaceae } & Dodonaea viscosa Jacquin var. angustifolia (Linnaeus f.) Bentham & Florida hopbush \\
\hline & Sapindus marginatus Willdenow & wingleaf soapberry \\
\hline Saururaceae & Anemopsis californica (Nuttall) Hooker \& Arnott & yerba mansa \\
\hline Saxifragaceae & Ribes quercetorum Greene & rock gooseberry \\
\hline \multirow[t]{15}{*}{ Scrophulariaceae } & Antirrhinum cyathiferum Bentham & dog's-mouth \\
\hline & Antirrhinum filipes A. Gray & Filipes snapdragon \\
\hline & Antirrhinum nuttalianum Bentham ssp. subsessile (A. Gray) D. Thompson & Texas toadflax \\
\hline & Antirrhinum watsonii Vasey \& Rose & Watson's snapdragon \\
\hline & Castilleja exserta (A. Heller) Chuang \& Heckard ssp. exserta & exserted Indian paintbrush \\
\hline & Castilleja lanata Gray & Sierra woolly Indian paintbrush \\
\hline & Keckiella antirrhinoides (Bentham) Straw ssp. microphylla (A. Gray) Straw & snapdragon penstemon \\
\hline & Linaria canadensis (Linnaeus) Dumont de Courset var. texana (Scheele) Pennell & lesser snapdragon \\
\hline & Maurandya antirrhiniflora Humboldt \& Bonpland ex Willdenow ssp. antirrhiniflora & roving sailor \\
\hline & Mimulus guttatus de Candolle & seep monkeyflower \\
\hline & Mimulus rubellus A. Gray & little redstem monkeyflower \\
\hline & Penstemon parryi A. Gray & Parry's beardtongue \\
\hline & Penstemon pseudospectabilis M.E. Jones var. pseudospectabilis & desert beardtongue \\
\hline & Stemodia durantifolia (Linnaeus) Swartz & whitewoolly twintip \\
\hline & Veronica peregrina Linnaeus var. xalapensis (Kunth) Pennell & hairy purslane speedwell \\
\hline \multirow[t]{2}{*}{ Selaginellaceae } & Selaginella arizonica Maxon & Arizona spikemoss \\
\hline & Selaginella eremophila Maxon & desert spikemoss \\
\hline Simaroubaceae & Castela emoryi (A. Gray) Moran \& Felger & crucifixion thorn \\
\hline Simmondsiaceae & Simmondsia chinensis (Link) C.K. Schneider & jojoba \\
\hline \multirow[t]{10}{*}{ Solanaceae } & Calibrachoa parviflora (Jussieu) D'Arcy & seaside petunia \\
\hline & Capsicum annuum Linnaeus var. aviculare (Dierbach) D'Arcy \& Eschbaugh & cayenne pepper \\
\hline & Datura discolor Bernhardi & desert thorn-apple \\
\hline & Lycium andersonii A. Gray var. andersonii & water jacket \\
\hline & Lycium berlandieri Dunal var. Iongistylum C.L. Hitchcock & Berlandier's wolfberry \\
\hline & Lycium brevipes Benth & Baja desert-thorn \\
\hline & Lycium californicum Nuttall ex A. Gray var. californicum A. Gray & California desert-thorn \\
\hline & Lycium exsertum A. Gray & Arizona desert-thorn \\
\hline & Lycium fremontii A. Gray var. fremontii & Fremont's desert-thorn \\
\hline & Lycium macrodon A. Gray var. macrodon & desert wolfberry \\
\hline
\end{tabular}




\begin{tabular}{|c|c|c|}
\hline Family & Scientific name & Common name \\
\hline \multirow[t]{10}{*}{ Solanaceae } & Lycium parishii A. Gray var. parishii & Parish's desert-thorn \\
\hline & Nicotiana clevelandii A. Gray & Cleveland's tobacco \\
\hline & Nicotiana obtusifolia M. Martens \& Galeotti & desert tobacco \\
\hline & Physalis acutifolia (Miers) Sandwith & sharpleaf groundcherry \\
\hline & Physalis crassifolia Bentham var. versicolor (Rydberg) Waterfall & yellow nightshade groundcherry \\
\hline & Physalis lobata Torrey & Chinese lantern \\
\hline & Solanum americanum Miller & American black nightshade \\
\hline & Solanum douglasii Dunal & greenspot nightshade \\
\hline & Solanum hindsianum Bentham & Hinds' nightshade \\
\hline & Solanum xanti A. Gray & chaparral nightshade \\
\hline \multirow[t]{2}{*}{ Sterculiaceae } & Ayenia filiformis S. Watson & TransPecos ayenia \\
\hline & Ayenia microphylla A. Gray & dense ayenia \\
\hline \multirow[t]{2}{*}{ Tamaricaceae } & Tamarix aphylla (Linnaeus) H. Karston & Athel tamarisk \\
\hline & Tamarix ramosissima Ledebour & saltcedar \\
\hline Typhaceae & Typha domingensis Persoon & southern cattail \\
\hline \multirow[t]{2}{*}{ Ulmaceae } & Celtis pallida Torrey & spiny hackberry \\
\hline & Celtis reticulata Torrey & netleaf hackberry \\
\hline Urticaceae & Parietaria hespera Hinton var. hespera & rillita pellitory \\
\hline \multirow[t]{7}{*}{ Verbenaceae } & Aloysia wrightii A. Heller ex Abrams & Wright's beebrush \\
\hline & Glandularia bipinnatifida (Nuttall) Nuttall var. bipinnatifida & Dakota mock vervain \\
\hline & Glandularia gooddingii (Briquet) Solbrig & southwestern mock vervain \\
\hline & Lantana camara Linnaeus & lantana \\
\hline & Tetraclea coutleri Gray & Coulter's wrinklefruit \\
\hline & Verbena neomexicana (A. Gray) Small & hillside vervain \\
\hline & Verbena officinalis Linnaeus ssp. halei (Small) S.C. Barber & Texas vervain \\
\hline Viscaceae & Phoradendron californicum Nuttall & mesquite mistletoe \\
\hline Zanichelliaceae & Zanichellia palustris Linnaeus & horned pondweed \\
\hline \multirow[t]{5}{*}{ Zygophyllaceae } & Fagonia californica Bentham ssp. longipes (Standley) Felger \& C.H. Lowe & California fagonbush \\
\hline & Kallstroemia californica (S. Watson) Vail & California caltrop \\
\hline & Kallstroemia grandiflora Torrey ex A. Gray & Arizona poppy \\
\hline & Larrea divaricata Cavanilles ssp. tridentata (Sesse \& Mocino ex DeCandolle) & \\
\hline & Felger \& Lowe & creosote bush \\
\hline
\end{tabular}


Appendix B. Amphibian and reptile species recorded at Organ Pipe Cactus NM based on list by Rosen and Lowe (1996) and voucher specimens (Appendix F).

\begin{tabular}{|c|c|c|c|c|c|c|c|}
\hline Order & Family & Scientific name & Common name & $\mathrm{ESA}^{\mathrm{a}}$ & BLM $^{b}$ & USFS $^{\mathrm{c}}$ & $A Z G \& F^{d}$ \\
\hline \multirow[t]{5}{*}{ Anura } & Pelobatidae & Scaphiopus couchii & Couch's spadefoot & & & & \\
\hline & Bufonidae & Bufo alvarius & Sonoran desert toad & & & & \\
\hline & & Bufo punctatus & red-spotted toad & & & & \\
\hline & & Bufo cognatus & Great Plains toad & & & & \\
\hline & & Bufo retiformis & Sonoran green toad & & & & \\
\hline \multirow[t]{2}{*}{ Testudines } & Kinosternidae & Kinosternon sonoriense longifemorale & Sonoran mud turtle & C & & $x$ & \\
\hline & Testudinidae & Gopherus agassizii & desert tortoise & SC & & & $X$ \\
\hline \multirow[t]{36}{*}{ Squamata } & Eublepharidae & Coleonyx variegates & western banded gecko & & & & \\
\hline & Iguanidae & Dipsosaurus dorsalis & desert iguana & & & & \\
\hline & & Sauromalus obesus & common chuckwalla & SC & $x$ & & \\
\hline & Crotaphytidae & Crotaphytus collaris & eastern collared lizard & & & & \\
\hline & & Gambelia wislizenii & long-nosed leopard lizard & & & & \\
\hline & Phrynosomatidae & Callisaurus draconoides & zebra-tailed lizard & & & & \\
\hline & & Sceloporus magister & desert spiny lizard & & & & \\
\hline & & Sceloporus clarkia & Clark's spiny lizard & & & & \\
\hline & & Uta stansburiana & common side-blotched lizard & & & & \\
\hline & & Urosaurus graciosus & long-tailed brush lizard & & & & \\
\hline & & Urosaurus ornatus & ornate tree lizard & & & & \\
\hline & & Phrynosoma platyrhinos & desert horned lizard & & & & \\
\hline & & Phrynosoma solare & regal horned lizard & & & & \\
\hline & Teiidae & Cnemidophorus burti & canyon spotted whiptail & SC & $X$ & $x$ & \\
\hline & & Cnemidophorus tigris & western whiptail (tiger whiptail) & & & & \\
\hline & Helodermatidae & Heloderma suspectum & Gila monster & & & & \\
\hline & Leptotyphlopidae & Leptotyphlops humilis & western blind snake & & & & \\
\hline & Boidae & Charina trivirgata trivirgata & rosy boa & SC & $x$ & & \\
\hline & Colubridae & Phyllorhynchus decurtatus & spotted leaf-nosed snake & & & & \\
\hline & & Phyllorhynchus browni & saddled leaf-nosed snake & & & & \\
\hline & & Masticophis flagellum & coachwhip & & & & \\
\hline & & Masticophis bilineatus & Sonoran whipsnake & & & & \\
\hline & & Salvadora hexalepis & western patch-nosed snake & & & & \\
\hline & & Pituophis catenifer & gopher snake & & & & \\
\hline & & Arizona elegans & glossy snake & & & & \\
\hline & & Lampropeltis getula & common kingsnake & & & & \\
\hline & & Rhinocheilus lecontei & long-nosed snake & & & & \\
\hline & & Thamnophis cyrtopsis & black-necked garter snake & & & & \\
\hline & & Sonora semiannulata & western ground snake & & & & \\
\hline & & Chionactis occipitalus & western shovel-nosed snake & & & & \\
\hline & & Chionactis palarostris & Sonoran shovel-nosed snake & & & $X$ & \\
\hline & & Chilomeniscus cinctus & variable sandsnake & & & & \\
\hline & & Tantilla hobartsmithi & southwestern black-headed snake & & & & \\
\hline & & Trimorphodon biscutatus & western lyre snake & & & & \\
\hline & & Hypsiglena torquata & night snake & & & & \\
\hline & Elapidae & Micruroides euryxanthus & Sonoran coral snake & & & & \\
\hline
\end{tabular}




\begin{tabular}{|c|c|c|c|c|c|c|c|}
\hline Order & Family & Scientific name & Common name & $\mathrm{ESA}^{\mathrm{a}}$ & $\mathrm{BLM}^{\mathrm{b}}$ & USFS $^{c}$ & $A Z G \& F^{\circ}$ \\
\hline & \multirow[t]{6}{*}{ Viperidae } & Crotalus atrox & western diamond-backed rattlesnake & & & & \\
\hline & & Crotalus cerastes & sidewinder & & & & \\
\hline & & Crotalus mitchellii & speckled rattlesnake & & & & \\
\hline & & Crotalus molossus & black-tailed rattlesnake & & & & \\
\hline & & Crotalus tigris & tiger rattlesnake & & & & \\
\hline & & Crotalus scutulatus & Mojave rattlesnake & & & & \\
\hline
\end{tabular}

a "SC" = "Species of Concern"; "C" = "Candidate Species" under the Endangered Species Act (HDMS 2004).

b "Sensitive" species; USDA Forest Service (HDMS 2004).

"Sensitive" species; Bureau of Land Management (HDMS 2004).

d "Wildlife Species of Concern"; Arizona Game and Fish Department (HDMS 2004). 
Appendix C. Bird species recorded at Organ Pipe Cactus NM based on lists by Groschupf et al. (1988; Gros), Tibbitts and Dickson (2005; T\&D), and Benson et al. (2001; BE). Species in bold-faced type are non-native. Underlined species are neotropical migrants (Rappole 1995).

\begin{tabular}{|c|c|c|c|c|c|c|c|c|c|c|c|}
\hline \multicolumn{12}{|l|}{ Order } \\
\hline Family & Scientific name & Common name & Gros & T\&D & $\mathrm{BE}$ & $E A^{a}$ & BLM $^{b}$ & USFS $^{c}$ & $A Z^{d}$ & $\mathrm{APF}^{\mathrm{e}}$ & USFWS $^{\dagger}$ \\
\hline \multicolumn{12}{|l|}{ Anseriformes } \\
\hline \multirow[t]{21}{*}{ Anatidae } & Chen caerulescens & snow goose & & $x$ & & & & & & & \\
\hline & Branta canadensis & Canada goose & $x$ & & & & & & & & \\
\hline & Aix sponsa & wood duck & $x$ & & & & & & & & \\
\hline & Anas strepera & gadwall & $X$ & & & & & & & & \\
\hline & Anas americana & American wigeon & $X$ & & & & & & & & \\
\hline & Anas platyrhynchos & mallard & $x$ & & & & & & & & \\
\hline & Anas discors & blue-winged teal & $X$ & & & & & & & & \\
\hline & Anas cyanoptera & cinnamon teal & $X$ & & & & & & & & \\
\hline & Anas clypeata & northern shoveler & $X$ & & & & & & & & \\
\hline & Anas acuta & northern pintail & $X$ & & & & & & & & \\
\hline & Anas crecca & green-winged teal & $X$ & & & & & & & & \\
\hline & Aythya valisineria & canvasback & $x$ & & & & & & & & \\
\hline & Aythya americana & redhead & $x$ & & & & & & & & \\
\hline & Aythya collaris & ring-necked duck & $X$ & & & & & & & & \\
\hline & Aythya affinis & lesser scaup & $x$ & & & & & & & & \\
\hline & Bucephala albeola & bufflehead & $X$ & & & & & & & & \\
\hline & Bucephala clangula & common goldeneye & $x$ & & & & & & & & \\
\hline & Lophodytes cucullatus & hooded merganser & $x$ & & & & & & & & \\
\hline & Mergus merganser & common merganser & $X$ & & & & & & & & \\
\hline & Mergus serrator & red-breasted merganser & $x$ & & & & & & & & \\
\hline & Oxyura jamaicensis & ruddy duck & $x$ & & & & & & & & \\
\hline \multicolumn{12}{|l|}{ Galliformes } \\
\hline \multicolumn{2}{|c|}{$\begin{array}{l}\text { Odontophoridae } \\
\text { Callipepla gambelii }\end{array}$} & Gambel's quail & $X$ & & & & & & & & \\
\hline \multicolumn{12}{|l|}{ Gaviiformes } \\
\hline Gaviidae & Gavia immer & common loon & $x$ & & & & & & & & \\
\hline \multicolumn{12}{|c|}{ Podicipediformes } \\
\hline \multirow[t]{4}{*}{ Podicipedidae } & Tachybaptus dominicus & least grebe & $x$ & & & & & & & & \\
\hline & Podilymbus podiceps & pied-billed grebe & $x$ & & & & & & & & \\
\hline & Podiceps nigricollis & eared grebe & $X$ & & & & & & & & \\
\hline & Aechmophorus occidentalis & western grebe & $x$ & & & & & & & & \\
\hline \multicolumn{12}{|c|}{ Pelecaniformes } \\
\hline \multirow[t]{2}{*}{ Pelecanidae } & Pelecanus erythrorhynchos & American white pelican & $x$ & & & & & & & & \\
\hline & Pelecanus occidentalis & brown pelican & $X$ & & & LE & & $x$ & & & \\
\hline \multicolumn{12}{|c|}{ Phalacrocoracidae } \\
\hline \multicolumn{12}{|l|}{ Ciconiiformes } \\
\hline \multirow[t]{7}{*}{ Ardeidae } & Ixobrychus exilis & least bittern & $X$ & & & & & & $X$ & & \\
\hline & Ardea herodias & great blue heron & $X$ & & & & & & & & \\
\hline & Ardea alba & great egret & $x$ & & & & & & $x$ & & \\
\hline & Egretta thula & snowy egret & $x$ & & & & & & $x$ & & \\
\hline & Bubulcus ibis & cattle egret & $x$ & & & & & & & & \\
\hline & Butorides virescens & green heron & $x$ & & & & & & & & \\
\hline & Nycticorax nycticorax & black-crowned night-heron & $x$ & & & & & & & & \\
\hline \multicolumn{12}{|c|}{ Threskiornithidae } \\
\hline & Plegadis chihi & white-faced lbis & $X$ & & & SC & & $x$ & & & \\
\hline & Platalea ajaja & roseate spoonbill & $X$ & & & & & & & & \\
\hline
\end{tabular}




\begin{tabular}{|c|c|c|c|c|c|c|c|c|c|c|c|}
\hline \\
\hline \multicolumn{12}{|l|}{ Ciconiiformes } \\
\hline Ciconiidae & Mycteria americana & wood stork & $\mathrm{x}$ & & & LE & & & & & \\
\hline \multirow[t]{2}{*}{ Cathartidae } & Coragyps atratus & black vulture & $\mathrm{X}$ & & & & & & & & \\
\hline & Cathartes aura & turkey vulture & $x$ & & & & & & & & \\
\hline \multicolumn{12}{|l|}{ Falconiformes } \\
\hline \multirow[t]{13}{*}{ Accipitridae } & Pandion haliaetus & osprey $\quad$ - & $x$ & & & & & & $\mathrm{x}$ & & \\
\hline & Elanus leucurus & white-tailed kite & $x$ & & & & & & & & \\
\hline & Circus cyaneus & northern harrier & $x$ & & & & & & & & \\
\hline & Accipiter striatus & sharp-shinned hawk & $x$ & & & & & $\mathrm{x}$ & & & \\
\hline & Accipiter cooperii & Cooper's hawk & $x$ & & & & & & & & \\
\hline & Buteogallus anthracinus & common black-hawk & $x$ & & & & & $x$ & $\mathrm{X}$ & $\mathrm{x}$ & \\
\hline & Parabuteo unicinctus & Harris's hawk & $x$ & & & & & & & & \\
\hline & Buteo swainsoni & Swainson's hawk & $x$ & & & & & & & & \\
\hline & Buteo albicaudatus & white-tailed hawk & $x$ & & & & & & & & \\
\hline & Buteo albonotatus & zone-tailed hawk & $x$ & & & & & & & & \\
\hline & Buteo jamaicensis & red-tailed hawk & $\mathrm{x}$ & & & & & & & & \\
\hline & Buteo regalis & ferruginous hawk & $\mathrm{x}$ & & & SC & & & $\mathrm{x}$ & & \\
\hline & Aquila chrysaetos & golden eagle & $x$ & & & & & & & & \\
\hline \multirow[t]{5}{*}{ Falconidae } & Caracara cheriway & crested caracara & $x$ & & & & & & $\mathrm{x}$ & & \\
\hline & Falco sparverius & American kestrel & $x$ & & & & & & & & \\
\hline & Falco columbarius & merlin & $x$ & & & & & & & & \\
\hline & Falco peregrinus & peregrine falcon & $x$ & & & SC & & & $\mathrm{X}$ & & $x$ \\
\hline & Falco mexicanus & prairie falcon & $x$ & & & & & & & & \\
\hline \multicolumn{12}{|l|}{ Gruiformes } \\
\hline \multirow[t]{5}{*}{ Rallidae } & Laterallus jamaicensis & black rail & $x$ & & & SC & & & $x$ & & $x$ \\
\hline & Rallus limicola limicola & Virginia rail & $x$ & & & & & & & & \\
\hline & Porzana carolina & sora & $x$ & & & & & & & & \\
\hline & Gallinula chloropus & common moorhen & $x$ & & & & & & & & \\
\hline & Fulica americana & American coot & $x$ & & & & & & & & \\
\hline Gruidae & Grus canadensis & sandhill crane & $x$ & & & & & & & & \\
\hline \multicolumn{12}{|c|}{ Charadriiformes } \\
\hline \multirow[t]{2}{*}{ Charadriidae } & Charadrius semipalmatus & semipalmated plover & $x$ & & & & & & & & \\
\hline & Charadrius vociferus & killdeer & $x$ & & & & & & & & \\
\hline \multicolumn{12}{|c|}{ Recurvirostridae } \\
\hline & $\begin{array}{l}\text { Himantopus mexicanus } \\
\text { Recurvirostra americana }\end{array}$ & $\begin{array}{l}\text { black-necked stilt } \\
\text { American avocet }\end{array}$ & $x$ & & & & & & & & \\
\hline \multirow[t]{15}{*}{ Scolopacidae } & Tringa melanoleuca & greater yellowlegs & $\mathrm{x}$ & & & & & & & & \\
\hline & Tringa flavipes & lesser yellowlegs & $x$ & & & & & & & & \\
\hline & Tringa solitaria & solitary sandpiper & $x$ & & & & & & & & \\
\hline & Catoptrophorus semipalmatus & willet & $x$ & & & & & & & & \\
\hline & Actitis macularia & spotted sandpiper & $x$ & & & & & & & & \\
\hline & Numenius americanus & long-billed curlew & $x$ & & & & & & & & \\
\hline & Calidris mauri & western sandpiper & $\mathrm{x}$ & & & & & & & & \\
\hline & Calidris minutilla & least sandpiper & $x$ & & & & & & & & \\
\hline & Calidris bairdii & Baird's sandpiper & $\mathrm{x}$ & & & & & & & & \\
\hline & Calidris himantopus & stilt sandpiper & $x$ & & & & & & & & \\
\hline & Limnodromus scolopaceus & long-billed dowitcher & $x$ & & & & & & & & \\
\hline & Gallinago gallinago & common snipe & $x$ & & & & & & & & \\
\hline & Phalaropus tricolor & Wilson's phalarope & $\mathrm{x}$ & & & & & & & & \\
\hline & $\overline{\text { Phalaropus lobatus }}$ & red-necked phalarope & $x$ & & & & & & & & \\
\hline & Phalaropus fulicarius & red phalarope & $x$ & & & & & & & & \\
\hline
\end{tabular}




\begin{tabular}{|c|c|c|c|c|c|c|c|c|c|c|c|}
\hline $\begin{array}{l}\text { Order } \\
\text { Family }\end{array}$ & Scientific name & Common name & Gros & $T \& D$ & $\mathrm{BE}$ & $F S A^{a}$ & $B \perp M^{b}$ & USFS & $A Z^{d}$ & $A P F^{e}$ & USFW' \\
\hline Charadriiforr & & & & & & & & & & & \\
\hline Laridae & Larus philadelphia & Bonaparte's gull & $\mathrm{X}$ & & & & & & & & \\
\hline & Larus heermanni & Heermann's gull & $\mathrm{x}$ & & & & & & & & \\
\hline & Larus delawarensis & ring-billed gull & $\mathrm{X}$ & & & & & & & & \\
\hline & Larus californicus & California gull & $\mathrm{x}$ & & & & & & & & \\
\hline & Larus argentatus & herring gull & $x$ & & & & & & & & \\
\hline & Sterna hirundo & common tern & $\mathrm{X}$ & & & & & & & & \\
\hline & Sterna forsteri & Forster's tern & $\mathrm{x}$ & & & & & & & & \\
\hline & Sterna antillarum & least tern & $\mathrm{x}$ & & & & & & & & \\
\hline & Chlidonias niger & black tern & $\mathrm{X}$ & & & & & & & & \\
\hline Columbiform & & & & & & & & & & & \\
\hline Columbidae & Columba livia & rock pigeon & $\mathrm{x}$ & & & & & & & & \\
\hline & Patagioenas fasciata & band-tailed pigeon & $\mathrm{X}$ & & & & & & & & \\
\hline & Zenaida asiatica & white-winged dove & $X$ & & & & & & & & \\
\hline & Zenaida macroura & mourning dove & $\mathrm{x}$ & & & & & & & & \\
\hline & Columbina inca & Inca dove & $\mathrm{X}$ & & & & & & & & \\
\hline & Columbina passerina & common ground-dove & $x$ & & $x$ & & & & & & \\
\hline Cuculiforme: & & & & & & & & & & & \\
\hline Cuculidae & Geococcyx californianus & greater roadrunner & $x$ & & & & & & & & \\
\hline Strigiformes & & & & & & & & & & & \\
\hline Tytonidae & Tyto alba & barn owl & $X$ & & & & & & & & \\
\hline Strigidae & Megascops kennicottii & western screech-owl & $\mathrm{x}$ & & & & & & & & \\
\hline & Bubo virginianus & great horned owl & $\mathrm{x}$ & & & & & & & & \\
\hline & $\begin{array}{l}\text { Glaucidium brasilianum } \\
\text { cactorum }\end{array}$ & $\begin{array}{l}\text { cactus ferruginous } \\
\text { pygmy-owl }\end{array}$ & $\mathrm{x}$ & & $\mathrm{x}$ & LE & & & $\mathrm{x}$ & & \\
\hline & Athene cunicularia hypuga & burrowing owl & $\mathrm{x}$ & & & SC & $x$ & & & & \\
\hline & Micrathene whitneyi & elf owl & $\mathrm{x}$ & & $\mathrm{X}$ & & & & & & $\mathrm{x}$ \\
\hline & Asio otus & long-eared owl & $\mathrm{x}$ & & & & & & & & \\
\hline & Aegolius acadicus & northern saw-whet owl & $\mathrm{x}$ & & & & & & & & \\
\hline Caprimulgifo & nes & & & & & & & & & & \\
\hline Caprimulgid & Chordeiles acutipennis & lesser nighthawk & $\mathrm{X}$ & & & & & & & & \\
\hline & Phalaenoptilus nuttalliii & common poorwill & $x$ & & $\mathrm{X}$ & & & & & & \\
\hline & Caprimulgus ridgwayi & buff-collared nightjar & & & $\mathrm{x}$ & & & & & & \\
\hline Apodiformes & & & & & & & & & & & \\
\hline Apodidae & Chaetura vauxi & Vaux's swift & $\mathrm{X}$ & & & & & & & & \\
\hline & Aeronautes saxatalis & white-throated swift & $\mathrm{x}$ & & & & & & & & \\
\hline Trochilidae & Cynanthus latirostris & broad-billed hummingbird & $\mathrm{X}$ & & & & & & & & \\
\hline & Archilochus alexandri & black-chinned hummingbird & $x$ & & & & & & & & \\
\hline & Calypte anna & Anna's hummingbird & $\mathrm{X}$ & & & & & & & & \\
\hline & Calypte costae & Costa's hummingbird & $\mathrm{X}$ & & & & & & & $\mathrm{x}$ & \\
\hline & Stellula calliope & calliope hummingbird & $\mathrm{X}$ & & & & & & & & \\
\hline & Selasphorus platycercus & broad-tailed hummingbird & $\mathrm{x}$ & & & & & & & & \\
\hline & Selasphorus rufus & rufous hummingbird & $x$ & & & & & & & & \\
\hline & Selasphorus sasin & Allen's hummingbird & $x$ & & & & & & & & \\
\hline Coraciiforme & & & & & & & & & & & \\
\hline Alcedinidae & Ceryle alcyon & belted kingfisher & $x$ & & & & & & $x$ & & \\
\hline Piciformes & & & & & & & & & & & \\
\hline Picidae & Melanerpes lewis & Lewis's woodpecker & $x$ & & & & & & & & \\
\hline & Melanerpes formicivorus & acorn woodpecker & $x$ & & & & & & & & \\
\hline & Melanerpes uropygialis & Gila woodpecker & $\mathrm{X}$ & & $\mathrm{X}$ & & & & & & $\mathrm{X}$ \\
\hline
\end{tabular}




\begin{tabular}{|c|c|c|c|c|c|c|c|c|c|c|c|}
\hline $\begin{array}{l}\text { Order } \\
\text { Family }\end{array}$ & Scientific name & Common name & Gros & $T \& D$ & $\mathrm{BE}$ & $E S A^{a}$ & $\mathrm{BLM}^{\mathrm{b}}$ & USFS $^{c}$ & $A Z^{d}$ & $\mathrm{APF}^{\mathrm{e}}$ & USFWS \\
\hline \multicolumn{12}{|l|}{ Piciformes } \\
\hline \multirow[t]{6}{*}{ Picidae } & Sphyrapicus varius & yellow-bellied sapsucker & $x$ & & & & & & & & \\
\hline & Sphyrapicus nuchalis & red-naped sapsucker & & $\mathrm{x}$ & & & & & & & \\
\hline & Sphyrapicus ruber & red-breasted sapsucker & $\mathrm{x}$ & & & & & & & & \\
\hline & Picoides scalaris & ladder-backed woodpecker & $\mathrm{X}$ & & & & & & & & \\
\hline & Colaptes auratus & northern flicker & $\mathrm{X}$ & & & & & & & & \\
\hline & Colaptes chrysoides & gilded flicker & & $x$ & $x$ & & & & & $x$ & $\mathrm{x}$ \\
\hline \multicolumn{12}{|c|}{ Passeriformes } \\
\hline \multirow[t]{19}{*}{ Tyrannidae } & Camptostoma imberbe & northern beardless-tyrannule & & $x$ & & & & & & & \\
\hline & Contopus cooperi & olive-sided flycatcher & $\mathrm{x}$ & & & SC & & & & & \\
\hline & Contopus sordidulus & western wood-pewee & $\mathrm{x}$ & & & & & & & & \\
\hline & Empidonax traillii & willow flycatcher & $\mathrm{x}$ & & $x$ & & & & $\mathrm{x}$ & & \\
\hline & Empidonax hammondii & Hammond's flycatcher & $x$ & & & & & & & & \\
\hline & Empidonax wrightii & gray flycatcher & $x$ & & & & & & & & \\
\hline & Empidonax occidentalis & cordilleran flycatcher & & $x$ & & & & & & & \\
\hline & Sayornis nigricans & black phoebe & $x$ & & & & & & & & \\
\hline & Sayornis phoebe & eastern phoebe & $\mathrm{x}$ & & & & & & & & \\
\hline & Sayornis saya & Say's phoebe & $x$ & & & & & & & & \\
\hline & Pyrocephalus rubinus & vermilion flycatcher & $x$ & & & & & & & & \\
\hline & Myiarchus cinerascens & ash-throated flycatcher & X & & $x$ & & & & & & \\
\hline & Myiarchus nuttingi & Nutting's flycatcher & & & $x$ & & & & & & \\
\hline & Myiarchus tyrannulus & brown-crested flycatcher & $\mathrm{x}$ & & $x$ & & & & & & \\
\hline & Tyrannus melancholicus & tropical kingbird & $x$ & & & & & & $\mathrm{x}$ & & \\
\hline & Tyrannus vociferans & Cassin's kingbird & $x$ & & & & & & & & \\
\hline & Tyrannus crassirostris & thick-billed kingbird & X & & & & & & $\mathrm{x}$ & & \\
\hline & Tyrannus verticalis & western kingbird & $x$ & & & & & & & & \\
\hline & Tyrannus forficatus & scissor-tailed flycatcher & $x$ & & & & & & & & \\
\hline Laniidae & Lanius ludovicianus & loggerhead shrike & $x$ & & & SC & & $x$ & & & \\
\hline \multirow[t]{5}{*}{ Vireonidae } & Vireo bellii & Bell's vireo & $x$ & & $x$ & & & $x$ & & & $\mathrm{x}$ \\
\hline & Vireo vicinior & gray vireo & $\mathrm{X}$ & & & & & & & & \\
\hline & Vireo huttoni & Hutton's vireo & $x$ & & & & & & & & \\
\hline & Vireo gilvus & warbling vireo & $x$ & & & & & & & & \\
\hline & Vireo olivaceus & red-eyed vireo & $x$ & & & & & & & & \\
\hline \multirow[t]{4}{*}{ Corvidae } & Cyanocitta stelleri & Steller's jay & $x$ & & & & & & & & \\
\hline & Aphelocoma californica & western scrub-jay & $\mathrm{x}$ & & & & & & & & \\
\hline & Nucifraga columbiana & Clark's nutcracker & $\mathrm{x}$ & & & & & & & & \\
\hline & Corvus corax & common raven & X & & & & & & & & \\
\hline Alaudidae & Eremophila alpestris & horned lark & $x$ & & & & & & & & \\
\hline \multirow[t]{7}{*}{ Hirundinidae } & Progne subis & purple martin & $\mathrm{X}$ & & & & & & & $x$ & \\
\hline & Tachycineta bicolor & tree swallow & $x$ & & & & & & & & \\
\hline & Tachycineta thalassina & violet-green swallow & $x$ & & & & & & & & \\
\hline & Stelgidopteryx serripennis & $\begin{array}{l}\text { northern rough-winged } \\
\text { swallow }\end{array}$ & $x$ & & & & & & & & \\
\hline & Riparia riparia & bank swallow & $x$ & & & & & & & & \\
\hline & Petrochelidon pyrrhonota & cliff swallow & $x$ & & & & & & & & \\
\hline & Hirundo rustica & barn swallow & $x$ & & & & & & & & \\
\hline Remizidae & Auriparus flaviceps & verdin & $x$ & & $\mathrm{x}$ & & & & & & \\
\hline Aegithalidae & Psaltriparus minimus & bushtit & $x$ & & & & & & & & \\
\hline Sittidae & Sitta canadensis & red-breasted nuthatch & X & & & & & & & & \\
\hline Certhiidae & Certhia americana & brown creeper & $x$ & & & & & & & & \\
\hline Troglodytidae & $\begin{array}{l}\text { Campylorhynchus } \\
\text { brunneicapillus }\end{array}$ & cactus wren & $x$ & & $\mathrm{X}$ & & & & & & \\
\hline
\end{tabular}




\begin{tabular}{|c|c|c|c|c|c|c|c|c|c|c|c|}
\hline \multicolumn{12}{|l|}{ Order } \\
\hline Family & Scientific name & Common name & Gros & $T \& D$ & $\mathrm{BE}$ & $E S A^{a}$ & $\mathrm{BLM}^{\mathrm{b}}$ & USFS $^{c}$ & $A Z^{d}$ & $\mathrm{APF}^{\mathrm{e}}$ & USFWS ${ }^{f}$ \\
\hline \multicolumn{12}{|l|}{ Passeriformes } \\
\hline \multirow[t]{5}{*}{ Troglodytidae } & Salpinctes obsoletus & rock wren & $\mathrm{x}$ & & & & & & & & \\
\hline & Catherpes mexicanus & canyon wren & $\mathrm{X}$ & & $\mathrm{X}$ & & & & & & \\
\hline & Thryomanes bewickii & Bewick's wren & $x$ & & & & & & & & \\
\hline & Troglodytes aedon & house wren & $x$ & & & & & & & & \\
\hline & Cistothorus palustris & marsh wren & $x$ & & & & & & & & \\
\hline \multirow[t]{2}{*}{ Regulidae } & Regulus satrapa & golden-crowned kinglet & $\mathrm{x}$ & & & & & & & & \\
\hline & Regulus calendula & ruby-crowned kinglet & $x$ & & & & & & & & \\
\hline \multirow[t]{2}{*}{ Sylviidae } & Polioptila caerulea & blue-gray gnatcatcher & $x$ & & & & & & & & \\
\hline & Polioptila melanura & black-tailed gnatcatcher & $X$ & & $X$ & & & & & & \\
\hline \multirow[t]{7}{*}{ Turdidae } & Sialia mexicana & western bluebird & $\mathrm{x}$ & & & & & & & & \\
\hline & Sialia currucoides & mountain bluebird & $\mathrm{X}$ & & & & & & & & \\
\hline & Myadestes townsendi & Townsend's solitaire & $x$ & & & & & & & & \\
\hline & Catharus ustulatus & Swainson's thrush & $x$ & & $\mathrm{X}$ & & & & & & \\
\hline & Catharus guttatus & hermit thrush & $x$ & & & & & & & & \\
\hline & Turdus migratorius & American robin & $x$ & & & & & & & & \\
\hline & Ixoreus naevius & varied thrush & $x$ & & & & & & & & \\
\hline \multirow[t]{7}{*}{ Mimidae } & Mimus polyglottos & northern mockingbird & $\mathrm{x}$ & & $\mathrm{x}$ & & & & & & \\
\hline & Oreoscoptes montanus & sage thrasher & $x$ & & & & & & & & \\
\hline & Toxostoma rufum & brown thrasher & $x$ & & & & & & & & \\
\hline & Toxostoma bendirei & Bendire's thrasher & $x$ & & & & & & & & \\
\hline & Toxostoma curvirostre & curve-billed thrasher & $\mathrm{X}$ & & $\mathrm{X}$ & & & & & & \\
\hline & Toxostoma crissale & crissal thrasher & $\mathrm{X}$ & & $x$ & & & & & & $\mathrm{x}$ \\
\hline & Toxostoma lecontei & Le Conte's thrasher & $x$ & & & & & & & & \\
\hline Sturnidae & Sturnus vulgaris & European starling & $x$ & & & & & & & & \\
\hline \multirow[t]{2}{*}{ Motacillidae } & Anthus rubescens & American pipit & $x$ & & & & & & & & \\
\hline & Anthus sprageii & Sprague's pipit & $x$ & & & & & & $\mathrm{x}$ & & $\mathrm{x}$ \\
\hline Bombycillidae & Bombycilla cedrorum & cedar waxwing & $x$ & & & & & & & & \\
\hline Ptilogonatidae & Phainopepla nitens & phainopepla & $X$ & & $\mathrm{x}$ & & & & & & \\
\hline \multirow[t]{21}{*}{ Parulidae } & Vermivora chrysoptera & golden-winged warbler & $x$ & & & & & & & & \\
\hline & Vermivora peregrina & Tennessee warbler & $x$ & & & & & & & & \\
\hline & Vermivora celata & orange-crowned warbler & $x$ & & & & & & & & \\
\hline & Vermivora ruficapilla & Nashville warbler & X & & & & & & & & \\
\hline & Vermivora virginiae & Virginia's warbler & $x$ & & & & & & & & \\
\hline & Vermivora luciae & Lucy's warbler & $\mathrm{X}$ & & $\mathrm{x}$ & & & & & $\mathrm{x}$ & \\
\hline & Dendroica petechia & yellow warbler & $x$ & & & & & & & & \\
\hline & Dendroica magnolia & magnolia warbler & $x$ & & & & & & & & \\
\hline & Dendroica caerulescens & black-throated blue warbler & $\mathrm{X}$ & & & & & & & & \\
\hline & Dendroica coronata & yellow-rumped warbler & $x$ & & & & & & & & \\
\hline & Dendroica nigrescens & black-throated gray warbler & $x$ & & & & & & & & \\
\hline & Dendroica virens & black-throated green warble & $\mathrm{rX}$ & & & & & & & & \\
\hline & Dendroica townsendi & Townsend's warbler & $x$ & & & & & & & & \\
\hline & Dendroica occidentalis & hermit warbler & $x$ & & & & & & & & \\
\hline & Dendroica graciae & Grace's warbler & $\mathrm{x}$ & & & & & & & & \\
\hline & Dendroica striata & blackpoll warbler & $x$ & & & & & & & & \\
\hline & Mniotilta varia & black-and-white warbler & $x$ & & & & & & & & \\
\hline & Setophaga ruticilla & American redstart & $x$ & & & & & & $\mathrm{x}$ & & \\
\hline & Seiurus aurocapilla & ovenbird & & $x$ & & & & & & & \\
\hline & Seiurus noveboracensis & northern waterthrush & $\mathrm{X}$ & & & & & & & & \\
\hline & Oporornis tolmiei & MacGillivray's warbler & $\mathrm{X}$ & & & & & & & & \\
\hline
\end{tabular}




\begin{tabular}{|c|c|c|c|c|c|c|c|c|c|c|c|}
\hline $\begin{array}{l}\text { Order } \\
\text { Family }\end{array}$ & Scientific name & Common name & Gros & $T \& D$ & $\mathrm{BE}$ & $E S A^{a}$ & $\mathrm{BLM}^{\mathrm{b}}$ & USFS $^{c}$ & $A Z^{d}$ & APF $^{\mathrm{e}}$ & USFWS ${ }^{\dagger}$ \\
\hline \multicolumn{12}{|l|}{ Passeriformes } \\
\hline \multirow[t]{4}{*}{ Parulidae } & Geothlypis trichas & common yellowthroat & $x$ & & & & & & & & \\
\hline & Wilsonia pusilla & Wilson's warbler & $\mathrm{x}$ & & & & & & & & \\
\hline & Myioborus pictus & painted redstart & $\mathrm{x}$ & & & & & & & & \\
\hline & Icteria virens & yellow-breasted chat & $\mathrm{x}$ & & $\mathrm{X}$ & & & & & & \\
\hline \multirow[t]{3}{*}{ Thraupidae } & Piranga rubra & summer tanager & $x$ & & & & & & & & \\
\hline & Piranga olivacea & scarlet tanager & $x$ & & & & & & & & \\
\hline & Piranga ludoviciana & western tanager & $x$ & & $\mathrm{X}$ & & & & & & \\
\hline \multirow[t]{18}{*}{ Emberizidae } & Pipilo chlorurus & green-tailed towhee & X & & $x$ & & & & & & \\
\hline & Pipilo maculatus & spotted towhee & $x$ & & & & & & & & \\
\hline & Pipilo fuscus & canyon towhee & $\mathrm{x}$ & & $\mathrm{x}$ & & & & & & \\
\hline & Pipilo aberti & Abert's towhee & $x$ & & & & & & & & \\
\hline & Aimophila carpalis & rufous-winged sparrow & $x$ & & & & & & & $\mathrm{x}$ & $\mathrm{X}$ \\
\hline & Aimophila cassinii & Cassin's sparrow & X & & & & & & & & \\
\hline & Aimophila ruficeps & rufous-crowned sparrow & $\mathrm{x}$ & & $\mathrm{X}$ & & & & & & \\
\hline & Spizella passerina & chipping sparrow & $x$ & & & & & & & & \\
\hline & Spizella pallida & clay-colored sparrow & $x$ & & & & & & & & \\
\hline & Spizella breweri & Brewer's sparrow & $x$ & & & & & & & & \\
\hline & Spizella atrogularis & black-chinned sparrow & $x$ & & & & & & & & \\
\hline & Passerculus sandwichensis & savannah sparrow & $\mathrm{X}$ & & & & & & & & \\
\hline & Pooecetes gramineus & vesper sparrow & $\mathrm{x}$ & & & & & & & & \\
\hline & Melospiza lincolnii & Lincoln's sparrow & $x$ & & & & & & & & \\
\hline & Chondestes grammacus & lark sparrow & $x$ & & & & & & & & \\
\hline & Melospiza georgiana & swamp sparrow & $\mathrm{x}$ & & & & & & & & \\
\hline & Amphispiza bilineata & black-throated sparrow & $x$ & & $\mathrm{X}$ & & & & & & \\
\hline & Amphispiza belli & sage sparrow & X & & & & & & & & \\
\hline \multirow[t]{8}{*}{ Emberizidae } & Calamospiza melanocorys & lark bunting & $x$ & & & & & & & & \\
\hline & Ammodramus savannarum & grasshopper sparrow & $x$ & & & & & & & & \\
\hline & Passerella iliaca & fox sparrow & $x$ & & & & & & & & \\
\hline & Melospiza melodia & song sparrow & $x$ & & & & & & & & \\
\hline & Zonotrichia albicollis & white-throated sparrow & $x$ & & & & & & & & \\
\hline & Zonotrichia leucophrys & white-crowned sparrow & $\mathrm{X}$ & & & & & & & & \\
\hline & Zonotrichia atricapilla & golden-crowned sparrow & $x$ & & & & & & & & \\
\hline & Junco hyemalis & dark-eyed junco & $x$ & & & & & & & & \\
\hline \multirow[t]{10}{*}{ Cardinalidae } & Cardinalis cardinalis & northern cardinal & $x$ & & $x$ & & & & & & \\
\hline & Cardinalis sinuatus & pyrrhuloxia & $x$ & & $x$ & & & & & & \\
\hline & Pheucticus ludovicianus & rose-breasted grosbeak & $x$ & & & & & & & & \\
\hline & Pheucticus melanocephalus & black-headed grosbeak & $x$ & & $x$ & & & & & & \\
\hline & Passerina caerulea & blue grosbeak & $x$ & & & & & & & & \\
\hline & Passerina amoena & lazuli bunting & $x$ & & & & & & & & \\
\hline & Passerina cyanea & indigo bunting & $X$ & & & & & & & & \\
\hline & Passerina versicolor & varied bunting & $\mathrm{X}$ & & $x$ & & & & & & \\
\hline & Passerina ciris & painted bunting & $x$ & & & & & & & & \\
\hline & Spiza americana & dickcissel & $x$ & & & & & & & & \\
\hline \multirow[t]{5}{*}{ Icteridae } & Agelaius phoeniceus & red-winged blackbird & $x$ & & & & & & & & \\
\hline & Sturnella magna lilianae & eastern meadowlark & X & & & & & & & & \\
\hline & Sturnella neglecta & western meadowlark & $x$ & & & & & & & & \\
\hline & $\frac{\text { Xanthocephalus }}{\text { xanthocephalus }}$ & yellow-headed blackbird & $\mathrm{X}$ & & & & & & & & \\
\hline & Euphagus cyanocephalus & Brewer's blackbird & $\mathrm{X}$ & & & & & & & & \\
\hline
\end{tabular}




\begin{tabular}{|c|c|c|c|c|c|c|c|c|c|c|c|}
\hline $\begin{array}{l}\text { Order } \\
\text { Family }\end{array}$ & Scientific name & Common name & Gros & $T \& D$ & $\mathrm{BE}$ & $\mathrm{ESA}^{\mathrm{a}}$ & $\mathrm{BLM}^{\mathrm{b}}$ & USFS $^{c}$ & $A Z^{d}$ & $\mathrm{APF}^{\mathrm{e}}$ & USFWS $^{\dagger}$ \\
\hline \multicolumn{12}{|c|}{ Passeriformes } \\
\hline \multirow[t]{6}{*}{ Icteridae } & Quiscalus mexicanus & great-tailed grackle & $X$ & & & & & & & & \\
\hline & Molothrus aeneus & bronzed cowbird & $X$ & & $X$ & & & & & & \\
\hline & Molothrus ater & brown-headed cowbird & $\mathrm{X}$ & & $x$ & & & & & & \\
\hline & Icterus cucullatus & hooded oriole & $X$ & & $\mathrm{X}$ & & & & & & \\
\hline & Icterus bullockii & Bullock's oriole & $X$ & & $x$ & & & & & & \\
\hline & Icterus parisorum & Scott's oriole & $X$ & & $X$ & & & & & & \\
\hline \multirow[t]{7}{*}{ Fringillidae } & Carpodacus purpureus & purple finch & $X$ & & & & & & & & \\
\hline & Carpodacus mexicanus & house finch & $x$ & & $x$ & & & & & & \\
\hline & Carduelis pinus & pine siskin & $X$ & & & & & & & & \\
\hline & Carduelis psaltria & lesser goldfinch & $X$ & & $X$ & & & & & & \\
\hline & Carduelis lawrencei & Lawrence's goldfinch & $X$ & & & & & & & & \\
\hline & Carduelis tristis & American goldfinch & $x$ & & & & & & & & \\
\hline & Coccothraustes vespertinus & evening grosbeak & $x$ & & & & & & & & \\
\hline Passeridae & Passer domesticus & house sparrow & $x$ & & & & & & & & \\
\hline
\end{tabular}

a "SC" = "Species of Concern"; "LE" = "Listed as Endangered" under the Endangered Species Act (HDMS 2004).

b "Sensitive" species; Bureau of Land Management (HDMS 2004).

c "Sensitive" species; USDA Forest Service (HDMS 2004).

d "Wildlife Species of Concern"; Arizona Game and Fish Department (HDMS 2004).

e "Priority" species; Arizona Partners in Flight (Latta et al. 1999).

f "Bird of Conservation concern"; U.S. Fish and Wildlife Service (2002). 

Appendix D. Mammal species recorded at Organ Pipe Cactus NM based on list by Cockrum and Petryszyn (1986; C\&P),
the Organ Pipe Cactus National Monument Ecological Monitoring Program (NPS 1998a and b; EMP), and voucher
specimens (Appendix F). Species in bold-faced type is non-native.

\begin{tabular}{|c|c|c|c|c|c|c|c|c|c|}
\hline $\begin{array}{l}\text { Order } \\
\text { Family }\end{array}$ & Scientific name & Common name & $\mathrm{ESA}^{\mathrm{a}}$ & $\mathrm{BLM}^{\mathrm{b}}$ & USFS $^{c}$ & $A Z G \& F^{d}$ & App G & C\&P & EMP \\
\hline \multicolumn{10}{|l|}{ Insectivora } \\
\hline Soricidae & Notiosorex crawfordi & Crawford's desert shrew & & & & & $X$ & $X$ & \\
\hline \multicolumn{10}{|l|}{ Chiroptera } \\
\hline \multirow[t]{3}{*}{ Phyllostomidae } & Macrotus californicus & California leaf-nosed bat & SC & $X$ & & $X$ & $X$ & $X$ & $X$ \\
\hline & Choeronycteris mexicana & Mexican long-tongued bat & SC & $X$ & & $X$ & & & $x$ \\
\hline & Leptonycteris curasoae & Lesser (southern) long-nosed bat & $\mathrm{LE}$ & & $X$ & $x$ & $X$ & $X$ & $x$ \\
\hline \multirow[t]{7}{*}{ Vespertilionidae } & Myotis velifer & cave myotis & SC & $X$ & & & $x$ & $X$ & $x$ \\
\hline & Myotis californicus & California myotis & & & & & $X$ & $X$ & $x$ \\
\hline & Pipistrellus hesperus & western pipistrelle & & & & & $X$ & $X$ & $x$ \\
\hline & Eptesicus fuscus & big brown bat & & & & & $x$ & $x$ & $x$ \\
\hline & Lasiurus cinereus & hoary bat & & & & & $X$ & $X$ & $x$ \\
\hline & Corynorhinus townsendii & Townsend's big-eared bat & SC & & & & $x$ & $X$ & $x$ \\
\hline & Antrozous pallidus & pallid bat & & & & & $x$ & $x$ & $x$ \\
\hline \multirow[t]{4}{*}{ Molossidae } & Tadarida brasiliensis & Brazilian free-tailed bat & & & & & & $X$ & $x$ \\
\hline & Nyctinomops femorosaccus & pocketed free-tailed bat & & $X$ & & & $x$ & $x$ & $x$ \\
\hline & Eumops perotis & western bonneted bat & SC & & & & $x$ & & \\
\hline & Eumops underwoodi & Underwood's bonneted bat & SC & $X$ & & & $x$ & $X$ & $x$ \\
\hline \multicolumn{10}{|l|}{ Carnivora } \\
\hline \multirow[t]{2}{*}{ Procyonidae } & Procyon lotor & northern raccoon & & & & & & $X$ & \\
\hline & Bassariscus astutus & ringtail & & & & & & $X$ & \\
\hline Mustelidae & Taxidea taxus & American badger & & & & & $X$ & $X$ & \\
\hline \multirow[t]{3}{*}{ Mephitidae } & Spilogale gracilis & western spotted skunk & & & & & & $X$ & \\
\hline & Mephitis mephitis & striped skunk & & & & & & $X$ & \\
\hline & Conepatus mesoleucus & white-backed hog-nosed skunk & & & & & & $X$ & \\
\hline \multirow[t]{4}{*}{ Canidae } & Canis familiaris & feral dog & & & & & $x$ & & \\
\hline & Canis latrans & coyote & & & & & $x$ & $X$ & \\
\hline & Vulpes macrotis & kit fox & & & & & $X$ & $X$ & \\
\hline & Urocyon cinereoargenteus & common gray fox & & & & & $x$ & $x$ & \\
\hline \multirow[t]{2}{*}{ Felidae } & Puma concolor & mountian lion & & & & & & $X$ & \\
\hline & Lynx rufus & bobcat & & & & & & $X$ & \\
\hline \multicolumn{10}{|l|}{ Rodentia } \\
\hline \multirow[t]{3}{*}{ Sciuridae } & Spermophilus variegatus & rock squirrel & & & & & & $x$ & \\
\hline & Spermophilus tereticaudus & round-tailed ground squirrel & & & & & $X$ & $x$ & \\
\hline & Ammospermophilus harrisii & Harris' antelope squirrel & & & & & $x$ & $x$ & \\
\hline Geomyidae & Thomomys bottae & Botta's pocket gopher & & & & & $x$ & $x$ & \\
\hline \multirow[t]{6}{*}{ Heteromyidae } & Perognathus amplus & Arizona pocket mouse & & & & & $X$ & $X$ & $X$ \\
\hline & Perognathus longimembris & little pocket mouse & & & & & $x$ & $x$ & \\
\hline & Chaetodipus penicillatus & Sonoran Desert pocket mouse & & & & & $X$ & $x$ & $X$ \\
\hline & Chaetodipus intermedius & rock pocket mouse & SC & & & & $X$ & $X$ & $x$ \\
\hline & Chaetodipus baileyi & Bailey's pocket mouse & & & & & $x$ & $X$ & $x$ \\
\hline & Dipodomys deserti & desert kangaroo rat & & & & & $X$ & $X$ & \\
\hline \multirow[t]{2}{*}{ Heteromyidae } & Dipodomys spectabilis & banner-tailed kangaroo rat & & & & & $x$ & $x$ & $X$ \\
\hline & Dipodomys merriami & Merriam's kangaroo rat & & & & & $X$ & $X$ & $X$ \\
\hline \multirow[t]{4}{*}{ Muridae } & Peromyscus eremicus & cactus mouse & SC & & $x$ & & $X$ & $X$ & $X$ \\
\hline & Peromyscus merriami & Merriam's mouse & & & & & $X$ & $X$ & \\
\hline & Peromyscus boylii & brush mouse & & & & & & & \\
\hline & Onychomys torridus & southern grasshopper mouse & & & & & & $X$ & $X$ \\
\hline
\end{tabular}




\begin{tabular}{|c|c|c|c|c|c|c|c|c|c|}
\hline $\begin{array}{l}\text { Order } \\
\text { Family }\end{array}$ & Scientific name & Common name & $E A^{a}$ & $\mathrm{BLM}^{\mathrm{b}}$ & USFS $^{c}$ & $A Z G \& F^{d}$ & App G & C\&P & EMP \\
\hline \multicolumn{10}{|l|}{ Rodentia } \\
\hline \multirow[t]{3}{*}{ Muridae } & Neotoma albigula & western white-throated woodrat & & & & & $x$ & $x$ & $x$ \\
\hline & Neotoma devia & Arizona woodrat & & & & & & $x$ & \\
\hline & Sigmodon arizonae & Arizona cotton rat & & & & & $x$ & & $x$ \\
\hline \multicolumn{10}{|l|}{ Lagomorpha } \\
\hline \multirow[t]{3}{*}{ Leporidae } & Lepus alleni & antelope jackrabbit & & & & & & $X$ & \\
\hline & Lepus californicus & black-tailed jackrabbit & & & & & & $X$ & \\
\hline & Sylvilagus audubonii & desert cottontail & & & & & & $X$ & \\
\hline \multicolumn{10}{|l|}{ Artiodactyla } \\
\hline Bovidae & Ovis canadensis & desert bighorn sheep & & & & & $x$ & $x$ & \\
\hline Tayassuidae & Pecari tajacu & collared peccary & & & & & & $x$ & \\
\hline \multirow[t]{2}{*}{ Cervidae } & Odocoileus hemionus & mule deer & & & & & & $x$ & \\
\hline & Odocoileus virginianus & white-tailed deer & & & & & & $x$ & \\
\hline Antilocapridae & Antilocapra americana sonoriensis & Sonoran pronghorn & LE & & & & & $X$ & \\
\hline
\end{tabular}

a "SC" = "Species of Concern"; "LE" = "Listed as Endangered" under the Endangered Species Act (HDMS 2004).

b "Sensitive" species; Bureau of Land Management (HDMS 2004).

"Sensitive" species; USDA Forest Service (HDMS 2004).

d "Wildlife Species of Concern"; Arizona Game and Fish Department (HDMS 2004). 
Appendix E. Amphibian, reptile, and mammal species that may occur at Organ Pipe Cactus NM based on Rosen and Lowe (1996) and Cockrum and Petryszyn (1986).

\begin{tabular}{|c|c|c|c|c|}
\hline Class & Order & Family & Scientific name & Common name \\
\hline \multirow[t]{2}{*}{ Amphibian } & Anura & Hylidae & Pternohyla fodiens & northern casque-headed frog \\
\hline & & Microhylidae & Gastrophryne olivacea & Great Plains narrow-mouthed toad \\
\hline \multirow[t]{2}{*}{ Reptile } & Squamata & Xantusiidae & Xantusia vigilis & desert night lizard \\
\hline & & Anguidae & Elgaria kingii & Madrean alligator lizard \\
\hline \multirow[t]{16}{*}{ Mammal } & Chiroptera & Phyllostomidae & Choeronycteris mexicana & Mexican long-tongued bat \\
\hline & & Vespertilionidae & Myotis yumanensis & Yuma myotis \\
\hline & & & Myotis thysanodes & fringed myotis \\
\hline & & & Myotis leibii & eastern small-footed myotis \\
\hline & & & Lasiurus borealis & eastern red bat \\
\hline & & & Lasiurus ega & southern yellow bat \\
\hline & Carnivora & Ursidae & Ursus americanus & American black bear \\
\hline & & Procyonidae & Nasua narica & white-nosed coati \\
\hline & & Mephitidae & Mephitis macroura & hooded skunk \\
\hline & & Felidae & Panthera onca & jaguar \\
\hline & & & Herpailurus yaguarondi & jaguarundi \\
\hline & Rodentia & Muridae & Reithrodontomys megalotis & western harvest mouse \\
\hline & & & Reithrodontomys fulvescens & fulvous harvest mouse \\
\hline & & & Peromyscus maniculatus & deer mouse \\
\hline & & & Peromyscus crinitus & canyon mouse \\
\hline & & & Mus musculus & house mouse \\
\hline
\end{tabular}


Appendix F. Known vertebrate voucher specimens from Organ Pipe Cactus NM.

\begin{tabular}{|c|c|c|c|c|}
\hline $\begin{array}{l}\text { Taxon } \\
\text { Common name }\end{array}$ & Field collection number & Collection $^{a}$ & Date(s) & Primary collector(s) \\
\hline \multicolumn{5}{|l|}{ Amphibian } \\
\hline \multirow[t]{3}{*}{ Couch's spadefoot } & $65853-60$ & UCB & $08 / 25 / 55$ & J. D. Anderson \\
\hline & $90702-03$ & NHMLAC & & \\
\hline & 136423 & UM & $07 / 28 / 66$ & E. D. Brodie \\
\hline \multirow[t]{7}{*}{ Sonoran desert toad } & 91679 & CAS & $09 / 2 / 61$ & R. Bandar. D. Rentz \\
\hline & 8547 & INHS & $06 / 22 / 57$ & $\begin{array}{l}\text { P. W. Smith, D. M. Smith, } \\
\text { A. A. Smith }\end{array}$ \\
\hline & $65850-52$ & UCB & $08 / 25 / 55$ & J. D. Anderson \\
\hline & 87021,87035 & NHMLAC & & \\
\hline & 021798 & USNM & & E. A. Mearns \\
\hline & $10768-69$ & UA & $06 / 20 / 64$ & T. J. Cox \\
\hline & 133459,136394 & UM & $07 / 28 / 66$ & E. D. Brodie \\
\hline \multirow[t]{4}{*}{ red-spotted toad } & 52164 & UCB & $08 / 10 / 49$ & J.B. Gorman \\
\hline & $26269-70,88086-87$ & NHMLAC & & \\
\hline & $13324-27$ & UTEP & & \\
\hline & $\begin{array}{l}12022,13806-07,14919, \\
47945-46,50619\end{array}$ & UA & $\begin{array}{l}03 / 20 / 52,10 / 25 / 64,03 / 31 / 66 \\
10 / 22 / 87,09 / 03 / 90\end{array}$ & $\begin{array}{l}\text { C. H. Lowe., W. S. Creighton, } \\
\text { W. C. Sherbrooke, R. L. Bezy, } \\
\text { P. C. Rosen }\end{array}$ \\
\hline \multirow[t]{5}{*}{ Great Plains toad } & $91680-87,93807$ & CAS & 09/02/61 & R. Bandar, D. Rentz \\
\hline & $8550-51$ & INHS & $06 / 21 / 57$ & $\begin{array}{l}\text { P. W. Smith, D. M. Smith, } \\
\text { A. A. Smith }\end{array}$ \\
\hline & $52174-78,65848-49$ & UCB & $08 / 10 / 49,08 / 25 / 55$ & J. B. Gorman, J. D. Anderson \\
\hline & $42813,47665-67$ & UA & $06 / 11 / 52,08 / 09 / 77$ & W. H. Woodin, J. K. Cross \\
\hline & 136039 & UM & $07 / 28 / 66$ & E. D. Brodie \\
\hline bullfrog & 47960 & UA & $07 / 10 / 85$ & S. Julander \\
\hline \multicolumn{5}{|l|}{ Reptile } \\
\hline \multirow[t]{4}{*}{ western banded gecko } & $65696,80186-87$ & UCB & $08 / 25 / 55,04 / 19 / 62,03 / 25 / 64$ & J. D. Anderson, R. M. Gaffery \\
\hline & $3236,93440-42,93445-47$ & NHMLAC & $04 / 20 / 42$ & \\
\hline & $\begin{array}{l}1145,1155,1159,1162, \\
33797,47861,47907-08 \\
48619,50733\end{array}$ & UA & $\begin{array}{l}\text { 05/19/56, 04/27/51, 05/14/71, } \\
\text { 07/12/88, 05/10/88, 05/11/88, } \\
\text { 05/18/89, 08/25/97 }\end{array}$ & $\begin{array}{l}\text { K. Justice, D. L. Braun, } \\
\text { C. H. Lowe, P. C. Rosen, } \\
\text { T. VanDevender }\end{array}$ \\
\hline & $30277,73805-07$ & UI & $06 / 02 / 52,05 / 29 / 51$ & $\begin{array}{l}\text { D. M. Smith, P. W. Smith, F. A. } \\
\text { Shannon, H. K. Gloyd, R. Abbuhl }\end{array}$ \\
\hline $\begin{array}{l}\text { desert banded gecko } \\
\text { (C. v. variegates) }\end{array}$ & $5654,5908,5912-14$ & UI & $\begin{array}{l}03 / 29 / 49,08 / 02 / 48 \\
08 / 10 / 48,08 / 08 / 48\end{array}$ & M. M. Hensley, W. L. Berger \\
\hline Sonoran mud turtle & 27987, 27993, 27996 & UA & $\begin{array}{l}\text { 05/14/67, 05/23/65, } \\
04 / 10 / 65\end{array}$ & R. D. Krizman, T. J. Cox \\
\hline \multirow[t]{3}{*}{ desert iguana } & 115554 & NHMLAC & & \\
\hline & 021728,061376 & USNM & $07 / 4 / 18$ & A. B. Howell, E. A. Mearns \\
\hline & 50081 & UA & & P. C. Rosen \\
\hline common chuckwalla & 39807,48527 & UA & $06 / 4 / 53,08 / 31 / 89$ & Woodin, Larson, P. C. Rosen \\
\hline \multirow[t]{4}{*}{ eastern collared lizard } & $76641 \cdots \cdots$ & UCB & $07 / 20 / 63$ & R. G. Crippen \\
\hline & $3982-83,125984$ & NHMLAC & $04 / 21 / 42$ & \\
\hline & $\begin{array}{l}1511,35715,39904-05 \\
47868,48845-46\end{array}$ & UA & $\begin{array}{l}\text { 08/13/60, 04/14/73, 06/04/53, } \\
04 / 30 / 88,04 / 07 / 90\end{array}$ & $\begin{array}{l}\text { G. O. Gates, A. Cecil, R. Johnson, } \\
\text { Woodin, Larson, P. C. Rosen }\end{array}$ \\
\hline & $5898-99-\square$ & UI & $08 / 04 / 48$ & Hensley, Burger \\
\hline \multirow[t]{3}{*}{ long-nosed leopard lizard } & 4016,94703 & NHMLAC & $04 / 24 / 42$ & \\
\hline & 50080 & UA & $06 / 12 / 93$ & R. D. McCord \\
\hline & 5655 & UI & $05 / 02 / 49$ & D. M. Smith, M. Hensley \\
\hline
\end{tabular}




\begin{tabular}{|c|c|c|c|c|}
\hline $\begin{array}{l}\text { Taxon } \\
\text { Common name }\end{array}$ & Field collection number & Collection $^{a}$ & Date(s) & Primary collector(s) \\
\hline \multicolumn{5}{|l|}{ Reptile } \\
\hline \multirow[t]{7}{*}{ zebra-tailed lizard } & $62598-00$ & Har & & \\
\hline & 65684 & UCB & $08 / 20 / 55$ & J. D. Anderson \\
\hline & $8787-89,94043$ & NHMLAC & $05 / 13 / 66$ & \\
\hline & $\begin{array}{l}40,66-67,111,137,10470, \\
12665-66,28440-41, \\
37865-67,40732,40734, \\
42605,47290,47873-74, \\
48620,49077\end{array}$ & UA & $\begin{array}{l}08 / 06 / 49,05 / 10 / 56,05 / 20 / 56 \\
04 / 30 / 55,10 / 12 / 63,10 / 25 / 64 \\
04 / 12 / 68,08 / 07 / 68,04 / 27 / 75 \\
07 / 19 / 77,06 / 04 / 53,04 / 30 / 88 \\
07 / 02 / 89,05 / 11 / 91\end{array}$ & $\begin{array}{l}\text { P. J. Lardner, R. C. Snyder, C. A. } \\
\text { Reed, W. C. Sherbrooke, R. L. } \\
\text { Bezy, D. Mulford, R. Small, S.Hale, } \\
\text { J. K. Cross, W. H. Woodin, P. C. } \\
\text { Rosen, C. H. Lowe, D. A.Parizek, } \\
\text { K. E. Justice, R. E.Carpenter }\end{array}$ \\
\hline & $\begin{array}{l}5943,35783-86,35794 \\
35878,74520-21\end{array}$ & Ul & $07 / 30 / 48,06 / 15 / 54,08 / 05 / 48$ & $\begin{array}{l}\text { D. M. Smith, H. M. Smith, } \\
\text { W. L. Burger, M. M. Hensley, } \\
\text { W. L. Burger, F. A. Shannon, } \\
\text { P. W. Smith, R. Abbuhl }\end{array}$ \\
\hline & $16953-54,32311$ & UC & $07 / 28 / 60,07 / 03 / 49$ & H. Beargie, K. Beargie, Wesselman \\
\hline & 5656 & UI & $07 / 03 / 49$ & M. M. Hensley \\
\hline \multirow[t]{3}{*}{ desert spiny lizard } & 8892,52935 & NHMLAC & $05 / 13 / 66$ & \\
\hline & $\begin{array}{l}12668,40706,42614 \\
47973,49142\end{array}$ & UA & $\begin{array}{l}\text { 10/25/64, 06/03/53, 07/18/77, } \\
09 / 17 / 88,04 / 13 / 91\end{array}$ & $\begin{array}{l}\text { W. C. Sherbrooke, R. L. Bezy, } \\
\text { Woodin, Larson, J. K. Cross, } \\
\text { P. C. Rosen, K. McLarnan }\end{array}$ \\
\hline & 35802 & UI & & $\begin{array}{l}\text { D. M. Smith, H. M. Smith, } \\
\text { W. L. Burger, M. M. Hensley }\end{array}$ \\
\hline \multirow[t]{5}{*}{ Clark's spiny lizard } & 44031 & UC & $04 / 01 / 67$ & R. L. Brown, R. Holland \\
\hline & 80350,198288 & UCB & $07 / 20 / 63,06 / 24 / 73$ & $\begin{array}{l}\text { B. K. Sullivan, R. R. Montancci, } \\
\text { V. L. Vesterby }\end{array}$ \\
\hline & 17378 & NHMLAC & & \\
\hline & $\begin{array}{l}2267,2272,12646-47 \\
12669,27151,40702,47872\end{array}$ & UA & $\begin{array}{l}06 / 08 / 51,04 / 30 / 55,10 / 25 / 64 \\
10 / 25 / 64,04 / 14 / 73,06 / 04 / 53 \\
04 / 30 / 88\end{array}$ & $\begin{array}{l}\text { C. H. Lowe, D. Mulford, } \\
\text { W. C.Sherbrooke, R. L. Bezy, } \\
\text { R. J. Johnson, Woodin, Larson, } \\
\text { P. C.Rosen }\end{array}$ \\
\hline & $35804-10$ & UI & $08 / 4 / 48$ & $\begin{array}{l}\text { D. M. Smith, H. M. Smith, } \\
\text { W. L. Burger, M. M. Hensley }\end{array}$ \\
\hline \multirow{6}{*}{$\begin{array}{l}\text { common side-blotched } \\
\text { lizard }\end{array}$} & 16586,76653 & UCB & $01 / 30 / 34,07 / 20 / 63$ & L. Kellogg, R. G. Cripper \\
\hline & $5526,98174-75,98182$ & NHMLAC & $04 / 24 / 42$ & \\
\hline & 27091-92 & TMNH & $09 / 07 / 66$ & W. B. Rhoten \\
\hline & $\begin{array}{l}6893,10467-68,11415 \\
12580,12658-61,40738 \\
41817-18,48558\end{array}$ & UA & $\begin{array}{l}\text { 05/01/55, 10/12/63, 04/30/56, } \\
\text { 04/14/63, 10/25/64, 04/27/75, } \\
06 / 06 / 53,06 / 11 / 52,06 / 02 / 89\end{array}$ & $\begin{array}{l}\text { P. J. Lardner, C. H. Lowe, } \\
\text { J. Wright, W. C. Sherbrooke, } \\
\text { R. L. Bezy, W. H. Woodin, Larson, } \\
\text { P. C. Larson, A. Thomas }\end{array}$ \\
\hline & $32483-87$ & UC & $06 / 19 / 64,04 / 06 / 66$ & Beargie, Wesselman, N. Hadley \\
\hline & $5657,5937-39,77880-81$ & $\mathrm{UI}$ & $\begin{array}{l}07 / 6 / 49,07 / 30 / 48,08 / 05 / 48 \\
06 / 15 / 54,05 / 29 / 51\end{array}$ & $\begin{array}{l}\text { M. Hensley, W. L. Burger, D. M. } \\
\text { Smith, F. A. Shannon, P. W. Smith, } \\
\text { R. Abbuhl, H. K. Gloyd }\end{array}$ \\
\hline striped plateau lizard & $166477-80$ & UM & $07 / 12 / 73$ & A. E. Dunham \\
\hline long-tailed brush lizard & 49081,49122 & UA & 05/11/91, 05/12/91 & C. H. Lowe, P. C. Rosen \\
\hline
\end{tabular}




\begin{tabular}{|c|c|c|c|c|}
\hline $\begin{array}{l}\text { Taxon } \\
\quad \text { Common name } \\
\end{array}$ & Field collection number & Collection $^{a}$ & Date(s) & Primary collector(s) \\
\hline \multicolumn{5}{|l|}{ Reptile } \\
\hline \multirow[t]{8}{*}{ ornate tree lizard } & NA & FWMSH & $04 / 01 / 64$ & \\
\hline & 16587,56757 & UCB & $01 / 29 / 34,04 / 30 / 52$ & M. M. Erickson, M. Larson \\
\hline & $76325-27,97942,123402$ & NHMLAC & & \\
\hline & 061398 & USNM & $07 / 03 / 18$ & A. B. Howell \\
\hline & $\begin{array}{l}3420,3422,3909,3911, \\
3942,3972,3993,4011 \\
4066,12649-53,40717 \\
40979,42038-41\end{array}$ & UA & $\begin{array}{l}10 / 25 / 64,08 / 13 / 60,04 / 30 / 55 \\
03 / 14 / 52,04 / 17 / 75,06 / 03 / 53 \\
06 / 06 / 53,06 / 11 / 52\end{array}$ & $\begin{array}{l}\text { W. C. Sherbrooke, R. L. Bezy, } \\
\text { G. O. Gates, A. D. Cecil, } \\
\text { D. Mulford, C. H. Lowe, } \\
\text { W. S.Creighton, J. J. Reed, } \\
\text { M. W. Larson, W. H. Woodin }\end{array}$ \\
\hline & $50572-76$ & UC & $06 / 19 / 64$ & Beargie, Wesselman \\
\hline & $\begin{array}{l}5915,5917-22,35800 \\
50699-01\end{array}$ & UI & $07 / 30 / 48,08 / 04 / 48,03 / 16 / 61$ & $\begin{array}{l}\text { D. M. Smith, H. M. Smith, } \\
\text { W. L. Burger, M. M. Hensley, } \\
\text { R. C. Schroeder }\end{array}$ \\
\hline & $166482-509$ & UM & $07 / 12 / 73$ & A. E. Dunham \\
\hline \multirow[t]{2}{*}{ desert horned lizard } & 4406,101597 & NHMLAC & & \\
\hline & $\begin{array}{l}2052,40220,40575,47931 \\
48771,50082,50148\end{array}$ & UA & $\begin{array}{l}04 / 28 / 51,04 / 27 / 75,10 / 03 / 87 \\
03 / 25 / 89,06 / 12 / 93,04 / 21 / 93\end{array}$ & C. H. Lowe, P. C. Rosen, E. B. Wirt \\
\hline \multirow[t]{4}{*}{ regal horned lizard } & SH.4005-06 & MSU & $07 / 20 / 61,07 / 21 / 61$ & R. G. Tuck \\
\hline & $101798-850$ & NHMLAC & & \\
\hline & 061381 & USNM & $07 / 02 / 18$ & A. B. Howell \\
\hline & $\begin{array}{l}40683,42593,47437 \\
47822,50202\end{array}$ & UA & $\begin{array}{l}06 / 10 / 52,07 / 08 / 77,09 / 13 / 87 \\
06 / 18 / 88,06 / 10 / 93\end{array}$ & $\begin{array}{l}\text { W. H. Woodin, J. K. Cross, } \\
\text { P. C. Rosen, R. D. McCord }\end{array}$ \\
\hline \multirow[t]{6}{*}{ canyon spotted whiptail } & $8586-87$ & INHS & $06 / 21 / 57,07 / 27 / 57$ & $\begin{array}{l}\text { P. W. Smith, D. M. Smith, } \\
\text { A. A. Smith, M. M. Hensley }\end{array}$ \\
\hline & $57047-48,76655,76779-81$ & UCB & 04/28/51, 06/09/51,07/20/63 & $\begin{array}{l}\text { C. H. Lowe, R. C. Stebbins, } \\
\text { R. G. Crippen }\end{array}$ \\
\hline & $75844,135450-51$ & NHMLAC & & \\
\hline & $\begin{array}{l}530,5566-68,5570-74 \\
5576-80,14110-11,43687 \\
47302-03,48344\end{array}$ & UA & $\begin{array}{l}04 / 28 / 55,04 / 30 / 55,06 / 09 / 51 \\
04 / 28 / 51,07 / 04 / 51,05 / 14 / 56 \\
06 / 24 / 62,10 / 25 / 64,10 / 25 / 64 \\
06 / 11 / 52,08 / 03 / 89\end{array}$ & $\begin{array}{l}\text { W. C. Sherbrooke, R. L. Bezy, } \\
\text { W. H. Woodin, E. B. Wirt, A. R. } \\
\text { Phillips, J. J. Reed, A. Thomas, } \\
\text { C. H. Lowe, K. E. Justice }\end{array}$ \\
\hline & $14627-29,14635$ & UC & $07 / 27 / 60,07 / 28 / 60$ & H. Beargie, K. Beargie \\
\hline & $104330-31,105426,166481$ & UM & $\begin{array}{l}07 / 18 / 50,06 / 09 / 51,06 / 09 / 51 \\
07 / 12 / 73\end{array}$ & W. E. Duellman, C. H. Lowe \\
\hline \multirow{6}{*}{$\begin{array}{l}\text { western whiptail } \\
\text { (tiger whiptail) }\end{array}$} & $13635-36$ & CAS1 & $05 / 02 / 54$ & H. K. Gloyd \\
\hline & 56746 & UCB & $04 / 30 / 52$ & M. Larson, L. Talbot \\
\hline & $9027-30,99979-82$ & NHMLAC & $05 / 13 / 66$ & \\
\hline & $\begin{array}{l}151-152,509-510,514-516, \\
5689,5781,5786,5825, \\
5868,5885,10469, \\
12569-79,28647,24607, \\
47821,48556,49393\end{array}$ & UA & $\begin{array}{l}08 / 06 / 49,04 / 15 / 51,04 / 28 / 51 \\
06 / 08 / 51,05 / 19 / 56,05 / 14 / 56 \\
08 / 13 / 60,05 / 01 / 55,10 / 12 / 63 \\
04 / 14 / 63,04 / 12 / 68,07 / 20 / 77 \\
06 / 17 / 88,05 / 20 / 89,04 / 13 / 91\end{array}$ & $\begin{array}{l}\text { P. J. Lardner, J. Wright, R. C. } \\
\text { Snyder, C. A. Reed, R. Small, J. K. } \\
\text { Cross, P. C. Rosen, R. D. McCord, } \\
\text { C. H. Lowe, K. Justice, G. O. } \\
\text { Gates, A. D. Cecil, C. D. Belknap, } \\
\text { J. J. Reed }\end{array}$ \\
\hline & $\begin{array}{l}14669-73,36355 \\
45468-80,55517-39\end{array}$ & UC & $\begin{array}{l}07 / 28 / 60,04 / 06 / 66,05 / 24 / 71 \\
06 / 04 / 82,06 / 05 / 82\end{array}$ & $\begin{array}{l}\text { H. Beargie, K. Beargie, N. Hadley, } \\
\text { D. M. Secoy, H. L. Taylor }\end{array}$ \\
\hline & 43217 & Ul & $06 / 27 / 58$ & $\begin{array}{l}\text { D. M. Smith, K. Williams, } \\
\text { J. P. Kelley }\end{array}$ \\
\hline western skink & $35788-90,35792-93$ & UI & 07/30/48, 08/01/48, 08/04/48 & $\begin{array}{l}\text { D. M. Smith, H. M. Smith, } \\
\text { W. L. Burger, M. M. Hensley }\end{array}$ \\
\hline \multirow[t]{4}{*}{ Gila monster } & 75109,93895 & NHMLAC & & \\
\hline & 72056 & TCWC & 06/18/86 & \\
\hline & $47961,50698,50729$ & UA & $05 / 16 / 87,09 / 05 / 96,08 / 25 / 97$ & K. Wisner, A. C. Pate, P. C. Rosen \\
\hline & $4976-3$ & NHMLAC & & \\
\hline
\end{tabular}




\begin{tabular}{|c|c|c|c|c|}
\hline $\begin{array}{l}\text { Taxon } \\
\quad \text { Common name } \\
\end{array}$ & Field collection number & Collection $^{\mathrm{a}}$ & Date(s) & Primary collector(s) \\
\hline \multicolumn{5}{|l|}{ Reptile } \\
\hline \multirow[t]{2}{*}{ western blind snake } & 47815 & UA & $06 / 12 / 88$ & P. C. Rosen \\
\hline & 5622 & UI & $07 / 2 / 49$ & D. M. Smith, M. Hensley \\
\hline \multirow[t]{2}{*}{ rosy boa } & $\begin{array}{l}\text { 39554-55, 47398, } \\
\text { 49396-PSV }\end{array}$ & UA & $\begin{array}{l}\text { 05/05/62, 11/29/52, 10/21/87, } \\
03 / 20 / 90\end{array}$ & $\begin{array}{l}\text { O. Bronson, J. Martin, } \\
\text { T. VanDevender, Baker, G. Ruffner, } \\
\text { R. Joh }\end{array}$ \\
\hline & 5623,6015 & UI & $04 / 11 / 49,08 / 09 / 48$ & $\begin{array}{l}\text { D. M. Smith, W. L. Burger, } \\
\text { M. Hensley }\end{array}$ \\
\hline western hog-nosed snake & $4069,4210-13$ & NHMLAC & $04 / 24 / 42$ & \\
\hline \multirow[t]{5}{*}{ spotted leaf-nosed snake } & CAS 91663 & CAS & 09/02/61 & R. Bandar \\
\hline & $8018-26$ & INHS & $06 / 14 / 55,07 / 27 / 57,06 / 20 / 57$ & $\begin{array}{l}\text { P. W. Smith, D. M. Smith } \\
\text { A. A. Smith, M. M. Hensley }\end{array}$ \\
\hline & $64236,102786-88$ & NHMLAC & & \\
\hline & $\begin{array}{l}33844,40815,42709, \\
47814,48544-45, \\
48569-70,49089-90,49925, \\
50093-94,50096,50100, \\
50180\end{array}$ & UA & $\begin{array}{l}05 / 14 / 71,06 / 09 / 55,07 / 09 / 77, \\
06 / 15 / 88,05 / 21 / 89,08 / 07 / 89, \\
06 / 26 / 89,05 / 27 / 89,05 / 24 / 90, \\
05 / 23 / 91,04 / 24 / 92,06 / 13 / 93, \\
06 / 10 / 93,06 / 12 / 93,06 / 14 / 93, \\
05 / 31 / 92\end{array}$ & $\begin{array}{l}\text { T. VanDevender, Woodin, } \\
\text { Koehler, J. K. Cross, P. C. Rosen, } \\
\text { J. B. Iverson, C. Wilson, S. Booth, } \\
\text { D. A. Parize, C. H. Lowe }\end{array}$ \\
\hline & $\begin{array}{l}5580-83,5585-88 \\
5967,84054-55\end{array}$ & Ul & $\begin{array}{l}04 / 24 / 49,06 / 09 / 49,06 / 14 / 49, \\
06 / 16 / 49,06 / 25 / 49,06 / 26 / 49, \\
07 / 28 / 48,05 / 29 / 51\end{array}$ & $\begin{array}{l}\text { D. M. Smith, M. M. Hensley, } \\
\text { W. L. Burger, F. A. Shannon, } \\
\text { Supernaugh, R. Abbuhl, } \\
\text { H. K. Gloyd }\end{array}$ \\
\hline \multirow[t]{8}{*}{ saddled leaf-nosed snake } & 41194 & BYU & $07 / 19 / 72$ & J.R. Ottley \\
\hline & $7576,8016-18$ & INHS & $06 / 17 / 54,06 / 14 / 55,07 / 31 / 57$ & $\begin{array}{l}\text { P. W. Smith, D. M. Smith, } \\
\text { A. A. Smith, M. M. Hensley }\end{array}$ \\
\hline & 62401 & Har & & \\
\hline & $53086-91,102778$ & NHMLAC & & \\
\hline & $193015,292589-90$ & USNM & $07 / 09 / 71$ & F. R. Gehlbach \\
\hline & $\begin{array}{l}25792,25811,33825-26, \\
39512,40349,41192,41466, \\
41478,42594,42613,47811, \\
48539,48541-42,48568, \\
49088,50088,50090, \\
50144-45,50178\end{array}$ & UA & $\begin{array}{l}04 / 30 / 56,06 / 24 / 62,05 / 14 / 71, \\
06 / 11 / 53,06 / 05 / 50,06 / 09 / 52, \\
06 / 12 / 52,06 / 10 / 52,07 / 07 / 77, \\
07 / 19 / 77,06 / 13 / 88,07 / 02 / 89, \\
08 / 07 / 89,05 / 25 / 89,06 / 11 / 93, \\
05 / 20 / 93,06 / 11 / 93,05 / 29 / 92\end{array}$ & $\begin{array}{l}\text { C. H. Lowe, R. L. Bezy, } \\
\text { T. VanDevender, W. H. Woodin, } \\
\text { D. L. Braun, W. H. Woodin, } \\
\text { J. K. Cross, P. C. Rosen, } \\
\text { S. J. Booth, B. E.Martin, S. F. Hale, } \\
\text { P. A. Holm, J. Howland }\end{array}$ \\
\hline & $40915--n$ & UC & $07 / 18 / 69$ & R. L. Holland \\
\hline & $\begin{array}{l}5568-71,5573-77,5579 \\
5648,5969-70,83993\end{array}$ & Ul & $\begin{array}{l}06 / 12 / 49,06 / 13 / 49,06 / 14 / 49, \\
06 / 16 / 49,06 / 17 / 49,06 / 18 / 49, \\
06 / 09 / 49,06 / 24 / 49,07 / 11 / 49, \\
07 / 20 / 49,08 / 02 / 48,09 / 09 / 48, \\
06 / 15 / 57\end{array}$ & $\begin{array}{l}\text { D. M. Smith, M. M. Hensley, } \\
\text { W. L. Burger, F. A. Shannon }\end{array}$ \\
\hline \multirow[t]{3}{*}{ coachwhip } & HE.13566 & MSU & $04 / 18 / 49$ & M. M. Hensley \\
\hline & $\begin{array}{l}25600,31757,37822-23 \\
48837-38\end{array}$ & UA & $\begin{array}{l}04 / 29 / 62,09 / 22 / 69,07 / 12 / 69 \\
05 / 08 / 83,05 / 06 / 89,05 / 07 / 89\end{array}$ & $\begin{array}{l}\text { R. L. Bezy, T. Mulroy, S. Hale, } \\
\text { R. R. Johnson, P. C. Rosen }\end{array}$ \\
\hline & $5610-3 \cdots \cdots$ & Ul & $05 / 12 / 49$ & D. M. Smith, M. Hensley \\
\hline Sonoran whipsnake & $\begin{array}{l}35512,39722,47370 \\
50195,50845-P S V\end{array}$ & UA & $\begin{array}{l}06 / 06 / 53,05 / 06 / 72,06 / 21 / 93 \\
09 / 23 / 73,06 / 04 / 53,09 / 22 / 69\end{array}$ & $\begin{array}{l}\text { W. H. Woodin, Johnson, D. A. } \\
\text { Parizek, B. E. Martin, Larson }\end{array}$ \\
\hline
\end{tabular}




\begin{tabular}{|c|c|c|c|c|}
\hline $\begin{array}{l}\text { Taxon } \\
\text { Common name }\end{array}$ & Field collection number & Collection $^{\mathrm{a}}$ & Date(s) & Primary collector(s) \\
\hline \multicolumn{5}{|l|}{ Reptile } \\
\hline \multirow[t]{6}{*}{ western patch-nosed snake } & 6502 & INHS & $06 / 02 / 52$ & $\begin{array}{l}\text { P. W. Smith, D. M. Smith, } \\
\text { A. A. Smith }\end{array}$ \\
\hline & HE. 13607 & MSU & $05 / 28 / 49$ & M. M. Hensley \\
\hline & $128211-12$ & UCB & $06 / 22 / 76,07 / 22 / 75$ & B. K. Sullivan, R. Garcia \\
\hline & $\begin{array}{l}26273,30640,40214, \\
40562,43007,45094, \\
47852,47884,47886, \\
47899-900,47976-77, \\
48530-31,48611,48691, \\
48765-66,48839-41,49281, \\
50184-86,50222,50316, \\
50591\end{array}$ & UA & $\begin{array}{l}\text { 04/30/56, 04/22/69, 05/24/50, } \\
06 / 03 / 53,07 / 06 / 78,11 / 27 / 83 \\
\text { 04/10/88, 05/21/88, 05/19/88, } \\
\text { 05/17/88, 04/16/88, 10/15/86, } \\
\text { 04/15/89, 05/13/89, 03/29/89, } \\
09 / 23 / 89,03 / 28 / 89,03 / 30 / 89 \\
05 / 08 / 89,05 / 06 / 89,05 / 12 / 91 \\
03 / 24 / 93,03 / 25 / 93,10 / 07 / 92 \\
05 / 03 / 95,10 / 18 / 96\end{array}$ & $\begin{array}{l}\text { C. H. Lowe, T. Mulroy, } \\
\text { W. H. Woodin, Larson, } \\
\text { J. K. Cross, R. R. Johnson, } \\
\text { P. C. Rosen, R. Irving, } \\
\text { D. Anderson, E. B. Wirt, } \\
\text { D. A. Parizek, T. R. Jones, } \\
\text { C. W. Connor, C. Hedgcock, } \\
\text { B. E. Martin }\end{array}$ \\
\hline & 31167 & UC & $04 / 3 / 66$ & R. Holland \\
\hline & $5561-67,30330$ & UI & $\begin{array}{l}03 / 28 / 49,04 / 04 / 49,04 / 10 / 49 \\
04 / 23 / 49,04 / 27 / 49,05 / 12 / 49 \\
06 / 11 / 49,06 / 02 / 49\end{array}$ & $\begin{array}{l}\text { D. M. Smith, P.W. Smith, A. Smith, } \\
\text { M. M. Hensley }\end{array}$ \\
\hline \multirow[t]{5}{*}{ gopher snake } & HE.13567 & MSU & $08 / 04 / 57$ & M. M. Hensley \\
\hline & 102199,102201 & NHMLAC & & \\
\hline & $\begin{array}{l}28828,47851,47957 \\
47962,47975,48560 \\
48836\end{array}$ & UA & $\begin{array}{l}\text { 06/24/68, 05/24/88, 09/17/88, } \\
\text { 08/26/86, 10/05/88, 06/15/89, } \\
\text { 05/09/89 }\end{array}$ & $\begin{array}{l}\text { P. Gegenheimer, P. C. Rosen, } \\
\text { M. Brown, E. B. Wirt, S. Booth }\end{array}$ \\
\hline & 5595,83892 & UI & $04 / 30 / 49,06 / 15 / 57$ & $\begin{array}{l}\text { D. M. Smith, F. A. Shannon, } \\
\text { F. L. Humphrey, M. M. Hensley }\end{array}$ \\
\hline & 135970 & UM & $07 / 28 / 66$ & E. D. Brodie \\
\hline \multirow[t]{4}{*}{ glossy snake } & 91674,92463 & CAS & $09 / 02 / 61,08 / 10 / 61$ & R. Bandar \\
\hline & 8607 & INHS & $06 / 12 / 57$ & P.W. Smith, D.M. Smith, A.A. Smith \\
\hline & $101977-78,101982-84$ & NHMLAC & & \\
\hline & $\begin{array}{l}23989,24035,33853, \\
41015,47807-08,47922-23, \\
48529,49082,50196\end{array}$ & UA & $\begin{array}{l}04 / 14 / 52,06 / 24 / 62,05 / 14 / 71 \\
06 / 15 / 88,06 / 13 / 88,09 / 13 / 87 \\
08 / 20 / 87,05 / 19 / 89,05 / 22 / 90 \\
06 / 10 / 93\end{array}$ & $\begin{array}{l}\text { T. J. Walker, R. L. Bezy, } \\
\text { T. VanDevender, L. Woodin, } \\
\text { P. C. Rosen, C. Connor, } \\
\text { R. D. McCord }\end{array}$ \\
\hline \multirow[t]{2}{*}{$\begin{array}{l}\text { Arizona glossy snake } \\
\text { (A. e. noctivaga) }\end{array}$} & $41019,42592,48561$ & UA & 05/10/50, 07/09/77, 05/27/89 & $\begin{array}{l}\text { W. H. Woodin, J. K. Cross, } \\
\text { S. Booth }\end{array}$ \\
\hline & $5590-93$ & Ul & $\begin{array}{l}03 / 26 / 49,05 / 12 / 49,07 / 02 / 49 \\
07 / 11 / 49\end{array}$ & D. M. Smith, \& M. Hensley \\
\hline \multirow[t]{2}{*}{ common kingsnake } & HE.13565 & MSU & $08 / 04 / 57$ & M. M. Hensley \\
\hline & $\begin{array}{l}40383,45466-67,47891 \\
47920,48767,49085 \\
50745\end{array}$ & UA & $\begin{array}{l}\text { 05/18/75, 05/09/85, 05/08/88, } \\
\text { 08/22/87, 08/19/88, 05/23/90, } \\
04 / 13 / 85\end{array}$ & $\begin{array}{l}\text { Wallace, T. VanDevender, } \\
\text { P. C. Rosen, E. B. Wirt, P. A. Holm }\end{array}$ \\
\hline \multirow[t]{4}{*}{ long-nosed snake } & CAS 91673 & CAS & 09/02/61 & R. Bandar \\
\hline & $34936,102599-602$ & NHMLAC & & \\
\hline & $\begin{array}{l}26090,41406,45524, \\
47853,47892-94,47896-98, \\
47901,47918-19,48532-37, \\
48564-65,48769-70, \\
50313-14\end{array}$ & UA & $\begin{array}{c}04 / 8 / 66,06 / 10 / 52,05 / 08 / 83 \\
05 / 22 / 88,05 / 11 / 88,05 / 09 / 88 \\
05 / 16 / 88,05 / 11 / 88,08 / 22 / 87 \\
08 / 23 / 87,05 / 04 / 89,04 / 21 / 89 \\
\text { 05/04/89, 04/21/89, 04/15/89, } \\
\text { 06/15/89, 05/27/89, 03/28/89, } \\
03 / 29 / 89,04 / 23 / 93,09 / 11 / 91\end{array}$ & $\begin{array}{l}\text { R. L. Bezy, W. H. Woodin, } \\
\text { R. R. Johnson, P. C. Rosen, } \\
\text { S. J. Booth, E. B. Wirt, V. Carrasco }\end{array}$ \\
\hline & 5600,5987 & UI & $04 / 21 / 49,07 / 31 / 48$ & $\begin{array}{l}\text { D. M. Smith, M. M. Hensley, } \\
\text { W. L. Burger }\end{array}$ \\
\hline black-necked garter snake & 76321 & NHMLAC & & \\
\hline western ground snake & 2702 & NHMLAC & & J. C. Von Bleeker \\
\hline
\end{tabular}




\begin{tabular}{|c|c|c|c|c|}
\hline $\begin{array}{l}\text { Taxon } \\
\text { Common name } \\
\end{array}$ & Field collection number & Collection $^{\mathrm{a}}$ & Date(s) & Primary collector(s) \\
\hline \multicolumn{5}{|l|}{ Reptile } \\
\hline \multirow{2}{*}{$\begin{array}{l}\text { western shovel-nosed } \\
\text { snake }\end{array}$} & 52199,64303 & NHMLAC & & \\
\hline & $39835,49094,49183$ & UA & 06/5/50, 05/11/91, 05/12/91 & $\begin{array}{l}\text { W. H. Woodin, P. C. Rosen, } \\
\text { C. H. Lowe }\end{array}$ \\
\hline \multirow{4}{*}{$\begin{array}{l}\text { Sonoran shovel-nosed } \\
\text { snake }\end{array}$} & HE.10735 & MSU & $06 / 11 / 49$ & M. M. Hensley \\
\hline & $\begin{array}{l}34915,52166-68 \\
67276,125992\end{array}$ & NHMLAC & $05 / 30 / 58$ & \\
\hline & $\begin{array}{l}20967,39834,39836, \\
45468-69,47818-20, \\
47854-58,47887-89, \\
47903-06,48231,48303, \\
48548-55,48574-75, \\
49616-17,48768,48842, \\
48874-75,49097-102, \\
49331,50103,50151-54, \\
50172,50199,50734\end{array}$ & UA & $\begin{array}{l}\text { 06/9/51, 07/07/56, 05/09/85, } \\
\text { 06/16/88, 06/17/88, 06/18/88, } \\
\text { 05/22/88, 05/23/88, 05/21/88, } \\
\text { 05/20/88, 05/08/88, 05/07/88, } \\
\text { 05/09/88, 05/06/88, 05/04/89, } \\
\text { 05/21/89, 04/21/89, 05/15/89, } \\
\text { 06/02/89, 07/01/89, 04/16/89, } \\
\text { 04/18/89, 06/09/89, 06/06/89, } \\
\text { 04/11/89, 08/19/88, 05/06/89, 05/29/89, } \\
\text { 05/21/91, 05/21/90, 05/13/91, 05/23/90, } \\
\text { 05/19/90, 09/19/87, 05/26/93, 05/12/93, } \\
04 / 19 / 93,05 / 20 / 93,06 / 09 / 91,06 / 16 / 93 \\
07 / 02 / 96\end{array}$ & $\begin{array}{l}\text { C. H. Lowe, O. Bronson, } \\
\text { R. B. Loomis, T. VanDevender, } \\
\text { P. C. Rosen, S. J. Booth, } \\
\text { E. B. Wirt, B. E. Martin, } \\
\text { Y. Petryszyn, J. S. Parizek, } \\
\text { D. A. Parizek, P. A. Holm, } \\
\text { S. S. Sartorius, C. W. Connor }\end{array}$ \\
\hline & $5602-06,5906$ & UI & $\begin{array}{l}06 / 19 / 49,06 / 12 / 49,06 / 17 / 49,06 / 20 / 49 \\
08 / 02 / 48\end{array}$ & $\begin{array}{l}\text { D. M. Smith, M. Hensley, } \\
\text { W. L. Buger }\end{array}$ \\
\hline \multirow[t]{2}{*}{ variable sandsnake } & $\begin{array}{l}42467,24102,47902, \\
48547,48876,49093 \\
49928,50328\end{array}$ & UA & $\begin{array}{l}06 / 01 / 52,05 / 11 / 88,04 / 21 / 89 \\
05 / 29 / 89,05 / 29 / 91,04 / 26 / 92 \\
10 / 01 / 95\end{array}$ & $\begin{array}{l}\text { Smith, Wallace, C. H. Lowe, } \\
\text { P. C. Rosen, E. B. Wirt, D. } \\
\text { Mello, S. Julander, P. A. Holm }\end{array}$ \\
\hline & $5608-09$ & UI & $06 / 19 / 49,07 / 11 / 49$ & D. M. Smith, M. Hensley \\
\hline $\begin{array}{l}\text { southwestern black- } \\
\text { headed snake }\end{array}$ & $48576-77$ & UA & $03 / 29 / 90,04 / 20 / 90$ & P. C. Rosen \\
\hline \multirow[t]{3}{*}{ western lyre snake } & 91672 & CAS & $09 / 02 / 61$ & R. Bandar \\
\hline & $\begin{array}{l}39593,47883-84 \\
49228,49428\end{array}$ & UA & $\begin{array}{l}\text { 05/17/50, 05/21/88, 05/19/90, } \\
10 / 04 / 90\end{array}$ & $\begin{array}{l}\text { W. H. Woodin, P. C. Rosen, } \\
\text { E. B. Wirt }\end{array}$ \\
\hline & $5618-20$ & UI & $07 / 02 / 49,07 / 03 / 49$ & D. M. Smith, M. M. Hensley \\
\hline \multirow[t]{4}{*}{ night snake } & 8027 & INHS & $06 / 14 / 55$ & P.W. Smith and D.M. Smith \\
\hline & $\begin{array}{l}63455,64308-09 \\
101826,115799\end{array}$ & NHMLAC & & \\
\hline & $\begin{array}{l}27150,39741,40386 \\
41223,42596,47817 \\
47972,48546,48571\end{array}$ & UA & $\begin{array}{l}04 / 14 / 73,06 / 11 / 52,05 / 18 / 75 \\
06 / 11 / 53,07 / 07 / 77,06 / 17 / 88 \\
09 / 16 / 88,07 / 01 / 89,04 / 19 / 90\end{array}$ & $\begin{array}{l}\text { R. J. Johnson, W. H. Woodin, } \\
\text { Wallace, Larson, J. K. Cross, } \\
\text { P. C. Rosen }\end{array}$ \\
\hline & $5614-17,47641-42$ & UI & $\begin{array}{l}05 / 13 / 49,06 / 11 / 49,06 / 12 / 49 \\
05 / 28 / 56\end{array}$ & $\begin{array}{l}\text { D. M. Smith, M. M. Hensley, } \\
\text { M. B. Mittleman }\end{array}$ \\
\hline \multirow[t]{2}{*}{ Sonoran coral snake } & 3197 & NHMLAC & & \\
\hline & $\begin{array}{l}39674,47959,47965 \\
48572-73,48692 \\
49086-87\end{array}$ & UA & $\begin{array}{l}\text { 09/17/88, 09/02/86, 05/29/89, } \\
\text { 05/27/89, 04/14/89, 05/17/91, } \\
\text { 05/23/90 }\end{array}$ & $\begin{array}{l}\text { P. C. Rosen, B. Mack, S. J. } \\
\text { Booth, E. B. Wirt }\end{array}$ \\
\hline \multirow{7}{*}{$\begin{array}{l}\text { western diamond-backed } \\
\text { rattlesnake }\end{array}$} & 92463 & CAS & $08 / 10 / 61$ & R. Bandar \\
\hline & 6513 & INHS & $06 / 2 / 52$ & W. Supernaugh \\
\hline & $\begin{array}{l}3014,34945, \\
104368-72,115981\end{array}$ & NHMLAC & $04 / 21 / 62$ & \\
\hline & 33321 & TCWC & & \\
\hline & 061624 & USNM & $07 / 3 / 18$ & A. B. Howell \\
\hline & $\begin{array}{l}27313-14,37320 \\
42698,47910-11 \\
48562-63,48610 \\
48686-87,48843,50170\end{array}$ & UA & $\begin{array}{l}08 / 6 / 64,05 / 06 / 65,08 / 09 / 77 \\
09 / 18 / 87,08 / 24 / 87,06 / 13 / 89 \\
04 / 20 / 89,09 / 23 / 89,08 / 18 / 88 \\
09 / 22 / 89,07 / 29 / 89,03 / 25 / 93\end{array}$ & $\begin{array}{l}\text { A. L. Gardner, T. J. Cox, } \\
\text { J. K. Cross, P. C. Rosen, } \\
\text { S. J. Booth, R. Johnson, K. } \\
\text { Hiett, E. B. Wirt, T. R. Jones }\end{array}$ \\
\hline & $5624-25$ & Ul & $04 / 11 / 49,07 / 04 / 49$ & D. M. Smith, M. Hensley \\
\hline
\end{tabular}




\begin{tabular}{|c|c|c|c|c|}
\hline $\begin{array}{l}\text { Taxon } \\
\text { Common name } \\
\end{array}$ & Field collection number & Collection $^{a}$ & Date(s) & Primary collector(s) \\
\hline \multicolumn{5}{|l|}{ Reptile } \\
\hline \multirow[t]{5}{*}{ sidewinder } & $52571,64281,104467-69$ & NHMLAC & & \\
\hline & 33329 & TCWC & & \\
\hline & 134309 & USNM & $06 / 26 / 49$ & M. Hensley \\
\hline & $\begin{array}{l}27443-46,27448-49, \\
27451,27453,27497,27958\end{array}$ & UA & $10 / 08 / 60,05 / 20 / 65,09 / 17 / 88$ & $\begin{array}{l}\text { W. G. Heath, T. J. Cox, } \\
\text { P. C. Rosen }\end{array}$ \\
\hline & $\begin{array}{l}5626,5630,5633,53164 \\
84764,84767\end{array}$ & UI & $\begin{array}{l}\text { 05/01/49, 06/10/49, 03/28/63, } \\
06 / 15 / 56\end{array}$ & $\begin{array}{l}\text { D. M. Smith, R. Brown, M. Hensley, } \\
\text { F. A. Shannon, R. Abbuhl, } \\
\text { L. Humphrey }\end{array}$ \\
\hline speckled rattlesnake & 41780,49434 & UA & $12 / 06 / 75,04 / 07 / 90$ & T. VanDevender, P. C. Rosen \\
\hline \multirow[t]{2}{*}{ black-tailed rattlesnake } & 5634 & UI & $04 / 21 / 49$ & D. M. Smith, \& M. Hensley \\
\hline & $48764 \quad-\quad \ldots$ & UA & $08 / 19 / 88$ & P.C. Rosen \\
\hline tiger rattlesnake & $\begin{array}{l}27830,47963,48605 \\
48844,50085\end{array}$ & UA & $\begin{array}{l}09 / 05 / 60,08 / 06 / 84,04 / 23 / 89 \\
08 / 03 / 89,06 / 10 / 93\end{array}$ & $\begin{array}{l}\text { J. Beatty, D. Anderson, } \\
\text { P. C. Rosen }\end{array}$ \\
\hline western rattlesnake & 3119 & NHMLAC & & \\
\hline \multirow[t]{5}{*}{ Mojave rattlesnake } & 13095 & CAS1 & $05 / 10 / 51$ & H. K. Gloyd \\
\hline & $6515,8636,8637$ & INHS & $06 / 01 / 52,07 / 27 / 57,08 / 01 / 57$ & $\begin{array}{l}\text { W. Supernaugh, P. W. Smith, } \\
\text { M. M. Hensley }\end{array}$ \\
\hline & $64282-84,105062-64$ & NHMLAC & & \\
\hline & $\begin{array}{l}27727,27759,41103 \\
42597,47890,47913 \\
47915,47925-27,47968 \\
48688,50171\end{array}$ & UA & $\begin{array}{l}05 / 26 / 56,03 / 31 / 66,06 / 12 / 50 \\
07 / 07 / 77,05 / 19 / 88,08 / 22 / 87 \\
09 / 27 / 87,10 / 04 / 87,08 / 23 / 87 \\
08 / 19 / 87,09 / 16 / 88,09 / 22 / 89 \\
04 / 12 / 93\end{array}$ & $\begin{array}{l}\text { D. D. Koehler, C. H. Lowe, } \\
\text { W. H. Woodin, J. K. Cross, } \\
\text { P. C. Rosen, E. B. Wirt, M. Daniels, } \\
\text { D. Parizek }\end{array}$ \\
\hline & $5635-37,6014,84841$ & UI & $\begin{array}{l}04 / 18 / 49,04 / 20 / 49,08 / 04 / 48 \\
06 / 15 / 57\end{array}$ & $\begin{array}{l}\text { D. M. Smith, M.M. Hensley, } \\
\text { W. L. Burger, F. A. Shannon, } \\
\text { F. L. Humphrey }\end{array}$ \\
\hline \multicolumn{5}{|l|}{ Bird } \\
\hline \multirow[t]{2}{*}{ Gambel's quail } & $64361-62$ & UCB & $01 / 26 / 34,01 / 27 / 34$ & L. Kellogg, S. H. Bowles \\
\hline & 1142 & UA & & \\
\hline rough-legged hawk & 4881 & UA & & \\
\hline common tern & $14621-22$ & UA & & \\
\hline elf owl & 10 & TCWC & $06 / 23 / 32$ & W. P. Taylor \\
\hline common poorwill & 15143,16762 & UA & & \\
\hline red-naped sapsucker & 64381 & UCB & $01 / 29 / 34$ & L. Kellogg \\
\hline gilded flicker & $64372,64367-71$ & UCB & $\begin{array}{l}02 / 1 / 34,01 / 26 / 34,01 / 29 / 34 \\
01 / 31 / 34\end{array}$ & M. M. Erickson, L. Kellogg \\
\hline Say's phoebe & 64392 & UCB & $02 / 2 / 34$ & M. M. Erickson \\
\hline ash-throated flycatcher & 64385 & UCB & $02 / 1 / 34$ & L. Kellogg \\
\hline loggerhead shrike & $64440-41$ & UCB & $01 / 27 / 34,02 / 02 / 34$ & M. M. Erickson \\
\hline verdin & 114 & TCWC & $06 / 23 / 32$ & W. P. Taylor \\
\hline \multirow[t]{2}{*}{ cactus wren } & 7503,13108 & UA & & \\
\hline & 64408,64425 & UCB & $01 / 29 / 34,01 / 26 / 34$ & M. M. Erickson, L. Kellogg \\
\hline canyon wren & $64411-16$ & UCB & $01 / 29 / 34,01 / 30 / 34,02 / 01 / 34$ & M. M. Erickson \\
\hline black-tailed gnatcatcher & 118 & TCWC & $06 / 22 / 32$ & W. P. Taylor \\
\hline northern mockingbird & $64419-20$ & UCB & $01 / 27 / 34,02 / 01 / 34$ & M. M. Erickson, L. Kellogg \\
\hline sage thrasher & $64409,64423-24,64426-27$ & UCB & $\begin{array}{l}01 / 30 / 34,01 / 24 / 34,01 / 26 / 34 \\
01 / 27 / 34\end{array}$ & M. M. Erickson, L. Kellogg \\
\hline crissal thrasher & 64421 & UCB & $02 / 2 / 19$ & L. Kellogg \\
\hline golden-winged warbler & 9371 & UA & & \\
\hline canyon towhee & 64461 & UCB & & M. M. Erickson \\
\hline white-crowned sparrow & 64469 & UCB & $01 / 27 / 34$ & L. Kellogg \\
\hline northern cardinal & 83 & TCWC & 06/23/19 & W. P. Taylor \\
\hline
\end{tabular}




\begin{tabular}{|c|c|c|c|c|}
\hline $\begin{array}{l}\text { Taxon } \\
\text { Common name } \\
\end{array}$ & Field collection number & Collection $^{\mathrm{a}}$ & Date(s) & Primary collector(s) \\
\hline \multicolumn{5}{|l|}{ Mammal } \\
\hline Crawford's desert shrew & 24508, 24600, 25332 & UA & 07/5/83, 08/07/83, 04/19/87 & $\begin{array}{l}\text { Y. Petryszyn, W. E. Hall, } \\
\text { C. A. Olsen }\end{array}$ \\
\hline California leaf-nosed bat & $23779,23931-32$ & UA & $07 / 8 / 79,02 / 24 / 79$ & Y. Petryszyn, R. A. Gerhart \\
\hline southern long-nosed bat & $\begin{array}{l}23780,23778,23899 \\
23901,24452,26073\end{array}$ & UA & $\begin{array}{l}07 / 08 / 79,07 / 09 / 79,07 / 31 / 79 \\
07 / 28 / 79,04 / 24 / 82,10 / 1 / 82\end{array}$ & Y. Petryszyn, J. W. Steiger \\
\hline cave myotis & $23784-85,25973$ & UA & $07 / 8 / 79,09 / 08 / 93$ & Y. Petryszyn \\
\hline \multirow[t]{2}{*}{ California myotis } & 183586 & UCB & $01 / 26 / 45$ & D. G. Constantine \\
\hline & $23745,23776-77,26220$ & UA & $\begin{array}{l}07 / 31 / 79,07 / 08 / 79,07 / 09 / 79 \\
07 / 12 / 89\end{array}$ & J. W. Steiger, Y. Petryszyn \\
\hline \multirow[t]{2}{*}{ western pipistrelle } & 61933 & UCB & $02 / 2 / 34$ & M. M. Erickson \\
\hline & $\begin{array}{l}23782-83,24320,24444, \\
24483,25976,26061\end{array}$ & UA & $\begin{array}{l}07 / 8 / 79,05 / 31 / 79,10 / 26 / 81 \\
09 / 26 / 81,04 / 23 / 82,09 / 07 / 93\end{array}$ & $\begin{array}{l}\text { Y. Petryszyn, L. L. Zaffino, } \\
\text { M. T. Brown }\end{array}$ \\
\hline big brown bat & $\begin{array}{l}23746-48,23900,23902, \\
23982,24442,24482\end{array}$ & UA & $\begin{array}{l}03 / 31 / 79,07 / 28 / 79,07 / 08 / 79 \\
09 / 14 / 79,09 / 26 / 81,04 / 23 / 82\end{array}$ & $\begin{array}{l}\text { R. A. Gerhart, J. W. Steiger, } \\
\text { Y. Petryszyn, M. T. Brown }\end{array}$ \\
\hline hoary bat & 23981 & UA & $09 / 15 / 79$ & Y. Petryszyn \\
\hline Townsend's big-eared bat & 183618 & UCB & $06 / 29 / 45$ & D. G. Constantine \\
\hline pallid bat & $23933-34,24504$ & UA & $03 / 31 / 79,04 / 24 / 82$ & R. A. Gerhart, Y. Petryszyn \\
\hline pocketed free-tailed bat & $\begin{array}{l}23979-80,24443,24453 \\
24594,24608-09,24612 \\
24783-84\end{array}$ & UA & $\begin{array}{l}\text { 05/31/79, 09/14/79, 09/26/81, } \\
\text { 06/24/82, 09/27/81, 06/18/83, } \\
06 / 15 / 83\end{array}$ & $\begin{array}{l}\text { L. L. Zaffino, Y. Petryszyn, } \\
\text { M. T. Brown, R. Agte, E. Bernstein, } \\
\text { J. Pickrel }\end{array}$ \\
\hline western bonneted bat & 26209 & UA & $02 / 2 / 95$ & Y. Petryszyn \\
\hline Underwood's bonneted bat & $\begin{array}{l}23990,24321-22,24441, \\
24454,24593\end{array}$ & UA & $\begin{array}{l}09 / 14 / 79,10 / 26 / 81,06 / 24 / 82 \\
01 / 07 / 83,06 / 18 / 83\end{array}$ & J. W. Steiger, Y. Petryszyn \\
\hline American badger & 25508 & UA & $10 / 24 / 90$ & K. A. Jarik \\
\hline feral dog & 25359 & UA & $06 / 20 / 88$ & S. Russel, Y. Petryszyn \\
\hline coyote & $61949-51$ & UCB & $02 / 01 / 34,01 / 25 / 34,01 / 26 / 34$ & L. Kellogg, M. M. Erickson \\
\hline kit fox & 25358 & UA & $09 / 23 / 88$ & S. Russel, Y. Petryszyn \\
\hline \multirow[t]{2}{*}{ common gray fox } & $61947-48$ & UCB & $02 / 02 / 34,01 / 26 / 34$ & A. M. Alexander \\
\hline & 25357 & UA & $06 / 01 / 1983$ & R. Bowers \\
\hline \multirow[t]{3}{*}{ round-tailed ground squirrel } & $149819-23$ & UK & $7 / 18 / 50,07 / 19 / 50,07 / 20 / 50$ & A. Schwartz \\
\hline & $61953-60$ & UCB & $01 / 28 / 34,01 / 29 / 34$ & L. Kellogg, A. M. Alexander \\
\hline & $29451-52$ & TCWC & $06 / 24 / 32$ & W. P. Taylor \\
\hline \multirow[t]{3}{*}{ Harris' antelope squirrel } & $149413-16$ & UK & $07 / 19 / 50,07 / 20 / 50$ & A. Schwartz \\
\hline & $61975-77$ & UCB & $01 / 30 / 34,01 / 31 / 34,01 / 25 / 34$ & L. Kellogg, M. M. Erickson \\
\hline & $24582,24948,24994$ & UA & $10 / 03 / 1981$ & G. Webb, A. May, D. Sutton \\
\hline Botta's pocket gopher & $\begin{array}{l}62142,62148-53,62157 \\
62140-41,62143-47 \\
62154-56\end{array}$ & UCB & $\begin{array}{l}01 / 30 / 34,01 / 31 / 34,02 / 01 / 34 \\
01 / 29 / 34\end{array}$ & M. M. Erickson, L. Kellogg \\
\hline \multirow[t]{2}{*}{ Arizona pocket mouse } & $149349-51$ & UK & $07 / 19 / 50,08 / 23 / 54$ & A. Schwartz \\
\hline & $\begin{array}{l}17768,24571,24771, \\
24827-28,24854,24855, \\
24858-60,24962,24995, \\
26292\end{array}$ & UA & $\begin{array}{l}07 / 29 / 68,10 / 04 / 81,10 / 03 / 82 \\
09 / 23 / 83,10 / 02 / 82,09 / 25 / 83 \\
09 / 24 / 83,09 / 22 / 84\end{array}$ & $\begin{array}{l}\text { J. M. Mondean, S. Seidler, } \\
\text { P. Holm, J. Morganflash, P. Casey, } \\
\text { A. Wigg, K. Blum, J. E. McKendy, } \\
\text { D. V. Smith, C. Bernstein, L. Kervin }\end{array}$ \\
\hline little pocket mouse & $24730-31$ & UA & $10 / 07 / 83,09 / 25 / 83$ & Y. Petryszyn, D. V. Smith \\
\hline
\end{tabular}




\begin{tabular}{|c|c|c|c|c|}
\hline $\begin{array}{l}\text { Taxon } \\
\text { Common name }\end{array}$ & Field collection number & Collection $^{\mathrm{a}}$ & Date(s) & Primary collector(s) \\
\hline \multicolumn{5}{|l|}{ Mammal } \\
\hline $\begin{array}{l}\text { Sonoran Desert pocket } \\
\text { mouse }\end{array}$ & $\begin{array}{l}17769,24484,24644, \\
24647-48,24773,24865-66, \\
24919-20,24956-59, \\
24991-93,25014-17,25030, \\
25034-35,25138,25143, \\
25217,25232,26310-11, \\
26404\end{array}$ & UA & $\begin{array}{l}07 / 29 / 68,09 / 26 / 81,09 / 27 / 81 \\
09 / 25 / 82,10 / 04 / 81,10 / 03 / 81 \\
\text { 10/02/82, 10/03/82, 09/23/83, } \\
09 / 24 / 82,09 / 25 / 83,09 / 24 / 83 \\
05 / 17 / 82,09 / 23 / 84,10 / 02 / 82, \\
10 / 01 / 84\end{array}$ & $\begin{array}{l}\text { S. D. Koerner, S. M. Russell, } \\
\text { K. Kingsley, G. Webb, G. Delfrate, } \\
\text { K. Blum, L. J. Risan, J. A. } \\
\text { Mazzolini, K. E. Comstock, } \\
\text { S. Seidler, A. J. Wigg, L. A. Weeks, } \\
\text { M. J. Hazlett, B. Standley, } \\
\text { K. Yamaguchi, J. E. McKendy, } \\
\text { K. L. Madariaga, D. V. Smith, R. L. } \\
\text { Moyer, C. H. Behrens, P. A. Holms, } \\
\text { K. J. Stenberg, M. Rome, } \\
\text { D. Duncan, R. Agte }\end{array}$ \\
\hline \multirow[t]{3}{*}{ rock pocket mouse } & $62250-68$ & UCB & $\begin{array}{l}\text { 01/29/34, 01/31/34, 02/01/34, } \\
02 / 02 / 34,02 / 03 / 34\end{array}$ & A. M. Alexander, L. Kellogg \\
\hline & 29444 & TCWC & $06 / 24 / 32$ & W. P. Taylor \\
\hline & $\begin{array}{l}24487,24627-28,24733, \\
24799-800,24829,24867, \\
24903,24918,24987-90, \\
25022-26,25039,25040-42, \\
25137,25140-42,25144\end{array}$ & UA & $\begin{array}{l}04 / 23 / 82,10 / 03 / 81,09 / 25 / 81 \\
10 / 03 / 82,09 / 23 / 83,09 / 24 / 83 \\
09 / 25 / 82,10 / 04 / 81,09 / 27 / 81 \\
10 / 01 / 82,09 / 25 / 83,09 / 26 / 81\end{array}$ & $\begin{array}{l}\text { Y. Petryszyn, P. Holm, E. Sterling, } \\
\text { K. Flanagan, D. Youkey, } \\
\text { E. Moonga, P. Casey, L. J. } \\
\text { Risan, A. Massolini, D. Stanley, } \\
\text { A. Wigg, J. Cole, L. A. Weeks, } \\
\text { K. R. Blum, R. L. Moyer, D. J. } \\
\text { Hansen, K. Yamaguchi, J. Hazam, } \\
\text { C. H. Behrans, J. M. Herron }\end{array}$ \\
\hline Bailey's pocket mouse & $\begin{array}{l}24503,24572-77, \\
24629-33,24639-40,24643, \\
24769-70,25031-33, \\
25036-37,25046-57, \\
25059-60,25064-69, \\
25116-36,25156,25158, \\
26412\end{array}$ & UA & $\begin{array}{l}\text { 09/26/81, 10/03/81, 09/27/81, } \\
08 / 26 / 81,10 / 04 / 81,09 / 25 / 81\end{array}$ & $\begin{array}{l}\text { C. Szuter, G. Delfrate, P. Raimondi, } \\
\text { G. Webb, R. Collins, P. S. Sutton, } \\
\text { L. A. Weeks, J. A. Mazzolini, S. J. } \\
\text { Fedorko, R. R. Jones, M. J. } \\
\text { Hazlett, K. E. Comstock, D. J. } \\
\text { Hansen, J. Cole, D. A. Stanley, } \\
\text { R. Day, C. H. Behrens, E. Thoms, } \\
\text { P. A. McGrath, S. Kohnke, E. G. } \\
\text { Morrow, J. Cooley, R. Byers, } \\
\text { M. T. Brown, R. Agte }\end{array}$ \\
\hline \multirow[t]{2}{*}{ desert kangaroo rat } & $62382-83$ & UCB & $1 / 30 / 34,01 / 31 / 34$ & A. M. Alexander \\
\hline & 24658,24768 & UA & $09 / 24 / 83,10 / 02 / 81$ & B. Standley, L. Weeks \\
\hline banner-tailed kangaroo rat & $149338-41$ & UK & $07 / 17 / 50$ & A. Schwartz \\
\hline \multirow[t]{3}{*}{ Merriam's kangaroo rat } & $149220-21,149223-29$ & UK & $07 / 18 / 50,07 / 19 / 50$ & A. Schwartz \\
\hline & $62363-68,62372-77$ & UCB & $\begin{array}{l}01 / 30 / 34,01 / 29 / 34,02 / 03 / 34 \\
01 / 26 / 34,01 / 24 / 34\end{array}$ & M. M. Erickson, A. M. Alexander \\
\hline & $\begin{array}{l}\text { 17767, 24564-68, } \\
\text { 24615-17, 24620, 24624-26, } \\
\text { 24767, 24804-05, 24807, } \\
\text { 24825-26, 24841, 24843-47, } \\
\text { 24852-53, 24923-37, } \\
\text { 24963-71, 24978, 24980, } \\
24997-002,25004-13, \\
\text { 25018-20, 25043-45, } \\
25077-84,25086-115, \\
25139,25146-150,25153, \\
25155,25198,25712, \\
26091,26143,25153, \\
25155,25198,25712, \\
26091,26143,26145,26146, \\
26226,26254-55,26273, \\
26290-91,26321,26370\end{array}$ & UA & $\begin{array}{l}07 / 29 / 68,10 / 03 / 81,10 / 02 / 81 \\
10 / 04 / 81,09 / 27 / 81,10 / 02 / 82, \\
09 / 25 / 82,10 / 08 / 83,10 / 03 / 82, \\
10 / 01 / 82,10 / 02 / 82,09 / 26 / 82, \\
08 / 26 / 82,09 / 24 / 82,10 / 09 / 81, \\
11 / 21 / 82\end{array}$ & $\begin{array}{l}\text { S. Black, S. Seidler, G. Delfrate, } \\
\text { L. Weeks, C. Lindquist, J. Hazain, } \\
\text { J. Bates, A. May, D. Cralmer, } \\
\text { P. Holm, E. A. Sterling, D. Hansen, } \\
\text { P. S. Sutton, S. J. Fedorko, } \\
\text { R. Jones, J. E. McKendry, } \\
\text { N. Mays, D. Callison, M. J. Hazlett, } \\
\text { G. W. Parry, S. A. Carroll, K. R. } \\
\text { Blum, A. J. Wigg, K. O. Moyers, } \\
\text { B. G. Nidetz, D. K. Duncan, } \\
\text { R. Byers, K. L. Madariaga, } \\
\text { E. Melink, M. J. Podborag, R. R. } \\
\text { Jones, K. M. Flanagan, D. Stejskal, } \\
\text { J. Buchanan, M. Bernas, J. Herron, } \\
\text { R. Buyers, J. Cole, G. Montgomery, } \\
\text { J. Brown, L. J. Risen }\end{array}$ \\
\hline
\end{tabular}




\begin{tabular}{|c|c|c|c|c|}
\hline $\begin{array}{l}\text { Taxon } \\
\text { Common name } \\
\end{array}$ & Field collection number & Collection $^{\mathrm{a}}$ & Date(s) & Primary collector(s) \\
\hline \multicolumn{5}{|l|}{ Mammal } \\
\hline \multirow[t]{2}{*}{ cactus mouse } & $62491-508$ & UCB & $\begin{array}{l}01 / 29 / 34,01 / 30 / 34,01 / 31 / 34 \\
02 / 01 / 34,02 / 03 / 34,01 / 03 / 34, \\
01 / 24 / 24,01 / 25 / 34\end{array}$ & $\begin{array}{l}\text { L. Kellogg, A. M. Alexander, } \\
\text { M. M. Erickson }\end{array}$ \\
\hline & $\begin{array}{l}24445,24484-86,24492, \\
24809-11,24943-47, \\
24996,25145,25157, \\
25789,26289\end{array}$ & UA & $\begin{array}{l}\text { 09/26/81, 04/23/82, 11/19/81, } \\
\text { 09/24/83, 09/25/83, 09/23/83, } \\
\text { 09/27/81, 10/04/81, 04/25/82, } \\
\text { 05/14/82 }\end{array}$ & $\begin{array}{l}\text { M. T. Brown, Y. Petryszyn, } \\
\text { R. Collins, C. Bernstein, D. Youkey, } \\
\text { R. L. Moyer, K. E. Comstock, } \\
\text { J. Bates, R. R. Jones, P. McGrath, } \\
\text { M. Hazlett, J. V. Salmon }\end{array}$ \\
\hline black-eared mouse & 24817 & UA & $10 / 28 / 83$ & B. Standley \\
\hline Merriam's mouse & 25494 & UA & $12 / 7 / 88$ & Y. Petryszyn \\
\hline \multirow[t]{2}{*}{$\begin{array}{l}\text { western white-throated } \\
\text { woodrat }\end{array}$} & $62631-45,182894$ & UCB & $\begin{array}{l}\text { 01/24/34, 01/25/34, 01/30/34, } \\
01 / 31 / 34\end{array}$ & $\begin{array}{l}\text { A. M. Alexander, L. Kellogg, } \\
\text { M. M. Erickson }\end{array}$ \\
\hline & $\begin{array}{l}24649-50,24842,24864, \\
24938-42,24949-55, \\
24972,24981-86,25038, \\
25070-76,25151-52\end{array}$ & UA & $\begin{array}{l}\text { 09/27/81, 11/21/82, 09/25/82, } \\
04 / 25 / 82,09 / 23 / 83,09 / 24 / 83, \\
\text { 10/03/82, 10/01/82, 04/26/82, } \\
\text { 10/04/81, 09/26/81, 10/03/81, } \\
\text { 09/25/81 }\end{array}$ & $\begin{array}{l}\text { G. Webb, G. Delfrate, A. May, } \\
\text { R. K. Bowers, M. Hazlett, } \\
\text { D. Youkey, B. Standley, J. Hazarn, } \\
\text { J. McKendy, S. Seidler, R. R. } \\
\text { Jones, J. M. Bates, M. T. Brown, } \\
\text { R. L. Moyer, R. Day, P. McGrath, } \\
\text { L. A. Weeks, D. A. Stanley, D. J. } \\
\text { Stejskal, J. S. Buchanon, K. E. } \\
\text { Comstock, D. J. Hansen }\end{array}$ \\
\hline Arizona cotton rat & 25871 & UA & $06 / 30 / 92$ & Y. Petryszyn \\
\hline desert bighorn sheep & 25528 & UA & $04 / 14 / 91$ & P. Fernandez, P. Rosen \\
\hline
\end{tabular}

${ }^{a}$ BYU = Brigham Young University; CAS = California Academy of Science; CAS1 = Chicago Academy of Sciences;

FWMSH = Fort Worth Museum of Science and History; Har = Museum of Comparitive Zoology, Harvard University;

INHS = Illinois Natural History Survey; MSU = Michigan State University; NHMLAC = Natural History Museum of Los Angeles County;

TCWC = Texas Cooperative Wildlife Collection; TMNH = Tulane Museum of Natural History; UC = University of Colorado Museum,

$\mathrm{UCB}=$ Museum of Vertebrate Zoology, University of California, Berkeley; UI = University of Illinois, Museum of Natural History;

UK = Museum of Natural History, University of Kansas; UM = University of Michigan; USNM = U. S. National Museum;

UTEP = University of Texas, EI Paso. 
